\title{
Prospective development of extracorporeal life support: from protoscience to science
}

Citation for published version (APA):

Ganushchak, Y. M. (2013). Prospective development of extracorporeal life support: from protoscience to science. [Doctoral Thesis, Maastricht University]. Datawyse / Universitaire Pers Maastricht. https://doi.org/10.26481/dis.20131211yg

Document status and date:

Published: 01/01/2013

DOI:

10.26481/dis.20131211yg

Document Version:

Publisher's PDF, also known as Version of record

\section{Please check the document version of this publication:}

- A submitted manuscript is the version of the article upon submission and before peer-review. There can be important differences between the submitted version and the official published version of record.

People interested in the research are advised to contact the author for the final version of the publication, or visit the DOI to the publisher's website.

- The final author version and the galley proof are versions of the publication after peer review.

- The final published version features the final layout of the paper including the volume, issue and page numbers.

Link to publication

\footnotetext{
General rights rights.

- You may freely distribute the URL identifying the publication in the public portal. please follow below link for the End User Agreement:

www.umlib.nl/taverne-license

Take down policy

If you believe that this document breaches copyright please contact us at:

repository@maastrichtuniversity.nl

providing details and we will investigate your claim.
}

Copyright and moral rights for the publications made accessible in the public portal are retained by the authors and/or other copyright owners and it is a condition of accessing publications that users recognise and abide by the legal requirements associated with these

- Users may download and print one copy of any publication from the public portal for the purpose of private study or research.

- You may not further distribute the material or use it for any profit-making activity or commercial gain

If the publication is distributed under the terms of Article $25 \mathrm{fa}$ of the Dutch Copyright Act, indicated by the "Taverne" license above, 
Prospective development of extracorporeal life support from protoscience to science 
The author appreciates financial support for his dissertation.

Major financial support was granted by Maquet Netherlands BV.

Additional financial support was established by Edwards Lifesciences BV, Krijnen Medical Innovations BV, Laguna Health BV, QP\&S NV, Sorin Group Nederland NV, Terumo Europe NV and Transonic Systems Inc.

Financial support by Stichting Hartsvrienden RESCAR for publication of this thesis is gratefully acknowledged.

(C) Copyright YM Ganushchak, Maastricht 2013

ISBN 9789461592873

Datawyse / Universitaire Pers Maastricht 


\title{
Prospective development of extracorporeal life support from protoscience to science
}

\author{
PROEFSCHRIFT \\ ter verkrijging van de graad van doctor aan de Universiteit Maastricht, \\ op gezag van de Rector Magnificus, Prof. dr. L.L.G. Soete \\ volgens het besluit van het College van Decanen, \\ in het openbaar te verdedigen \\ op woensdag 11 december 2013 om 14:00 uur \\ door
}

Yuri M. Ganushchak

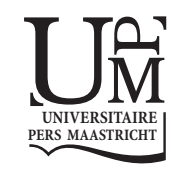




\section{Promotor}

Prof. dr. J.G. Maessen

\section{Copromotores}

Dr. P.W. Weerwind

\section{Beoordelingscommissie}

Prof. dr. W.F.F.A. Buhre (voorzitter)

Prof. dr.J. Bělohlávek, (General Teaching Hospital, Charles University in Prague)

Prof. dr. W. H. Mess

Prof. dr. P.M.H.T. Roekaerts 
"Not only life might thus be kept up both in the head and in any other portion separated from the body of an animal, but it might also be re-produced after its entire extinction. It might be restored likewise to the whole body, and thereby a complete resurrection be performed in the full extent of the word."

JJC Le Gallois, Experiences in the Principle of Life, 1813. 



\section{Contents}

Foreword 99

Chapter 1 Introduction 'A glance to the future' 11

$\begin{array}{ll}\text { Outline of this thesis } & 17\end{array}$

Chapter 2 Neurological complications after coronary artery bypass grafting related 19 to the performance of cardiopulmonary bypass

Chapter 3 The oxygen debt during routine cardiac surgery: illusion or reality? 39

Chapter 4 The effect of oxygenator mechanical characteristics on energy transfer 55 during clinical cardiopulmonary bypass

Chapter 5 Hydrodynamic performance and heat generation by centrifugal pumps

Chapter 6 Can minimized cardiopulmonary bypass systems be safer?

Chapter 7 General discussion

Summary

Samenvatting

Резюме

Acknowledgments

Curriculum vitae 



\section{Foreword}

More than thirty years ago, when I just had started the training in extracorporeal life support technology the disc oxygenators where still in use. The most dramatic and somewhere devastating effect of these decades of clinical experience with heart-lung machine is described best by the words of Dr. Denton Cooley "At that time I developed an impression, which has lasted through almost my whole career, that the important thing in cardiopulmonary bypass was to get the patient the hell off the pump as soon as possible." This idea of innate evil of cardiopulmonary bypass (extracorporeal life support) persists even now, after 10-15 years of development of new technologies. However, nowadays extracorporeal life support possessed numerous tools and methods. These allow specialists to choose the best possible individualized handling of each patient. But, on other hand such widening of possibilities requires not only deep theoretical knowledge, but also continuous analysis and systematization of practical experience.

The view at the possible gemmating of extracorporeal technology as an independent interdisciplinary science is described in the editorial 'A glance to the future' and presented as introduction of this thesis.

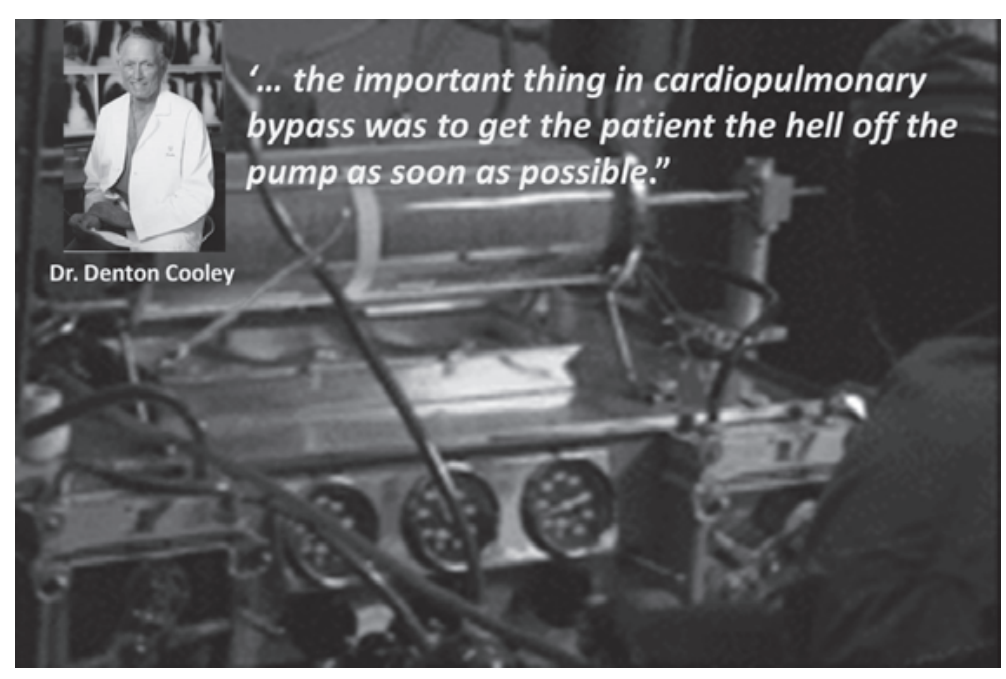





\section{CHAPTER 1}

\section{Introduction 'A glance to the future'}

YM Ganushchak, PW Weerwind and JG Maessen

Published as an Editorial in: Perfusion 2012; 27:95-96. 
CHAPTER 1 
The editorial 'Why look backwards?' by Mark Kurusz [1] can be seen as a landmark that summarizes the human dimension of more than a half-century history of extracorporeal life support. Extracorporeal life support has made a quantum leap during the last two decades. Development of safer extracorporeal technology stimulated the spread of cardiac surgical procedures throughout the world, as well as the development of new surgical methods, widened the types of treated pathology, and extended the age limits of patients treated. One of the powerful stimuli in the explosive innovation in extracorporeal technology was the re-introduction of 'offpump' coronary bypass surgery in the early 1990s. Promising results of the first two large series on 'off-pump' coronary bypass surgery, economic reasons [2,3], and the interest in minimally invasive coronary surgery through mini-thoracotomy approaches as well, encouraged the adoption of this technique throughout the world [4]. The decreasing demand for cardiopulmonary bypass procedures with the wide use of 'offpump' methods acted as a stimulus for inventions such as new blood-surface coatings, resulting in more efficient and biocompatible oxygenators and systems. Blood-saving methods and techniques for preventing haemodilution were developed and found recognition worldwide during this period as well. Moreover, enhanced biocompatibility and robust extracorporeal equipment (re-)opened exceptionally wide horizons for extracorporeal life support in intensive care therapy, resuscitation, oncology, organ preservation, and invasive cardiology, in addition to traditional applications in cardiac and vascular surgery.

Despite tremendous progress in equipment and the expanding areas where the methods of extracorporeal life support are applicable, the structure of the profession, as well as the theory behind extracorporeal life support, is now just making the first uncertain steps from the primary seas of protoscience to the shore sands of established and well-respected science. Science as a systematic enterprise that builds and organizes knowledge in the form of testable explanations and predictions definitely exists in extracorporeal life support methodology. However, still, even the everyday routine cardiopulmonary bypass procedure for cardiac surgery demands not only broad knowledge, but also 'hands-on' experience, fast deductive reasoning and, in part, something indefinable. Patient survival is often determined in the minutes it takes for cellular death to occur due to ischemia. So, it is a one shot deal, without any chance for replay. In other words, a perfusionist must provide mastery to even routine cardiopulmonary bypass to bring about a satisfactory outcome. A gigantic divergence between the newest highly sophisticated equipment, fast expansion in new fields of activities, and limited understanding of involved processes attracts and demands more and more attention today $[5,6]$.

The sometimes 'lagging behind' in perfusion technology can be related to the relatively late germination of technology and sometimes feigned absence of a niche in 
an academic level of the medical science structure. However, the interdisciplinary nature of required knowledge and, inherent with this, obstacles in formation and development of science are most important. Perfusion technology or, as more commonly used by most authors and clinicians, cardiovascular perfusion, can be defined as a profession that combines technical expertise and medical knowledge [5]. Despite the apparent simplicity of this definition, it demonstrates the necessity of assimilating knowledge across a wide range of scientific specialties, encompassing, among others, biology, physiology, pathophysiology, biochemistry, physics, bioengineering, and medical science. The interdisciplinary nature of this emerging profession is reflected in a wide diversity of required backgrounds of new recruits. The task of the new generation is not simpler than the task of the pioneers. This task is to melt diverse ingots of knowledge from a wide range of academic fields into a single discipline.

It is absolutely right that the 'war stories' of the first generation become historical footnotes with development of new technologies and extensive accumulation and sharing of experience and knowledge. However, what we cannot forget, put into footnotes, are the spirit, good will, and dedication of the pioneers. We must preserve and foster their devotion to the coming generations. 


\section{References}

1. Kurusz M. Why look backwards? Perfusion 2011; 26:357.

2. Benetti FJ, Naselli G, Wood M, et al. Direct myocardial revascularization without extracorporeal circulation. Experience in 700 patients. Chest 1991; 100:312-316.

3. Buffolo $\mathrm{E}$, de Andrade CS, Branco JN, et al. Coronary artery bypass grafting without cardiopulmonary bypass. Ann Thorac Surg 1996; 61:63-66.

4. Ascione R, Angelini GD. OPCAB surgery: a voyage of discovery back to the future. Off-pump coronary artery bypass. Eur Heart J 2003; 24:121-124.

5. Merkle F. From pump technicians to qualified health personnel--the evolution of the perfusionist profession. Interact Cardiovasc Thorac Surg 2010; 10:496-497.

6. Beckmann A, Benk C, Beyersdorf F, et al. Position article for the use of extracorporeal life support in adult patients. Eur J Cardiothorac Surg 2011; 40:676-680. 



\section{Outline of this thesis}

This dissertation presents a collection of studies that illustrates a first effort of "consilience" of several branches of physical sciences as well as life sciences. The following chapters outline the boundaries, present examples of investigation methods, and mark the frontier areas where the expertise of the clinical perfusionist is required.

Chapter 2 a retrospective study on neurological complications after coronary artery bypass grafting is used as an example of a possible way to distinguish extracorporeal life support related factors (or combinations of factors), which influenced the outcome of surgery. The use of clinical endpoints in investigation of extracorporeal life support was demonstrated. Additionally, a method for the analysis of the required enormous amount of data was presented.

Chapter $\mathbf{3}$ is dedicated to the two fundamental aspects of cardiopulmonary bypass. First, the relation between oxygen consumption and oxygen delivery during cardiopulmonary bypass was described. These parameters and their relation where used as a complex surrogate end point of a prospective clinical study. Second, the 'individual reference values' of these parameters for an extracorporeal life support procedure were defined. This latter aspect is of great importance, both for practical and for theoretical development of the profession.

Chapter 4 focuses on the keystone of extracorporeal life support, i.e. the understanding that during cardiopulmonary bypass 'patient-heart-lung machine' is a one-piece system. Another very important message of this chapter is the necessity to use clear quantitative terms in description of this system. The effect of oxygenator mechanical characteristics on energy transfer during clinical cardiopulmonary bypass demonstrates how individual components of the cardiopulmonary bypass system affect created flow and energy.

Chapter 5 demonstrates the necessity of technical knowledge and understanding of processes involved in everyday practice, focusing on centrifugal blood pumps. 
Chapter 6 deals with the development of new, low volume systems for extracorporeal life support during cardiac surgery procedures, particularly the safety of these socalled mini-systems. The use of combination of clinical findings and experimental as expansion and explanation of study results was demonstrated in this study.

Chapter $\mathbf{7}$ is the general discussion where the main subject of extracorporeal life technology as an interdisciplinary science was defined as an integral heart-lung machine - patient system with unique, specific relations and reference values. Herewith optimal practice in management of extracorporeal life support is the careful, forthcoming balance between individual patient's requirements and limitations. 


\section{CHAPTER 2}

\section{Neurological complications after coronary artery bypass grafting related to the performance of cardiopulmonary bypass}

YM Ganushchak, EJ Fransen, C Visser, DS de Jong, and JG Maessen

Published in Chest 2004; 1256:2196-2205. 


\section{Abstract}

Study objectives: Neurologic disorders belong among the most serious complications of cardiac surgery. We tested the hypothesis that combinations of hemodynamic events from apparently normal cardiopulmonary bypass (CPB) procedures are related to the development of postoperative neurologic complications and affect the impact of common clinical risk factors.

Design: Retrospective study.

Setting: Cardiothoracic surgery department in a university hospital.

Methods and patients: A multivariate statistical procedure (i.e., cluster analysis) was applied to a data set of automatically recorded perfusions from 1,395 patients who had undergone coronary artery bypass grafting. One-way analysis of variance was used to select five parameters with the strongest significant correlation to postoperative neurologic complications for further cluster analysis. The dependencies in the clusters were tested against common clinical risk factors. To our knowledge, this is the first study of its kind.

Results: The following five parameters emerged for cluster analysis: mean arterial pressure (MAP); dispersion of MAP; dispersion of systemic vascular resistance; dispersion of arterial pulse pressure; and the maximum value of mixed venous saturation. Using these parameters, we found four clusters that were significantly different by CPB performance (first cluster, 389 patients; second cluster, 431 patients; third cluster; and fourth cluster, 229 patients). The frequency of postoperative neurologic complications was $0.3 \%$ in the first cluster and increased to $3.9 \%$ in the fourth cluster. Importantly, the impact of common clinical risk factors for postoperative neurologic complications was affected by the performance of the CPB procedure. For example, the frequency of neurologic complications among patients with cerebrovascular disease in their medical history was $22 \%$ in the fourth cluster, whereas it was zero in the second cluster.

Conclusions: This study shows that apparently normal CPB procedures affect the impact of common clinical risk factors on postoperative neurologic complications. Patients who underwent CPB procedures with large fluctuations in hemodynamic parameters particularly showed an increased risk for the development of postoperative neurologic complications. 


\section{Introduction}

CNS disorders after coronary artery bypass grafting (CABG) significantly increase perioperative mortality and hospitalization time, and can lead to a decrease in the patient's quality of life. The reported rate of major postoperative neurologic complications, such as stroke, varies from 0.8 to $6 \%$ [1-4]. Mechanisms causing these complications are not well understood. Previous studies have focused primarily on the separate identification of demographic and medical risk factors. A number of risk factors thus have been identified (e.g., age, female sex, cranio-cervical and aortic atherosclerosis, previous cerebral stroke, hypertension, duration of the operation and cardiopulmonary bypass (CPB), use of the intra-aortic balloon pump, and postoperative cardiac arrhythmias) [2-7]. As to the intraoperative factors, neurologic complications after cardiac operations have been attributed mainly to the effects of CPB [8]. Reported potential mechanisms are the microembolization and macroembolization of gas, particle matter, and inadequate cerebral perfusion pressure or flow. However, studies on the impact of conventional, uncomplicated CPB are rare and usually are performed on small, selected groups of patients. Furthermore, the multifactorial nature of neurologic dysfunction after CPB makes the results of such investigations controversial.

We undertook this retrospective study to deter mine which combination of preoperative and intra- operative risk factors, including the characteristics of $\mathrm{CPB}$, might predispose CABG patients to neurologic complications following surgery. The use of a fully automated system of perfusion record keeping provided continuous data and eliminated the possible bias that is inherent to manual record entry. Groups of patients with similar perfusion characteristics were separated by means of cluster analysis to study the interaction between the characteristics of CPB and common clinical risk factors. To our knowledge, this is the first study of its kind.

\section{Materials and Methods}

\section{Patients}

Retrospectively, 1,408 isolated CABG operations that had been carried out between May 1996 and January 1999 in the University Hospital Maastricht were reviewed. Patients with incomplete intraoperative or postoperative data were excluded from study. 


\section{Intraoperative Patient Management}

The conduct of anesthesia and CPB was standardized by hospital practice. Anesthesia was induced with midazolam ( 0.06 to $0.08 \mathrm{mg} / \mathrm{kg}$ ), sufentanil (1 to $1.5 \mu \mathrm{g} / \mathrm{kg}$ ), and pavulon $(0.1 \mathrm{mg} / \mathrm{kg})$, and was maintained with sufentanyl $(0.5$ to $1.25 \mu \mathrm{g} / \mathrm{kg} / \mathrm{h})$ and/or propofol infusion ( 3 to $6 \mathrm{mg} / \mathrm{kg} / \mathrm{h}$ ). The bypass circuit consisted of a hollow fiber oxygenator (Univox-IC; Bentley/ Baxter; Irvine, CA; or Capiox SX; Terumo Corporation; Tokyo, Japan), an arterial line filter (Pall Autovent-SV; Pall Biomedical Ltd; Portsmouth, UK), and a roller pump (Stöckert Instrumente $\mathrm{GmbH}$; Munich, Germany). The circuit was primed with a mixture of colloidal intravenous infusion solution (Haemaccel; Beacon Pharmaceuticals; Tunbridge Wells, UK) (3.5\%; 1,200 to 1,300 mL), mannitol ( $20 \%$ solution; $200 \mathrm{~mL}$ ), human albumin (20\%; $100 \mathrm{~mL}$ ), NaHCO3 $(8.4 \% ; 50 \mathrm{~mL}$ ), potassium chloride $(20 \mathrm{mmol})$, and heparin $(50 \mathrm{mg} / 1,000 \mathrm{~mL}$ colloidal intravenous infusion solution). CPB was carried out by means of pulsatile flow with a flow range of approximately $2.4 \mathrm{~L} / \mathrm{min} / \mathrm{m} 2$. Moderate hypothermia (i.e., temperature, $28^{\circ} \mathrm{C}$ to $32^{\circ} \mathrm{C}$ ) was applied during the CPB. A modified St. Thomas solution was used to arrest the heart and to maintain it in an isoelectric state. After the release of the aortic clamp, a nitroglycerine infusion $(0.5 \mu \mathrm{g} / \mathrm{kg} / \mathrm{min})$ was started.

\section{Data Collection}

All demographic and clinical data were stored in using a software program (Summit Medical Systems; Minneapolis, MN).

Postoperative neurologic complications were defined as follows: permanent or transient central neurologic deficit; mental disturbance marked by illusions, confusion, and cerebral excitement; and unresponsive coma for $>24 \mathrm{~h}$. In all cases, patients with possible neurologic complications were investigated by a neurologist. This as well as other definitions for clinical parameters was derived from the terms of the Society of Thoracic Surgeons National Cardiac Surgery Database (Table 1).

In 1996, the department of Extra-Corporeal Circulation introduced a computer program (homemade) for the continuous registration of perfusion parameters. Routinely, every $6 \mathrm{~s}, 21$ parameters of CPB are read and stored in a data file. For the present study, the following parameters were extracted from the perfusion database: mean arterial pressure (MAP); arterial pulse pressure $\left(\mathrm{AP}_{\text {pulse }}\right)$; blood flow index (BFI); systemic vascular resistance (SVR); arterial blood temperature; rectal temperature; $\mathrm{PaO}_{2}$; and mixed venous saturation $\left(\mathrm{SvO}_{2}\right)$. Also the duration of full extracorporeal circulatory support (i.e., aortic cross-clamp period or full bypass) was included in the analysis. Continuous perfusion parameters from each single CPB procedure were included in the study as their mean, maximum, and minimum values during each single 
procedure. As a degree of the scattering of data, we also included a variable that we called dispersion. Dispersion is a measure that points out how often and how far the values of the included parameters changed through the full period of CPB for each single procedure. Thus, continuous parameters in our study were presented by their four properties, as follows: mean; dispersion; maximum; and minimum.

Table 1-Demographic and Clinical Variables*

Variables

Age

Hypertension

Carotid vascular disease

Diabetes mellitus

Overweight

Perioperative myocardial infarction

Postoperative cardiac arrhythmia

Postoperative neurologic complications

Postoperative renal failure

Preoperative LVEF

Previous cerebral incident

Prior cardiac surgery

Perfusion parameters

Cardioplegia

Aortic cross-clamp time

Duration of $\mathrm{CPB}$
Description

As discrete variables (i.e., < 57, 57-64, 65-70, and > 70 yrs.)

BP > 140/90 mmHg, a history of high BP, or the need for antihypertensive medications

A history of carotid disease (left and/or right) and/or prior carotid endarterectomy (left and/or right)

A history of diabetes, regardless of duration of disease, or need of insulin or oral hypoglycemic agents

$\mathrm{BMI}>25$

As documented in cardiology consultation

The presence of atrial or ventricular ectopy (i.e., ventricular or atrial fibrillation, AV block, or ventricular tachycardia)

Permanent or transient central neurological deficit; mental disturbance marked by illusions, confusion, and cerebral excitement; unresponsive coma $>24 \mathrm{~h}$

Defined as a significant renal complication with a serum creatinine level of $>150 \mu \mathrm{mol} / \mathrm{L}$

Divided into two groups: LVEF $<60 \%$ and VEF $>60 \%$

defined as prior stroke or TIA

A history of prior CABG or prior valve surgery

$\mathrm{mL} / 10 \mathrm{~kg} / \mathrm{min}$

Discrete variables (8-36, 37-48, 49-63, and 64-180 $\mathrm{min}$ )

Discrete variables (19-59; 60-75; 76-99; and 100-293 min)

*TIA = transient ischemic attack; LVEF = left ventricular ejection fraction; $\mathrm{BMI}=$ body mass index

\section{Data Analysis}

From the initial 1,408 cases, 13 patients were excluded from further analysis because of incomplete or missing data from the CPB. None of these excluded patients had severe postoperative neurologic complications. Subsequently, a set of data from 1,395 
cases was analyzed within a multidimensional space of 32 variables in order to identify data-dependent groups of perfusion patterns. One-way analysis of variance was used to compare the values of perfusion variables between patients who developed postoperative neurologic complications and those in whom such complications did not occur (Fig 1). A cluster analysis was used to look for "subpopulations" of patients, with respect to a selection of perfusion variables that were clinically relevant for postoperative neurologic complications. The following two procedures for cluster analysis were used: a hierarchical cluster analysis; followed by a K-means cluster analysis. This was done to fully profit from the strength of both procedures. The Kmeans cluster analysis is the ideal analysis for large patient groups, however, the algorithm requires one to specify the number of clusters. We wanted these tests to be as objective as possible. Therefore, we first performed a hierarchical cluster analysis in which the decision making on the number of clusters to be used is automated. The drawback of the hierarchical cluster analysis is the fact that it is not specifically designed for large patient groups. Therefore, we randomly selected (SPSS software; SPSS Inc. Chicago, IL) a group of 387 case patients ( $28 \%$ of the total population) for the hierarchical cluster analysis. Thus, the steps for the total clustering process were as follows.

The first step in the cluster analysis was the selection of variables to identify a likely set of variables to "carve" the patient population into subgroups (Fig 1). A preliminary analysis revealed that patients with and without complications in the early postoperative period had undergone perfusions that differed from each other on more than a dozen parameters. For the cluster procedure, we selected the most representative parameters from groups of closely correlated parameters (see "Results" section). As an exception to this rule, we included the properties of the MAP in the cluster procedure. This exception was based on the hypothesis that the MAP during $\mathrm{CPB}$ is of high clinical significance. Thus, five parameters (i.e., mean MAP, dispersion of $\mathrm{MAP}$, dispersion of SVR, dispersion of $\mathrm{AP}_{\text {pulse, }}$ and maximum $\mathrm{SvO}_{2}$ ) were selected for the cluster analysis. From these parameters, standardized values (i.e., Z-score variables) also were generated. This Z-score transformation was done to prevent the variables with greater variability to dominate the clustering.

The second step was a hierarchical cluster analysis on a random subset of cases (387 cases, as described above), which was performed with the Z-score variables generated before (Fig 1). During the clustering process, clusters were formed by grouping patients into bigger and bigger clusters until all patients were members of a single cluster. The results of the hierarchical cluster analysis were summarized in a socalled agglomeration schedule, which was presented as a table. This agglomeration schedule showed us the step-by-step clustering process and identified the clusters being combined at each stage. The results of this agglomeration schedule in a later 
phase helped us to decide how many clusters should be included in our present study. The cluster method chosen was the between-groups linkage, and the dissimilarity measure we chose was the "squared Euclidean distance." The latter allowed us to specify the distance or similarity measure to be used in clustering.

In the third step, one of the variables in the agglomeration schedule, the coefficients, were used to select a four-cluster solution for further analysis. Then, a K-means cluster analysis based on the Z-scores of the five selected parameters was used to cluster all cases [9]. 
Selection parameters for cluster procedure $(n=1395)$

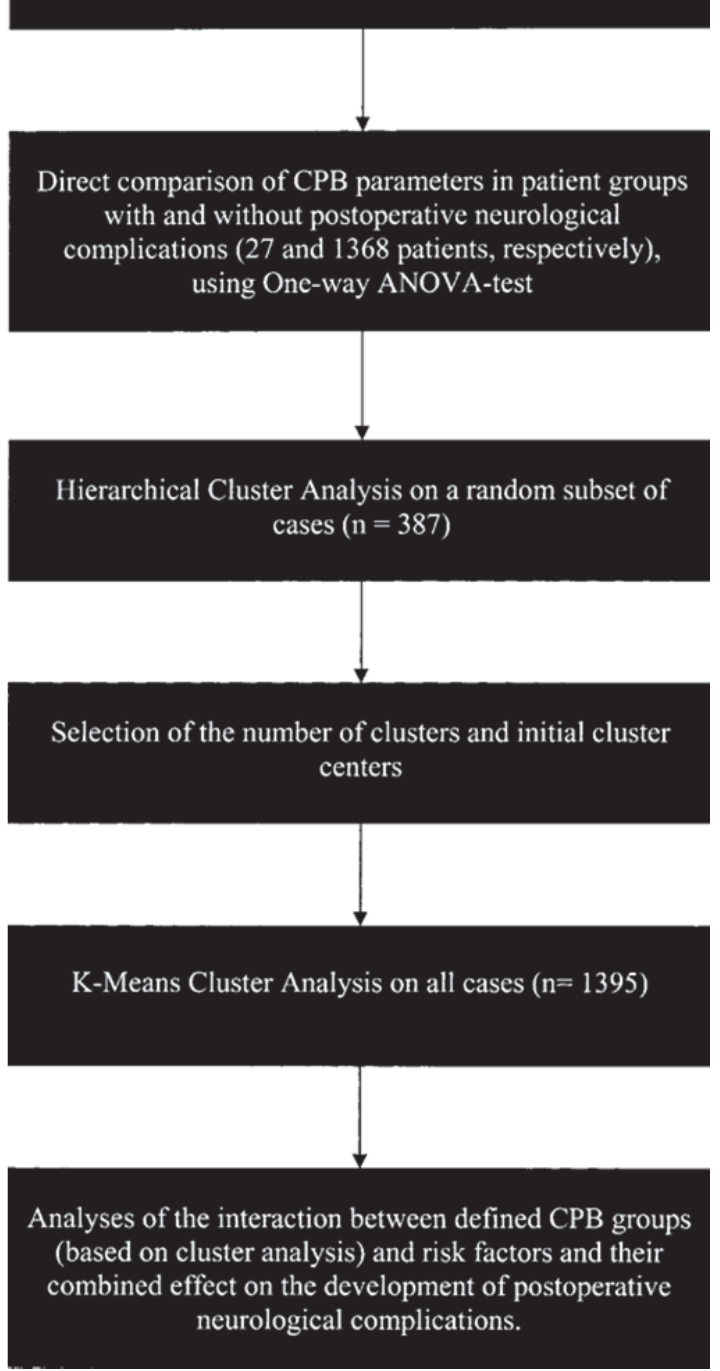

Figure 1.The flow chart of statistical analyses.

In order to study the interactions of patient age, duration of CPB, and development of neurologic complications, these continuous numeric data were converted to four discrete categories (Table 1) using the data transpose option of the software package (i.e., SPSS; SPSS Inc.). Analyses of the qualitative variables throughout the study were made using the $\chi^{2}$ test or extensions of the two-tailed Fisher exact test. One-way analysis of variance was used to compare the mean values of the quantitative variables 
in clusters. The multiple comparison Tukey honestly significant difference test or the Tamhane T2 test was used to find which means were different in the clusters. Data analyses were per- formed using a statistical software package (SPSS, version 9.01; SPSS/PC+; Chicago, IL).

\section{Results}

Among the 1,395 patients enrolled in our final analysis, 27 (1.9\%) had severe neurologic complications in the postoperative period. Demographic and clinical characteristics of all patients are shown in Table 2. A direct comparison of both patient groups points out that patients with postoperative neurologic complications were older, had previously experienced a cerebral stroke more often, had undergone more distal anastomoses, and had longer CPB and cross-clamp times. Postoperatively, the development of neurologic complications was associated with a number of other postoperative complications included in our study. Postoperatively, the majority of patients with a neurologic complication had this in combination with at least one other postoperative complication included in the analyses (22 of 27 patients; $81.5 \%$ ). The most common complication to coincide with a neurologic complication was cardiac arrhythmia (21 of 27 patients; $77.8 \%$ ).

CPB parameters in patients with or without post-operative neurologic complications are presented in Table 3. For the majority of parameters included in the present study, dispersion was significantly higher in patients with postoperative neurologic complications.

The separation of patients into four clusters is shown in Figure 2. Final cluster centers and related parameters are shown in Table 4. Clusters differed by all studied parameters, except for the maximum value of the arterial blood temperature. The first cluster united patients with a relatively "warm," stable full bypass period, as shown by the low dispersion values for all parameters. On the contrary, the fourth cluster united CPB procedures with high alterations, especially of the hemodynamic parameters. Table 4 shows that CPB procedures in the fourth cluster had the highest dispersion of MAP (mean \pm SD) MAP dispersion, $13.7 \pm 3.2 \mathrm{mmHg}$ ). In the fourth cluster, the MAP during CPB varied from $38 \pm 8$ to $97 \pm 12 \mathrm{~mm} \mathrm{Hg}$. In other words, the MAP during this type of CPB procedure varied by almost $60 \mathrm{mmHg}$. The same tendency was found for the BFI. The mean dispersion of blood flow during CPB in cluster 4 was $0.2 \pm 0.1$ $\mathrm{L} / \mathrm{min} / \mathrm{m} 2$ ( $p<0.001$ compared to any other cluster). The mean value of the BFI in CPB procedures from the cluster 4 was significantly lower than those in CPB procedures from cluster $1(p<0.001)$, but they did not differ from those in CPB procedures included in the clusters 2 and 3 . The lower BFI in these clusters could be related to a 
lower rectal temperature during CPB. A relatively high MAP in combination with low values of blood flow arbitrated that clusters 3 and 4 had the highest mean values of SVR during full bypass $\left(1,440 \pm 192\right.$ and 1,455 \pm 266 dyne $\cdot \mathrm{s} \cdot \mathrm{cm}^{-5}$, respectively). The fourth cluster had the highest values of SVR with an average maximum value up to 3,093 $\pm 1,860$ dyne $\cdot s \cdot \mathrm{cm}^{-5}$ ( $p<0.001$ compared to any other cluster). The clusters were also different in terms of demographic, clinical, and intraoperative characteristics, as shown in Table 5.

Table 2-Demographic, clinical, and operative characteristics of patient groups*

\begin{tabular}{|c|c|c|c|}
\hline \multirow[t]{2}{*}{ Variable } & \multicolumn{2}{|c|}{ Postoperative Neurologic Complications } & \multirow[t]{2}{*}{$\mathrm{p}$ Value } \\
\hline & Yes $(n=27)$ & No $(n=1,368)$ & \\
\hline Age, yr & $69 \pm 8$ & $63 \pm 9$ & $<0.01$ \\
\hline BSA, m2 & $1.85 \pm .2$ & $1.92 \pm .2$ & 0.04 \\
\hline Obesity (BMI > 25) & 66.7 & 69.5 & 0.83 \\
\hline Female sex & 40.7 & 25.5 & 0.08 \\
\hline Hypertension & 44.4 & 29.8 & 0.14 \\
\hline Previous cerebral incident & 29.6 & 6.4 & $<0.001$ \\
\hline Carotid disease & 11.1 & 3 & 0.05 \\
\hline Diabetes mellitus & 11.8 & 7.4 & 0.57 \\
\hline Prior cardiac surgery & 7.4 & 7.2 & $>0.99$ \\
\hline Preoperative LVEF $<60$ & 25.9 & 17.4 & 0.3 \\
\hline IABP before operation & 11.1 & 5.3 & 0.17 \\
\hline CPB duration, $\min$ & $103 \pm 43$ & $82 \pm 3$ & 0.01 \\
\hline ACC duration, $\min$ & $64 \pm 6$ & $52 \pm 22$ & 0.03 \\
\hline Cardioplegia, $\mathrm{mL} / 10 \mathrm{~kg} / \mathrm{min}$ & $2.9 \pm .3$ & $2.6 \pm .0$ & 0.79 \\
\hline Proximal anastomoses & $1.3 \pm .5$ & $1.1 \pm .4$ & $<0.01$ \\
\hline Distal anastomoses & $4.2 \pm .8$ & $3.7 \pm 1.1$ & 0.01 \\
\hline IABP after operation & 11.1 & 4.3 & 0.12 \\
\hline Postoperative cardiac arrhythmias & 77.8 & 23.1 & $<0.001$ \\
\hline Postoperative myocardial infarction & 14.8 & 3.6 & 0.02 \\
\hline Postoperative renal failure & 25.9 & 5.3 & $<0.01$ \\
\hline
\end{tabular}

*Values given as mean \pm SD or $\%$, unless otherwise indicated. ACC = aortic cross-clamping; BSA = body surface area; IABP = intraaortic balloon pump. See Table 1 for other abbreviations not used in the text. 
Table 3-Perfusion parameters in both patient groups*

\begin{tabular}{|c|c|c|c|c|}
\hline \multirow[t]{2}{*}{ Variable } & \multirow{2}{*}{$\begin{array}{l}\text { Parameter } \\
\text { Properties }\end{array}$} & \multicolumn{2}{|c|}{ Postoperative Neurologic Complications } & \multirow[t]{2}{*}{$\mathrm{p}$ Value } \\
\hline & & Yes $(n=27)$ & No $(n=1,368)$ & \\
\hline \multirow[t]{4}{*}{$\mathrm{BFI}, \mathrm{L} / \mathrm{min} / \mathrm{m}^{2}$} & Mean & $2.4 \pm 0.2$ & $2.3 \pm 0.2$ & 0.13 \\
\hline & Dispersion & $0.15 \pm 0.08$ & $0.12 \pm 0.09$ & 0.14 \\
\hline & Maximum & $2.7 \pm 0.2$ & $2.6 \pm 0.2$ & 0.02 \\
\hline & Minimum & $1.3 \pm 0.7$ & $1.5 \pm 0.7$ & 0.13 \\
\hline \multirow[t]{4}{*}{ MAP, mmHg } & Mean & $66.6 \pm 13.4$ & $63.2 \pm 10.6$ & 0.11 \\
\hline & Dispersion & $9.9 \pm 3.9$ & $8.5 \pm 3.6$ & 0.04 \\
\hline & Maximum & $87.8 \pm 17.6$ & $82.8 \pm 14.7$ & 0.08 \\
\hline & Minimum & $41.3 \pm 11.6$ & $42.9 \pm 10.3$ & 0.41 \\
\hline \multirow[t]{4}{*}{ APpulse, $\mathrm{mmHg}$} & Mean & $24.9 \pm 6.8$ & $22.2 \pm 7.7$ & 0.07 \\
\hline & Dispersion & $5.3 \pm 2.2$ & $3.9 \pm 2.2$ & $<0.001$ \\
\hline & Maximum & $35.4 \pm 8.8$ & $30.7 \pm 11.3$ & 0.03 \\
\hline & Minimum & $8.74 \pm 5.9$ & $8.6 \pm 5.8$ & 0.87 \\
\hline \multirow[t]{4}{*}{ SVR, dyne $\cdot s \cdot \mathrm{cm}^{-5}$} & Mean & $1343 \pm 246$ & $1258 \pm 254$ & 0.08 \\
\hline & Dispersion & $251 \pm 128$ & $194 \pm 107$ & $<0.01$ \\
\hline & Maximum & $2754 \pm 1720$ & $2152 \pm 1209$ & 0.01 \\
\hline & Minimum & $780 \pm 168$ & $815 \pm 216$ & 0.4 \\
\hline \multicolumn{5}{|l|}{ Temperature, ${ }^{\circ} \mathrm{C}$} \\
\hline \multirow[t]{4}{*}{ Arterial } & Mean & $31.0 \pm 2.2$ & $31.8 \pm 2.3$ & 0.08 \\
\hline & Dispersion & $2.5 \pm 1.2$ & $2.1 \pm 1.1$ & 0.07 \\
\hline & Maximum & $36.2 \pm 1.9$ & $36.3 \pm 1.6$ & 0.76 \\
\hline & Minimum & $26.6 \pm 4.1$ & $27.7 \pm 3.8$ & 0.16 \\
\hline \multirow[t]{4}{*}{ Rectal } & Mean & $32.0 \pm 2.0$ & $32.8 \pm 1.9$ & 0.04 \\
\hline & Dispersion & $1.1 \pm 0.5$ & $0.8 \pm 0.5$ & 0.02 \\
\hline & Maximum & $34.7 \pm 2.5$ & $34.9 \pm 1.4$ & 0.45 \\
\hline & Minimum & $30.7 \pm 2.5$ & $31.7 \pm 2.5$ & $<0.01$ \\
\hline \multirow[t]{4}{*}{$\mathrm{PaO}_{2}, \mathrm{kPa}$} & Mean & $17 \pm 5$ & $16 \pm 5$ & 0.32 \\
\hline & Dispersion & $2.8 \pm 1.5$ & $2.7 \pm 1.6$ & 0.72 \\
\hline & Maximum & $28 \pm 9$ & $26 \pm 10$ & 0.33 \\
\hline & Minimum & $11 \pm 1$ & $10 \pm 1$ & 0.29 \\
\hline \multirow[t]{4}{*}{$\mathrm{SvO}_{2}, \%$} & Mean & $79.6 \pm 5.9$ & $76.1 \pm .4$ & $<0.01$ \\
\hline & Dispersion & $4.2 \pm 1.8$ & $3.5 \pm 1.6$ & 0.02 \\
\hline & Maximum & $86.6 \pm 5.0$ & $82.5 \pm 6.0$ & $<0.001$ \\
\hline & Minimum & $66.3 \pm 9.3$ & $65.3 \pm 7.8$ & 0.51 \\
\hline
\end{tabular}

*Values given as mean \pm SD, unless otherwise indicated. 


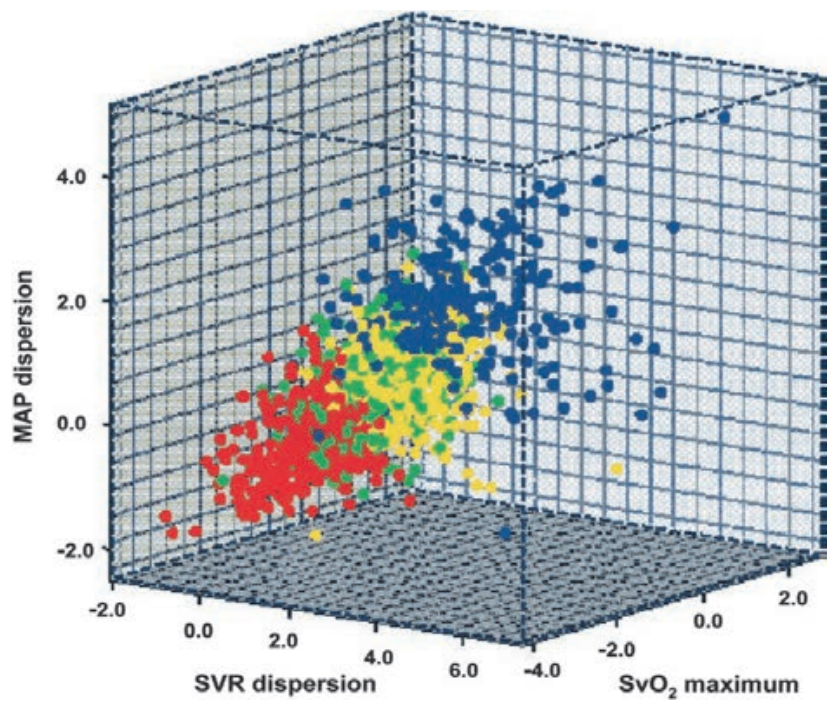

Figure 2. The graphical presentation of 4 clusters in three dimensional space. Red dots mark cluster 1 , green dots mark cluster 2, yellow dots mark cluster 3 , and blue dots mark cluster 4 .

Table 5 shows that the fourth cluster contains the oldest patients, the highest percentage of female patients, and patients with cerebrovascular disease in their medical histories. The cluster means of CPB duration, cross-clamp time, and number of distal anastomoses were statistically different among clusters $(p<0.001)$. Post hoc testing showed that the mean CPB duration in the second and third clusters and in the third and fourth clusters were equal (Table 5). Also, although a significant difference was found for the aortic cross-clamping times between clusters, the aortic cross clamp times in clusters 3 and 4 were identical. The mean number of distal anastomoses was significantly lower in the first cluster compared to all other clusters $(p<0.05)$ and was identical for clusters 2 to 4 . The frequency of postoperative neurologic complications was the lowest in the first cluster $(0.3 \%)$ and increased up to $3.9 \%$ in the fourth cluster $(p<0.01$ ) (Table 5). From the 389 patients in the first cluster, only 1 patient $(0.3 \%)$ had a postoperative neurologic disorder, which was experienced in combination with cardiac arrhythmias and renal failure. In the first cluster, 12 patients (3.1\%) had a cerebral incident in their medical history. Remarkably, none of them developed neurologic complications in the postoperative period. The frequency of postoperative neurologic complications in the second cluster was $2.3 \%$ (10 patients), and the occurrence of this was associated with the occurrence of postoperative cardiac arrhythmias $(p<0.001)$. We did not find any association between the development of neurologic complications and any other demographic or clinical characteristic in this cluster. In the second cluster, $35 \%$ of all patients with cerebrovascular disease in their 
medical history were included. None of these patients experienced a postoperative neurologic complication. Also, none of the 16 patients with carotid disease who were included in this cluster experienced a postoperative neurologic complication. In the third cluster, the frequency of postoperative neurologic complications was $2.0 \%$. Cluster 3 contained 22 patients with a medical history of cerebral disease. Two of these patients (9.1\%) developed neurologic complications postoperatively, but this association was not significant. However, the occurrence of postoperative neurologic complications in patients of the third cluster was associated with carotid disease and postoperative renal failure ( $p<0.01$ and $p<0.05$, respectively). In the fourth cluster, the development of postoperative neurologic complications was associated with the occurrence of a perioperative myocardial infarction and postoperative cardiac arrhythmias ( $p<0.01$ and $p<0.001$, respectively). From nine patients in the fourth cluster who experienced postoperative neurologic complications, eight patients (88.9\%) had a combination of several postoperative complications. The occurrence of postoperative neurologic complications in this group of patients was particularly associated with hypertension and the presence of cerebrovascular disease in their medical histories ( $p<0.05$ and $p<0.001$, respectively). Despite the differences between the clusters with respect to gender, age, and CPB duration (Table 5), we did not find a statistically significant association between these factors and postoperative neurologic complications in any of the clusters.

Table 4 -Perfusion Parameters in Clusters*

\begin{tabular}{|c|c|c|c|c|c|}
\hline \multirow[t]{2}{*}{ Parameter } & \multirow{2}{*}{$\begin{array}{l}\text { Parameter } \\
\text { Properties }\end{array}$} & \multicolumn{4}{|l|}{ Cluster No } \\
\hline & & $1(n=389)$ & $2(n=431)$ & $3(n=348)$ & $4(n=229)$ \\
\hline \multirow[t]{4}{*}{$\mathrm{BFI}, \mathrm{L} / \mathrm{min} / \mathrm{m}$} & Mean & $2.4 \pm 0.2$ & $2.3 \pm 0.2$ & $2.3 \pm 0.2$ & $2.3 \pm 0.2$ \\
\hline & Dispersion & $0.10 \pm 0.07$ & $0.13 \pm 0.09$ & $0.10 \pm 0.07$ & $0.19 \pm 0.12$ \\
\hline & Maximum & $2.6 \pm 0.2$ & $2.6 \pm 0.2$ & $2.5 \pm 0.2$ & $2.6 \pm 0.2$ \\
\hline & Minimum & $1.6 \pm 0.6$ & $1.4 \pm 0.7$ & $1.5 \pm 0.6$ & $1.3 \pm 0.7$ \\
\hline \multirow[t]{4}{*}{$\mathrm{MAP}, \mathrm{mmHg}$} & Mean & $56.3 \pm 7.4$ & $57.4 \pm 6.5$ & $75.0 \pm 6.6$ & $68.5 \pm 8.7$ \\
\hline & Dispersion & $5.5 \pm 2.2$ & $8.6 \pm 2.3$ & $8.5 \pm 2.5$ & $13.7 \pm 3.2$ \\
\hline & Maximum & $71.1 \pm 10.0$ & $77.1 \pm 9.8$ & $93.8 \pm 9.5$ & $97.2 \pm 12.8$ \\
\hline & Minimum & $43.3 \pm 9.2$ & $38.1 \pm 7.6$ & $51.3 \pm 10.2$ & $38.3 \pm 8.5$ \\
\hline \multirow[t]{4}{*}{ APpulse, $\mathrm{mmHg}$} & Mean & $18.7 \pm 6.6$ & $22.5 \pm 7.1$ & $23.1 \pm 7.6$ & $26.5 \pm 8.1$ \\
\hline & Dispersion & $2.5 \pm 1.1$ & $4.1 \pm 1.6$ & $3.4 \pm 1.4$ & $6.9 \pm 2.6$ \\
\hline & Maximum & $24.3 \pm 7.8$ & $31.4 \pm 9.2$ & $30.5 \pm 9.2$ & $41.4 \pm 14.1$ \\
\hline & Minimum & $8.6 \pm 5.8$ & $8.6 \pm 5.6$ & $9.1 \pm 6.5$ & $7.6 \pm 5.1$ \\
\hline \multirow{4}{*}{$\begin{array}{l}\text { SVR, } \\
\text { dyne } \cdot s \cdot c m-5\end{array}$} & Mean & $1,074 \pm 168$ & $1,178 \pm 179$ & $1,440 \pm 192$ & $1,455 \pm 266$ \\
\hline & Dispersion & $115 \pm 49$ & $195 \pm 66$ & $177 \pm 54$ & $358 \pm 126$ \\
\hline & Maximum & $1,672 \pm 647$ & $2,077 \pm 1,174$ & $2,209 \pm 845$ & $3,093 \pm 1,860$ \\
\hline & Minimum & $810 \pm 184$ & $738 \pm 191$ & $955 \pm 219$ & $755 \pm 197$ \\
\hline
\end{tabular}




\begin{tabular}{|c|c|c|c|c|c|}
\hline \multirow[t]{2}{*}{ Parameter } & \multirow{2}{*}{$\begin{array}{l}\text { Parameter } \\
\text { Properties }\end{array}$} & \multicolumn{4}{|l|}{ Cluster No } \\
\hline & & $1(n=389)$ & $2(n=431)$ & $3(n=348)$ & $4(n=229)$ \\
\hline \multicolumn{6}{|c|}{ Temperature, ${ }^{\circ} \mathrm{C}$} \\
\hline \multirow[t]{4}{*}{ Arterial } & Mean & $33.3 \pm 2.5$ & $31.1 \pm 2.0$ & $31.4 \pm 1.9$ & $31.2 \pm 2.2$ \\
\hline & Dispersion & $1.5 \pm 0.1$ & $2.4 \pm 1.0$ & $2.2 \pm 0.9$ & $2.4 \pm 1.1$ \\
\hline & Maximum & $36.3 \pm 1.6$ & $36.2 \pm 1.6$ & $36.4 \pm 1.5$ & $36.3 \pm 1.7$ \\
\hline & Minimum & $30.1 \pm 4.1$ & $26.3 \pm 2.9$ & $27.4 \pm 3.1$ & $26.3 \pm 3.9$ \\
\hline \multirow[t]{4}{*}{ Rectal } & Mean & $34.1 \pm 1.9$ & $32.2 \pm 1.6$ & $32.4 \pm 1.6$ & $32.1 \pm 1.9$ \\
\hline & Dispersion & $0.6 \pm 0.4$ & $0.9 \pm 0.4$ & $0.9 \pm 0.4$ & $1.0 \pm 0.6$ \\
\hline & Maximum & $35.4 \pm 1.4$ & $34.6 \pm 1.3$ & $34.7 \pm 1.2$ & $34.7 \pm 1.6$ \\
\hline & Minimum & $33.3 \pm 2.4$ & $31.0 \pm 2.0$ & $31.2 \pm 2.0$ & $30.7 \pm 2.6$ \\
\hline \multirow[t]{4}{*}{$\mathrm{PaO}_{2}, \mathrm{kPa}$} & Mean & $119 \pm 36$ & $124 \pm 43$ & $117 \pm 20$ & $123 \pm 36$ \\
\hline & Dispersion & $19 \pm 11$ & $21 \pm 12$ & $19 \pm 7$ & $24 \pm 16$ \\
\hline & Maximum & $190 \pm 84$ & $197 \pm 73$ & $195 \pm 60$ & $210 \pm 82$ \\
\hline & Minimum & $77 \pm 35$ & $77 \pm 34$ & $72 \pm 19$ & $74 \pm 26$ \\
\hline \multirow[t]{4}{*}{ Svo $2, \%$} & Mean & $71.3 \pm 5.8$ & $78.9 \pm 5.1$ & $77.2 \pm 5.5$ & $77.9 \pm 6.2$ \\
\hline & Dispersion & $2.9 \pm 1.2$ & $3.8 \pm 1.8$ & $3.5 \pm 1.3$ & $4.1 \pm 1.9$ \\
\hline & Maximum & $77.4 \pm 5.2$ & $85.5 \pm 4.3$ & $83.1 \pm 4.9$ & $85.2 \pm 5.7$ \\
\hline & Minimum & $62.6 \pm 7.0$ & $67.8 \pm 7.5$ & $65.4 \pm 7.5$ & $65.2 \pm 8.5$ \\
\hline
\end{tabular}

*Values given as mean \pm SD. The variables included in the cluster procedure (final cluster centers) are presented in bold.

Table 5 Demographic, Clinical, and Operative Characteristics of the Study Patients in Clusters*

\begin{tabular}{|c|c|c|c|c|}
\hline \multirow[t]{2}{*}{ Variable } & \multicolumn{4}{|l|}{ Cluster No } \\
\hline & $1(n=389)$ & $2(n=431)$ & $3(n=348)$ & $4(n=229)$ \\
\hline Age, yr & $62 \pm 10$ & $65 \pm 9$ & $61 \pm 10$ & $66 \pm 9$ \\
\hline BSA, $\mathrm{m}^{2}$ & $1.93 \pm 0.2$ & $1.89 \pm 0.2$ & $1.99 \pm 0.2$ & $1.85 \pm 0.2$ \\
\hline Obesity (BMI > 25) & 71.3 & 65.7 & 76.4 & 62.7 \\
\hline Female sex & 27.1 & 29.9 & 11.5 & 37.6 \\
\hline Previous cerebral incident & 3.1 & 7.7 & 6.6 & 11.8 \\
\hline CPB duration, $\min$ & $65 \pm 23$ & $85 \pm 33$ & $90 \pm 32$ & $96 \pm 38$ \\
\hline ACC duration, $\min$ & $41 \pm 16$ & $54 \pm 22$ & $59 \pm 23$ & $59 \pm 23$ \\
\hline Cardioplegia, $\mathrm{mL} / 10 \mathrm{~kg} / \mathrm{min}$ & $3.0 \pm 1.1$ & $2.6 \pm 0.9$ & $2.3 \pm 0.8$ & $2.6 \pm 0.9$ \\
\hline Distal anastomoses & $3.3 \pm 1.1$ & $3.8 \pm 1.1$ & $3.9 \pm 1.2$ & $3.8 \pm 1.1$ \\
\hline Postoperative neurologic complications & 0.3 & 2.3 & 2 & 3.9 \\
\hline Postoperative renal failure & 3.6 & 5.8 & 5.2 & 9.6 \\
\hline
\end{tabular}

*Values given as mean \pm SD or $\%$. Only factors that significantly differed between clusters are presented. See Tables 1 and 2 for abbreviations not used in the text. 


\section{Discussion}

Neurologic complications after coronary artery bypass surgery substantially increase mortality, put a strain on health-care resources, and reduce the clinical effectiveness of the procedure $[8,10,11]$. Customarily, these complications have been attributed mainly to the effects of CPB [8]. Nowadays, complications associated with the use of CPB have gained even more attention due to the rediscovering and growing interest in "offpump" CABG. The reported incidence of neurologic complications after CABG with CPB varies from 0.8 to $3.2 \%$ in retrospective studies [1,12-14] and from 1.5 to $5.2 \%$ in prospective studies $[2,15,16]$. The frequency of severe postoperative neurologic disorders in the present study $(1.9 \%)$ is in line with these previous findings.

Previous studies identified individual factors related to postoperative neurologic complications. Among them were age, gender, arterial hypertension, diabetes mellitus, carotid stenosis, previous cerebrovascular disease, preoperative and postoperative arrhythmias, requirement of using an intra- aortic balloon pump, duration of CPB and aortic cross clamping, and the number of anastomoses performed [8,14,17-22]. However, in most of these studies these factors were examined individually, which led to conflicting reports in the literature [15]. For example, some studies $[8,18]$ have demonstrated that advanced age and previous cerebrovascular disease are powerful predictors of postoperative stroke, whereas others $[3,4,23]$ have not found such an association. The results from our direct comparison of groups of patients with and without postoperative neurologic complications are consistent with those of the studies in which age and a history of cerebral stroke increased the probability of postoperative neurologic complications. Also, in the present study, the group of patients with postoperative neurologic complications had more distal anastomoses performed, and had longer CPB and cross-clamp times. However, other common risk factors were not significantly associated with the incidence of postoperative neurologic complications in the present. Gender, hypertension, carotid disease, and diabetes mellitus all were not directly associated with these complications. Our findings, however, support re- ports in which postoperative neurologic events were linked to the development of cardiac arrhythmias [24], myocardial infarction [25], or renal failure $[25,26]$.

CPB is still an important, intrinsic part of coronary artery bypass surgery. Yet, data on the impact of apparently normal CPB procedures on the development neurologic complications are rare and usually are from studies performed in small, selected groups of patients. Furthermore, these studies were mainly focused on a single characteristic of CPB (e.g., temperature [27], pulsatility of flow [28], or acid-base management [29]). The multifactorial nature of neurologic complications after CPB makes the results of such investigations controversial. Determining "true" predictors 
of postoperative neurologic complications is furthermore hampered by the small numnumber of outcome events in data collection $[16,30]$ and by the low incidence of major neurologic complications [1-4]. This and the multifactorial etiology of postoperative neurologic complications [31] do not favor the use of conventional statistical methods. The cluster analysis used in the present study was developed in the 1960s and has been used in studies of pattern recognition, artificial intelligence and neural network development, social sciences, and epidemiology [9]. Until now, however, this method rarely has been applied in clinical studies [31-34]. In the present study, the separation of large groups of similar CPB characteristics by means of cluster analysis enabled us to overcome the above-mentioned limitations. Despite the small number of patients with postoperative neurologic complications, the use of cluster analysis enabled us to study the interaction between risk factors for postoperative neurologic complications and CPB. Most of the known risk factors appeared not to be the ultimate, independent predictors that predispose CABG patients to postoperative neurologic complications, yet their impact showed to be altered by the performance of the CPB procedure.

In the present study, patients in the fourth cluster had the most frequent fluctuations of hemodynamic parameters, which resulted in an almost 10 -fold increase of the risk for major postoperative neurologic complications compared to patients in the first cluster. Furthermore, in patients with cerebrovascular disease in their medical history who were included in the fourth cluster, the incidence of post- operative neurologic complications reached $22.2 \%$. On the contrary, in the second cluster, in which $35 \%$ of all patients with cerebrovascular disease in their medical history were merged, none of the patients experienced a postoperative neurologic complication. Also, only in the fourth cluster was the development of major postoperative neurologic complications associated with a history of hypertension and/or cerebrovascular disease. Surprisingly, the occurrence of postoperative neurologic complications was associated with carotid disease only in patients in cluster 3.

The results of our direct comparison of groups with and without postoperative neurologic complications are consistent with those of studies in which age and duration of CPB and clamp-time are significant predictors of postoperative neurologic complications [15]. However, the impact of these factors dis appeared when we analyzed them using cluster analysis. However, what we found in the cluster analysis, as well as in a direct comparison of groups with and without neurologic complications, was a strong association of postoperative neurologic complications with other postoperative complications. The development of severe postoperative neurologic events in all but the first clusters was statistically related to at least one coexistent complication. However, the interrelationship of these events makes the identification 
of the relative contribution of each single variable difficult. Therefore, further studies are necessary to elucidate the relationship of these complications.

In conclusion, this study shows that apparently normal CPB procedures affect the impact of common clinical risk factors on postoperative neurologic complications. Particularly, patients who underwent CPB procedures with large fluctuations in hemodynamic parameters showed an increased risk for the development of postoperative neurologic complications. 


\section{References}

1. Carrascal Y, Guerrero AL, Maroto LC, et al. Neurological complications after cardiopulmonary bypass: an update. Eur Neurol 1999; 41:128-134.

2. Bull DA, Neumayer LA, Hunter GC, et al. Risk factors for stroke in patients undergoing coronary artery bypass grafting. Cardiovasc Surg 1993; 1:182-185.

3. Cernaianu AC, Vassilidze TV, Flum DR, et al. Predictors of stroke after cardiac surgery. J Card Surg 1995; 10:334-339.

4. Craver JM, Puskas JD, Weintraub WW, et al. 601 octogenarians undergoing cardiac surgery: outcome and comparison with younger age groups. Ann Thorac Surg 1999; 67:1104-1110.

5. Herlitz J, Brandrup-Wognsen G, Haglid M, et al. Mortality and morbidity during a period of 2 years after coronary artery bypass surgery in patients with and without a history of hypertension. $J$ Hypertens 1996; 14:309-314.

6. Gardner TJ, Horneffer PJ, Manolio TA, et al. Major stroke after coronary artery bypass surgery: changing magnitude of the problem. J Vasc Surg 1986; 3:684-687.

7. Alexander KP, Anstrom KJ, Muhlbaier LH, et al. Outcomes of cardiac surgery in patients $>$ or $=80$ years: results from the National Cardiovascular Network. J Am Coll Cardiol 2000; 35:731-738.

8. Murkin JM. Etiology and incidence of brain dysfunction after cardiac surgery. J Cardiothorac Vasc Anesth 1999; 13:12-17.

9. Kaufman L, Rousseeuw PJ. Finding groups in data: an introduction to cluster analysis. New York, NY: John Wiley \& Sons, 1990.

10. Taylor KM. Central nervous system effects of cardiopulmonary bypass. Ann Thorac Surg 1998; 66:S20 S24.

11. Utley JR. Techniques for avoiding neurologic injury during adult cardiac surgery. J Cardiothorac Vasc Anesth 1996; 10:38-43.

12. Pompilio G, Lotto AA, Agrifoglio $M$, et al. Nonembolic predictors of stroke risk in coronary artery bypass patients. World J Surg 1999; 23:657-663.

13. Kolh PH, Torchiana DF, Buckley MJ. Atheroembolization in cardiac surgery: the need for preoperative diagnosis. J Cardiovasc Surg 1999; 40:77-81.

14. Ahlgren E, Aren C. Cerebral complications after coronary artery bypass and heart valve surgery: risk factors and onset of symptoms. J Cardiothorac Vasc Anesth 1998; 12:270-273.

15. McKhann GM, Goldsborough MA, Borowicz LM Jr, et al. Predictors of stroke risk in coronary artery bypass patients. Ann Thorac Surg 1997; 63:516-521.

16. Newman MF, Wolman R, Kanchuger M, et al. Multicenter preoperative stroke risk index for patients undergoing coronary artery bypass graft surgery: Multicenter Study of Perioperative Ischemia (McSPI) Research Group. Circulation 1996; 94:II74-II80.

17. Hogue CW Jr, Murphy SF, Schechtman KB, et al. Risk factors for early or delayed stroke after cardiac surgery. Circulation 1999; 100:642-647.

18. Redmond JM, Greene PS, Goldsborough MA, et al. Neurologic injury in cardiac surgical patients with a history of stroke. Ann Thorac Surg 1996; 61:42-47.

19. Dashe JF, Pessin MS, Murphy RE, et al. Carotid occlusive disease and stroke risk in coronary artery bypass graft surgery. Neurology 1997; 49:678-686.

20. Herlitz J, Brandrup-Wognsen G, Karlson BW, et al. Mortality, risk indicators, mode and place of death and symptoms of angina pectoris in the five years after coronary artery bypass grafting in patients with and without a history of hypertension. Blood Press 1999; 8:200-206.

21. Rolfson DB, McElhaney JE, Rockwood K, et al. Incidence and risk factors for delirium and other adverse outcomes in older adults after coronary artery bypass graft surgery. Can J Cardiol 1999; 15:771-776. 
22. Morricone L, Ranucci M, Denti S, et al. Diabetes and complications after cardiac surgery: comparison with a non- diabetic population. Acta Diabetol 1999; 36:77-84.

23. Beall AC Jr, Jones JW, Guinn GA, et al. Cardiopulmonary bypass in patients with previously completed stroke. Ann Thorac Surg 1993; 55:1383-1384.

24. Almassi GH, Schowalter T, Nicolosi AC, et al. Atrial fibrilla- tion after cardiac surgery: a major morbid event? Ann Surg 1997; 226:501-511.

25. Saimanen El. Perioperative stroke in coronary artery bypass surgery: analysis of risk factors. Scand Cardiovasc J 2000; 34:41-45.

26. Anderson RJ, O'Brien M, MaWhinney S, et al. Renal failure predisposes patients to adverse outcome after coronary artery bypass surgery: VA Cooperative Study \#5. Kidney Int 1999; 55:1057-1062.

27. Insler SR, O'Connor MS, Leventhal MJ, et al. Association between postoperative hypothermia and adverse outcome after coronary artery bypass surgery. Ann Thorac Surg 2000; 70:175-181.

28. Chow G, Roberts IG, Harris D, et al. Stockert roller pump generated pulsatile flow: cerebral metabolic changes in adult cardiopulmonary bypass. Perfusion 1997; 12:113-119.

29. Stephan H, Weyland A, Kazmaier S, et al. Acid-base management during hypothermic cardiopulmonary bypass does not affect cerebral metabolism but does affect blood flow and neurological outcome. Br J Anaesth 1992; 69:51-57.

30. Kleinbaum DG, Kupper LL, Muller KE, et al. Applied regression analysis and other multivariable methods. 3rd ed. Pacific Grove, CA: Brooks/Cole Publishing Company, 1998.

31. Walzer T, Herrmann M, Wallesch CW. Neuropsychological disorders after coronary bypass surgery. $J$ Neurol Neurosurg Psychiatry 1997; 62:644-648.

32. Knyshov HV, Palets BL, Nastenko le A, et al. The heart pumping function and the systemic regulation of blood circulation in groups of heart surgery patients. Fiziol Zh 1996; 42:3-18.

33. Marshall G, Henderson WG, Moritz TE, et al. Statistical methods and strategies for working with large data bases. Med Care 1995; 33:OS35-OS42.

34. Marshall G, Grover FL, Henderson WG, et al. Assessment of predictive models for binary outcomes: an empirical approach using operative death from cardiac surgery. Stat Med 1994; 13:1501-1511. 



\section{CHAPTER 3}

\section{The oxygen debt during routine cardiac surgery: illusion or reality?}

YM Ganushchak, JG Maessen and DS de Jong

Published in: Perfusion 2002; 17:167-173. 


\section{Abstract}

Background: Patients undergoing cardiac surgery with the use of cardiopulmonary bypass (CPB) are often thought to have tissue hypoxia and intraoperative oxygen debt accumulation despite the lack of sufficient data to support this assumption.

Methods and results: Oxygen uptake and related parameters, including the plasma lactate and pyruvate concentrations, were studied during the perioperative period in a group of 15 consecutive patients who underwent coronary artery bypass graft surgery. The actual oxygen uptake $\left(\mathrm{VO}_{2}\right)$ and delivery $\left(\mathrm{DO}_{2}\right)$ were compared with the individual expected (computed) oxygen transport values. The mean values of $\mathrm{DO}_{2}$ and $\mathrm{VO}_{2}$ were in the range of the expected values. Our results demonstrate a leading role for body temperature in perioperative changes of oxygen consumption rate $\left(r^{2}=0.65, p<0.001\right)$. Plasma lactate and pyruvate did not exceed the physiological range in any patient. However, with initiation of CPB, the lactate to pyruvate (LA/PVA) ratio increased (from $9.87+/-2.43$ at $\mathrm{T} 1$ to $12.08+/-1.51$ at $\mathrm{T} 2, \mathrm{p}<0.05)$. The mean value of the LA/PVA ratio was elevated during surgery. Later, upon lowering of the plasma lactate concentration in the postoperative period, the LA/PVA ratio decreased to normal values. Without any other evidence of hypoxia, this increase in the LA/PVA ratio could be explained by washout of lactate from previously hypo-perfused tissues and intraoperative decrease of lactate clearance.

Conclusion: Systemic oxygenation was not impaired during CPB or during $18 \mathrm{~h}$ after surgery in the studied group of patients. 


\section{Introduction}

Patients undergoing cardiac surgery with the use of cardiopulmonary bypass (CPB) are often thought to have tissue hypoxia and intraoperative oxygen debt accumulation [14]. The development of tissue hypoxia and oxygen debt has several attributes. A biphasic response with reduced oxygen consumption (VO2) and reduced cardiac output (CO) during surgery, followed by an increment of values of these parameters in the postoperative period $[5,6]$ is the fundamental syndrome of the oxygen debt theory. The association between oxygen delivery and consumption is another recognized symptom of oxygen debt state [2, 4, 7-11]. Recently, however, most of these reports have been criticized because of their methodology [12, 13].

This study was initiated in order to determine the existence and causes of the oxygen debt during cardiac surgery. To find out if, in fact, there is a general tissue hypoxia and intraoperative oxygen debt accumulation in cardiac surgical patients, oxygen uptake and related parameters were studied during the intra- and postoperative periods in a group of patients who underwent coronary artery bypass graft (CABG) surgery. Actual oxygen uptake and delivery were compared with the individual expected (computed) oxygen transport parameters in order to calculate the oxygen consumption deficit time curve. Additionally, we studied the dynamics of lactic acid and pyruvate concentration in the same period.

\section{Methods}

The study was performed in 15 consecutive patients ( 12 male and 3 female), aged 61.1 \pm 8.9 years (mean \pm SD). All selected patients underwent elective CABG surgery and preoperatively they were in New York Heart Association (NYHA) class III or IV. Patients with hepatic or renal insufficiency, diabetes mellitus or thyroid diseases, severe hypertension, or a history of neurological disorder were excluded from the study. Patients with heart failure or rethoracotomy after surgery were also excluded from further investigation. The local ethical review board approved the study. The study was observational and did not involve any intervention beyond normal management. For this reason, a written informed consent was not required.

The conduct of anaesthesia and CPB was done by standard hospital practice. The patients received general anaesthesia. Induction: midazolam $(0.06-0.08 \mathrm{mg} / \mathrm{kg})$, sufentanyl (1 - $1.5 \mathrm{mg} / \mathrm{kg})$; neuromuscular blockade: pavulon (0.1 mg/kg); maintenance: sufentanyl (0.5 - $1.25 \mathrm{mg} / \mathrm{kg} / \mathrm{h})$, or/and propofol infusion (3 - 6 $\mathrm{mg} / \mathrm{kg} / \mathrm{h})$. 
The bypass circuit consisted of a hollow-fibre oxygenator (Univox ${ }^{\mathrm{TM}}$, Bentley/Baxter, Irvine, CA, USA or Capiox SX Terumo, Tokyo, Japan), an arterial line filter (Pall Biomedical, Portsmouth, UK) and a roller pump (Stöckert Instruments, Munich, Germany). The circuit was primed with a mixture of Haemaccel $(3.5 \%, 1200 \pm 1300 \mathrm{ml})$, mannitol (20\%, $200 \mathrm{ml})$, human albumin $(20 \%, 100 \mathrm{ml})$, and NaHCO3 $(8.4 \%, 50 \mathrm{ml})$, potassium chloride $(20 \mathrm{mmol})$, and heparin $(50 \mathrm{mg} / 1000 \mathrm{ml}$ prime). CPB was carried out by means of pulsatile flow with a flow range of approximately $2.4 \mathrm{l} / \mathrm{min} / \mathrm{m}^{2}$. Moderate hypothermia $\left(28-32^{\circ} \mathrm{C}\right)$ was applied during perfusion. Modified St. Thomas solution was used to arrest the heart and to maintain an iso-electrical state of the heart. After release of the aortic clamp, a nitroglycerine infusion $(0.5 \mathrm{mg} / \mathrm{kg} / \mathrm{min})$ was started.

After surgery and return to the intensive care unit, standard patient management protocols were applied. Patients were weaned from mechanical ventilation as soon as haemodynamic and respiratory stability had been established and they were awake and orientated in space and time.

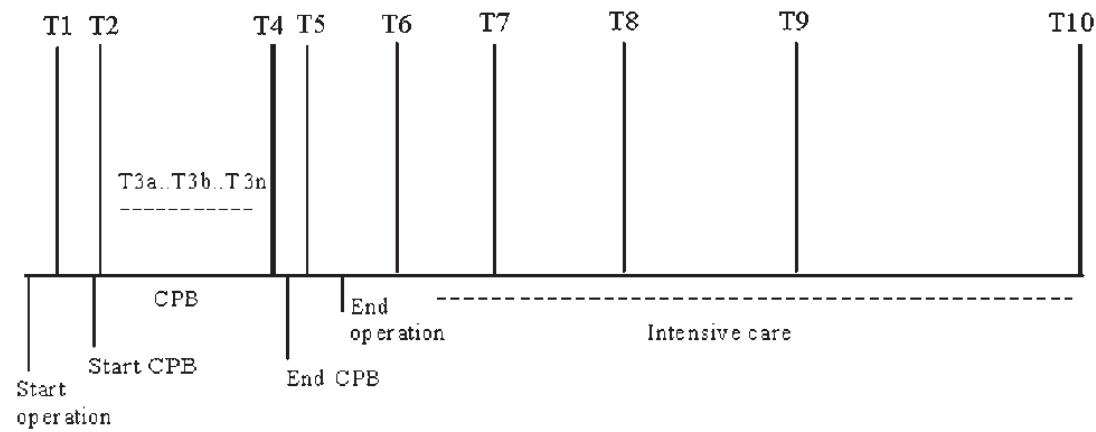

Figure 1. The study stages and their relation to the perioperative events. T1 - before systemic heparinization; start of CPB (T2); every 20 min of bypass (T3a...Tn); before removal of the aortic crossclamp (T4); 15 min after protamine infusion (T5); 2, 4, 8, 12, and $18 \mathrm{~h}$ after the end of operation (T6... T10).

Haemodynamic measurements, arterial and mixed venous blood samples were taken at 10 time intervals during surgery and up to $18 \mathrm{~h}$ in the postoperative period (Figure 1). Haemodynamic measurements consisted of arterial blood pressure, central venous pressure, and cardiac output, measured by the thermodilution method. The blood flow rate during total bypass was used for oxygen transport calculations in place of cardiac output. At all time periods, we also collected blood for measurement of haemoglobin concentration, arterial and mixed venous oxygen tension and saturation (ABL4; Radiometer, Copenhagen, Denmark). Lactate and pyruvate concentrations in the blood were measured at all time periods, excluding T3a...Tn. The venous blood temperature during CPB and pulmonary artery temperature in all other periods were assumed to 
represent the 'mean core' temperature. During the study, special attention was given to simultaneous measurement of haemodynamic parameters and the collection of blood samples.

Formulae used to calculate oxygen transport and related parameters are given in Appendix.

Linear regression analysis was applied to express the oxygen consumption as a function of the oxygen delivery and body temperature. Wilcoxon matched- pairs signed-ranks tests were used to determine whether the changes in oxygen uptake and related variables were significant. All statistical analyses were performed with SPSS 7.5 for Windows. A p value of less than 0.05 was considered significant. All values in the tables and the text are presented as mean \pm SD.

\section{Results}

The characteristics of the patients enrolled in the study are presented in Table 1. All patients were haemodynamically stable after surgery, i.e., during the $18 \mathrm{~h}$ of the study period. They all were awake and most of them were extubated at $12 \mathrm{~h}$ post-surgery. The mean time to extubation was $12 \mathrm{~h}$, with a range from 5 to $17 \mathrm{~h}$ after surgery. Two patients had a short period of atrial fibrillation treated by medication.

Table 1 Characteristics of patients and operation conditions $(n=15)$

\begin{tabular}{lc}
\hline Parameter & Value (mean \pm SD) \\
\hline Age (years) & $61.1 \pm 8.9$ \\
Male/Female & $12 / 3$ \\
BSA $\left(\mathrm{m}^{2}\right)^{*}$ & $1.90 \pm 0.15$ \\
Duration of CPB $(\mathrm{min})$ & $77.9 \pm 23.4$ \\
Crossclamp time $(\mathrm{min})$ & $49.9 \pm 18.8$ \\
Time to extubation $(\mathrm{min})$ & $721 \pm 183$ \\
\hline
\end{tabular}

*BSA=body surface area.

The systemic vascular resistance (SVR) was in the physiological range throughout the study period (Table 2). During the initiation of CPB, the SVR declined (from 1157.9 $\pm 195.1 \mathrm{dyn} \cdot \mathrm{s} / \mathrm{cm}^{5}$ at T1 to $924.7 \pm 213.7 \mathrm{dyn} \cdot \mathrm{s} / \mathrm{cm}^{5}$ at $\left.\mathrm{T} 2, \mathrm{p}<0.05\right)$. This, together with the decrease in blood flow, leads to a sharp lowering of the mean arterial pressure (from $78.97 \pm 8.43 \mathrm{mmHg}$ at $\mathrm{T} 1$ to $56.27 \pm 13.36 \mathrm{mmHg}$ at $\mathrm{T} 2, \mathrm{p}<0.001$ ). Later, during cooling, the SVR rose to the pre-perfusion level or higher. However, with the initiation of rewarming (T4), the vascular resistance started to decline and reached its lowest value after the end of perfusion (T5). A tendency to low vascular resistance was observed during the first 18 postoperative hours in each patient. At the same time, the 
mean arterial pressure was around $70 \mathrm{mmHg}$ because of a relatively high cardiac outoutput $\left(2.7-3.5 \mathrm{l} / \mathrm{min} / \mathrm{m}^{2}\right)$.

Table 2 Haemodynamic characteristics before, during, and up to $18 \mathrm{~h}$ after coronary bypass operation ( $\mathrm{n}=15$ patients)

\begin{tabular}{lccc}
\hline & $\begin{array}{c}\text { Mean arterial blood } \\
\text { pressure }(\mathrm{mmHg})\end{array}$ & $\begin{array}{c}\text { Blood flow index } \\
\left(1 / \mathrm{min} / \mathrm{m}^{2}\right)\end{array}$ & $\begin{array}{c}\text { Systemic vascular } \\
\text { resistance }\left(\mathrm{dyn} \cdot \mathrm{s} / \mathrm{cm}^{5}\right)\end{array}$ \\
\hline T1 & $78.97 \pm 8.43^{+}$ & $2.67 \pm 0.36^{*}$ & $1157.9 \pm 195.1^{*}$ \\
T2 & $56.27 \pm 13.36^{*}$ & $2.41 \pm 0.08$ & $924.7 \pm 213.7^{*}$ \\
T3a & $67.33 \pm 10.51^{*}$ & $2.35 \pm 0.20$ & $1148.7 \pm 143.4^{*}$ \\
T3b & $80.8 \pm 7.25$ & $2.37 \pm 0.11$ & $1315.1 \pm 154.6$ \\
T4 & $70.78 \pm 12.95$ & $2.41 \pm 0.21^{*}$ & $1171.3<194.8^{*}$ \\
T5 & $70.20 \pm 6.86$ & $3.09 \pm 0.75$ & $893.5 \pm 271.4^{*}$ \\
T6 & $74.37 \pm 8.54^{*}$ & $2.70 \pm 0.46^{*}$ & $1110.2 \pm 261.1$ \\
T7 & $68.6 \pm 9.48$ & $3.04 \pm 0.43$ & $900.4 \pm 225.7$ \\
T8 & $77.27 \pm 14.34$ & $3.45 \pm 0.75$ & $912.0 \pm 298.6$ \\
T9 & $70.87 \pm 12.40$ & $3.14 \pm 0.48$ & $876.9 \pm 220.6^{*}$ \\
T10 & $75.86 \pm 9.64$ & $3.00 \pm 0.40$ & $917.3 \pm 354.5$ \\
\hline
\end{tabular}

${ }^{*} p<0.05$ compared with next interval. ${ }^{+} p<0.01$ compared with next interval.

Oxygen delivery $\left(\mathrm{DO}_{2}\right)$ in the patients (Figure 2 ) was significantly above the critical level at the start of operation $(p<0.001)$ and during the major part of the CPB $(p<0.05, T 2$, $\mathrm{T} 3 \mathrm{a}, \mathrm{T} 3 \mathrm{~b}$ ). However, before removal of the aortic cross clamp (T4), the oxygen delivery rate entered the estimated critical area $\left(263.1 \pm 22.5\right.$ versus $243.5 \pm 37.3 \mathrm{ml} / \mathrm{min} / \mathrm{m}^{2}, \mathrm{p}$ $>0.05$ ) and also, the oxygen delivery decreased, close to a critical value at 2,12 , and 18 $h$ after the end of operation (T6, T9, and T10 respectively, $p>0.05)$.

The mean value of the oxygen consumption in this group of patients (Figure 3 ) was in the range of the expected oxygen consumption during surgery and up to $18 \mathrm{~h}$ after $(p>0.05)$. The oxygen extraction ratio $\left(\mathrm{O}_{2} E R\right)$ during the study period was lower than the critical value. Although the mean value of $\mathrm{O}_{2} \mathrm{ER}$ at the start of the operation and during CPB was relatively low $(20.8 \pm 5.1 \%, \mathrm{~T} 2)$, it began to rise at the end of surgery and reached its maximum at $12-18 \mathrm{~h}$ after operation $(31.5 \pm 9.4 \%$ and $30.1 \pm$ $6.1 \%$, T9 and T10, respectively). The difference between the expected and the measured oxygen consumption plotted against the time between two sample points gives the oxygen consumption deficit time curve. The mean value of the consumption deficit was close to zero during the study period.

The mean value of the net oxygen debt to the end of CPB (T1...T5) was $418.4 \pm$ $678.2 \mathrm{ml} \mathrm{O} / \mathrm{m}^{2}$ and increased to $710 \pm 1068.2 \mathrm{ml} \mathrm{O}_{2} / \mathrm{m}^{2}$ at the end of surgery (T1...T6). The mean value of oxygen consumption changed parallel to the body temperature. The minimum values of both parameters were observed during CPB (T3a and T3b). The 
$\mathrm{VO}_{2}$ reached a maximum at $8 \mathrm{~h}$ after surgery (T8). The body temperature reached its value $\left(38.22 \pm 0.47^{\circ} \mathrm{C}\right)$ at the same time. The regression analysis from pooled data showed a high exponential correlation between oxygen consumption rate and body temperature (Figure $4 ; \mathrm{VO}_{2}=1.3685 \cdot \exp ^{\left(0.1155 \cdot \cdot^{\circ} \mathrm{C}\right)}, \mathrm{r}^{2}=0.65, \mathrm{p}<0.001$ ).

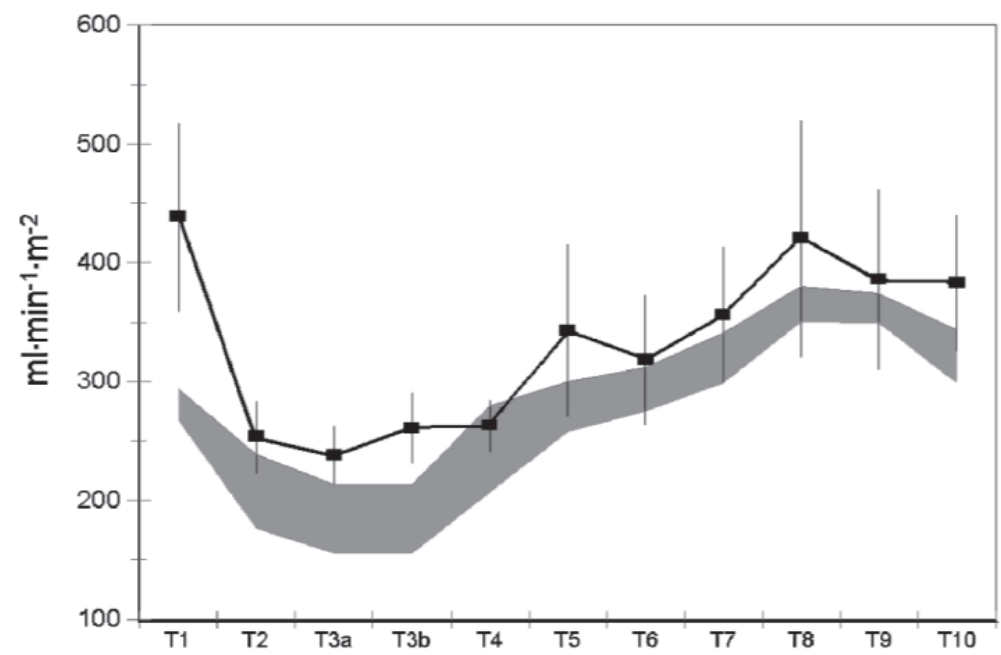

Figure 2 Oxygen delivery before, during, and up to $18 \mathrm{~h}$ after coronary bypass operation. The grey area is the critical level of oxygen delivery.

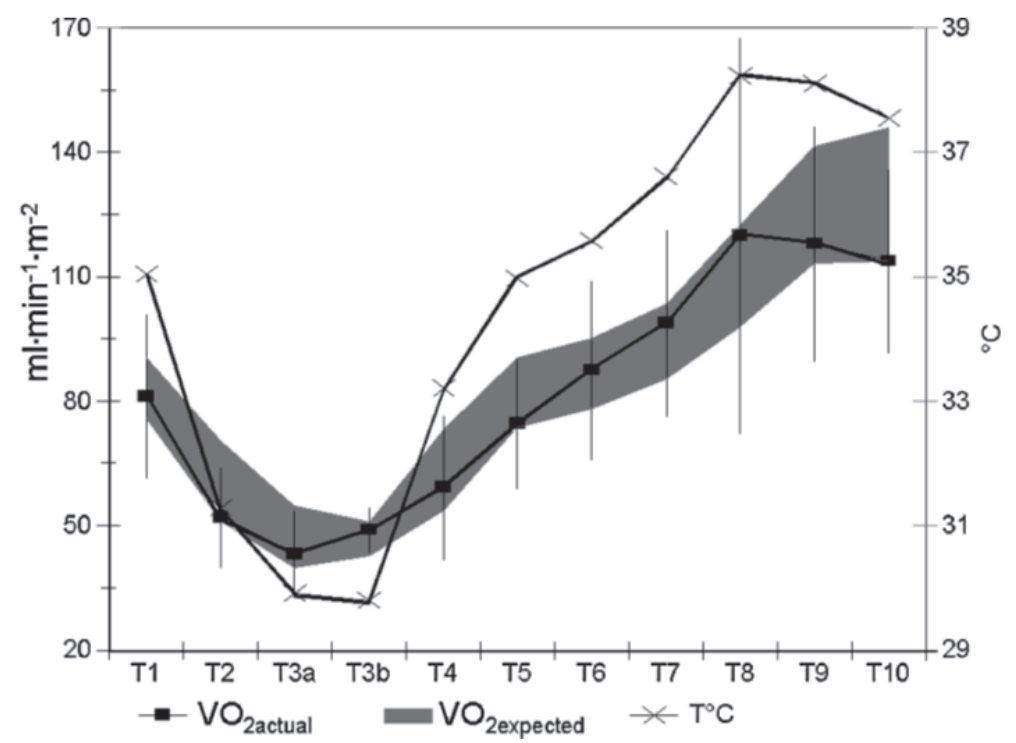

Figure 3. Oxygen consumption before, during, and up to $18 \mathrm{~h}$ after coronary bypass operation. The grey area is the expected level of oxygen consumption ( $p>0.05$ for all samples points). 


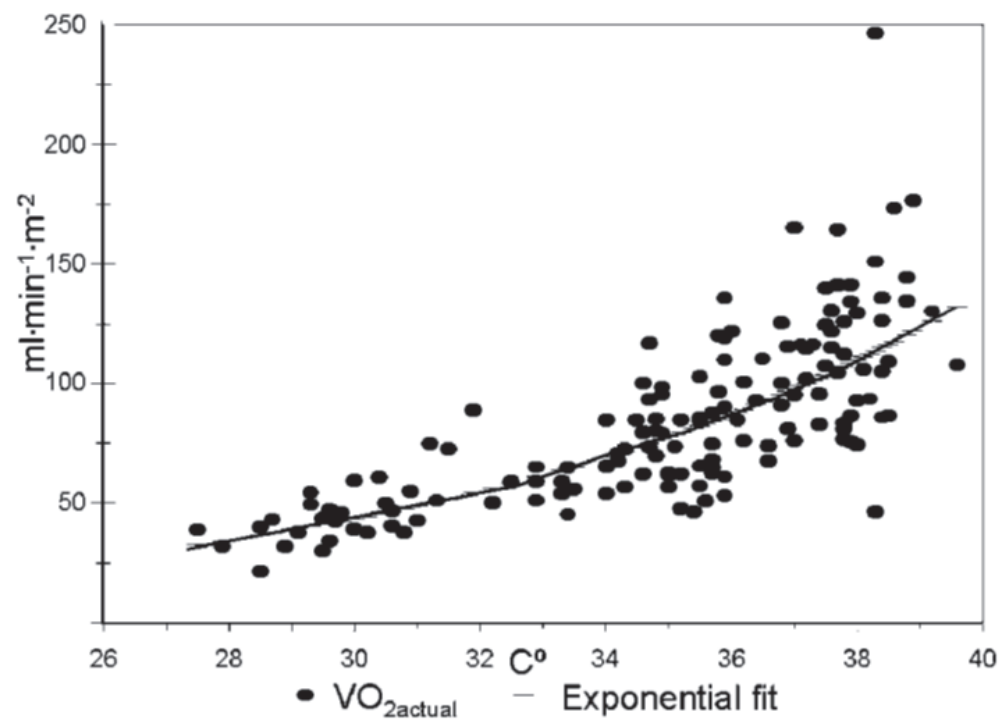

Figure 4 Whole body temperature and oxygen consumption pooled from all study periods (T1...T10).

The oxygen consumption was also related to the oxygen delivery rate. The regression analysis for the pooled data showed a linear relationship between $\mathrm{DO}_{2}$ and $\mathrm{VO}_{2}: \mathrm{VO}_{2}$ $=0.27 \cdot \mathrm{DO}_{2}-6.27, \mathrm{r}^{2}=0.49, \mathrm{p}<0.01$. However, the regression analysis for each study period failed to show any significant relation between $\mathrm{DO}_{2}$ and $\mathrm{VO}_{2}$ during surgery (T1...T5) and 8 and $12 \mathrm{~h}$ after operation (T9, T10). These two parameters were statistically significantly different only during the first hours after surgery (at T6, $r^{2}=0.57, p<0.001 ;$ at T7, $r^{2}=0.36, p<0.01 ;$ at T8, $r^{2}=0.715, p<0.001$ ).

Plasma lactate and pyruvate levels did not exceed the physiological ranges in any patient at any study time interval (Table 3). During the initiation of CPB the plasma lactate concentration significantly increased and reached a plateau after 20-30 min, after which it remained unchanged until the end of the surgery. Two hours later (T6), the lactate concentration had already decreased to the pre-bypass level. The PVA concentration was increased significantly after $60 \mathrm{~min}$ of $\mathrm{CPB}$, compared to the prebypass level $(121.0 \pm 44.9 \mathrm{mmol} / \mathrm{l}$ at T4 and $105.7 \pm 41.5 \mathrm{mmol} / \mathrm{l}$ at T1, $\mathrm{p}<0.05)$. In the postoperative period, up to $18 \mathrm{~h}$, the mean value of the PVA concentration did not change significantly.

The LA/PVA ratio dramatically increased during the initiation of CPB (from $9.87 \pm$ 2.43 at $\mathrm{T} 1$ to $12.08 \pm 1.51$ at $\mathrm{T} 2, \mathrm{p}<0.05$ ). The mean value of the LA/PVA ratio was elevated (more than 10x) during surgery. However, due to lowering of the plasma lactate concentration during the first $2 \mathrm{~h}$ in the postoperative period, the LA/PVA ratio decreased to normal values. 
The mixed venous $\mathrm{pH}$ also decreased during the initiation of $\mathrm{CPB}$, but stayed in the normal range during the entire study (Table 3 ).

Table $3 \mathrm{pH}$, lactate, pyruvate, and lactate/pyruvate ratio before, during, and up to $18 \mathrm{~h}$ after coronary bypass operation ( $\mathrm{n}=15$ patients)

\begin{tabular}{lllll}
\hline & pHv & LA $(\mathrm{mmol} / \mathrm{l})$ & PVA $(\mathrm{mol} / \mathrm{l})$ & LA/PVA \\
\hline T1 & $7.39 \pm 0.02^{+}$ & $1.00 \pm 0.39^{+}$ & $105.7 \pm 41.5$ & $9.87 \pm 2.43^{*}$ \\
T2 & $7.36 \pm 0.02$ & $1.19 \pm 0.46$ & $98.1 \pm 34.9^{\dagger}$ & $12.08 \pm 1.51$ \\
T3a & $7.34 \pm 0.04$ & $1.43 \pm 0.29$ & - & - \\
T3b & $7.35 \pm 0.04$ & $1.40 \pm 0.42$ & - & - \\
T4 & $7.35 \pm 0.04$ & $1.41 \pm 0.44$ & $121.0 \pm 44.9$ & $12.03 \pm 1.5^{*}$ \\
T5 & $7.36 \pm 0.04^{*}$ & $1.41 \pm 0.38^{*}$ & $129.3 \pm 37.6$ & $11.11 \pm 1.95^{*}$ \\
T6 & $7.40 \pm 0.05$ & $1.04 \pm 0.33$ & $111.7 \pm 46.5$ & $9.71 \pm 2.03$ \\
T7 & $7.39 \pm 0.04$ & $1.02 \pm 0.40$ & $113.5 \pm 49.2$ & $9.27 \pm 1.31^{*}$ \\
T8 & $7.36 \pm 0.04$ & $1.01 \pm 0.35$ & $133.7 \pm 57.6$ & $8.04 \pm 1.91$ \\
T9 & $7.36 \pm 0.04$ & $1.11 \pm 0.45$ & $145.7 \pm 67.4$ & $7.92 \pm 1.67$ \\
T10 & $7.35 \pm 0.03$ & $1.39 \pm 0.66$ & $155.6 \pm 75.0$ & $9.45 \pm 3.26$ \\
\hline
\end{tabular}

$\mathrm{pHv}$, mixed venous $\mathrm{pH}$; LA, plasma lactate; PVA, plasma pyruvate; LA/PVA, lactate/pyruvate ratio. ${ }^{*} \mathrm{p}<0.05$ compared with next interval. ${ }^{+} p<0.01$ compared with next interval.

\section{Discussion}

Optimal oxygen delivery and consumption in the perioperative period are essential in order to reduce immediate morbidity and mortality after open-heart surgery [2]. If oxygen delivery is below a critical level, the oxygen consumption will simultaneously decrease linearly. In this situation, the oxygen delivery is inadequate to prevent tissue hypoxia and development of the oxygen debt. Oxygen debt is considered as an important factor in determining the outcome of surgical patients, as well as critically ill patients [2, 8, 14 -16]. However, most of these reports have been criticized because of their methodology $[12,13]$. There have also been a number of reports that refute the existence of supply dependence in critically ill patients or during surgery [12, 17 - 19].

Several clinical studies in high- risk surgical patients showed a biphasic response, with reduced oxygen consumption and reduced cardiac output during surgery followed by an increase of $\mathrm{CO}$ and $\mathrm{VO}_{2}$ in the postoperative period $[5,6,20]$. This biphasic response is independent of the type of operation, and represents the periods of accumulation and repayment of an oxygen debt. It appears that our data showed this biphasic response with a reduction of oxygen delivery and consumption during surgery and, subsequently, an increase in the postoperative period. However, comparison of these parameters with the expected individual delivery and consumption disproves this 
assumption (Figures 2 and 3). At all time intervals, the mean values of $\mathrm{DO}_{2}$ and $\mathrm{VO}_{2}$ were in the expected range when corrected for the patient's body temperature, level of anaesthesia, and muscle relaxation. Also, the oxygen extraction ratio was lower than reported critical values [21].

However, from the first hours after surgery, the oxygen extraction ratio began to rise and reached its maximum at $12-18 \mathrm{~h}$ after operation $(31.5 \pm 9.4 \%$ at T9 and $30.1 \pm$ $6.1 \%$ at $\mathrm{T} 10)$. This could indicate some stress in the oxygen transport system, probably related to the increase of the body temperature and the extubation of the patient.

One other recognized indicator of oxygen debt is the $\mathrm{VO}_{2}$ dependency on the $\mathrm{DO}_{2}$. Some reports are presenting a strong association between $\mathrm{VO}_{2}$ and $\mathrm{DO}_{2}$ in cardiac surgical patients $[7,22]$. In contrast to these findings, we could not reveal any correlation between $\mathrm{VO}_{2}$ and $\mathrm{DO}_{2}$ during $\mathrm{CPB}$. Significant $\mathrm{VO}_{2}$ dependence on the $\mathrm{DO}_{2}$ was found only in the pooled data from the entire study. However, this $\mathrm{VO}_{2} / \mathrm{DO}_{2}$ relationship in a select subpopulation, such as the presented group of patients, may be a result of an artificial correlation due to a third type of mathematical coupling [23]. If a true relationship is to be found between $\mathrm{VO}_{2}$ and $\mathrm{DO}_{2}$, it must be determined by using an independently obtained $\mathrm{VO}_{2}$ from the expired gas analysis. Such a study was done by Myles et al. [18], and the authors failed to show any significant relationship between changes in $\mathrm{DO}_{2}$ and $\mathrm{VO}_{2}$ peri-operatively. Our results seem to demonstrate a leading role of body temperature changes in relation to the perioperative changes in the oxygen consumption rate. A peak in the $\mathrm{VO}_{2}$ was recorded at a time when the maximum body temperature occurred. Also, the pooled data showed a strong exponential correlation between the body temperature and the total oxygen consumption (Figure $4 ; r^{2}=0.65, p<0.001$ ).

Measurement of acidosis, base deficit, and blood lactate levels is providing more objective information. Lactate is an end product of anaerobic metabolism and is in a dynamic equilibrium with its precursor, pyruvate. The LA/PVA ratio is related to the redox state of the cell, which is a function, in part, of the adequacy of oxygen delivery [24]. The ratio of serum lactate to pyruvate concentrations in arterial blood is normally less or equal to 10:1. Lactate/pyruvate ratios $>10: 1$ suggest that the $\mathrm{DO}_{2}$ is inadequate to meet the metabolic demand [25]. However, newer data suggest that lactate could accumulate under aerobic conditions in clinical settings [24]. Calcium, insulin, and magnesium stimulate PDH phosphatase, which catalyzes phosphorylation of PDH and its deactivation, which consequently leads to formation of more lactate anions [24]. The washout of lactate from peripheral tissues [26, 27] and a decreased lactate clearance [10] can complicate even more the interpretation of intraoperative findings.

The rise of the LA/PVA ratio just after the initiation of the CPB could indicate impaired tissue perfusion, although these findings $(9.87 \pm 2.43$ at T1 and $12.08 \pm 1.51$ at $T 2, p<0.05)$ are more likely related to the sharp changes in the haemodynamics 
rather than switching to anaerobic metabolism. Haemodilution of $25-35 \%$ after the mixing of the prime $(1600 \mathrm{ml})$ with the patient's blood is the most likely explanation of the significant decrease in the PVA concentration (Table $3 ; p<0.001$ ). On the other hand, lactate concentration does increase in the early phase of CPB, but this increase did not exceed the normal levels of lactate concentration $(2 \mathrm{mmol} / \mathrm{l})$. Common vasoplegia during the first 10 - 15 min of CPB, together with haemodilution, could increase the washout of lactate from previously hypo-perfused tissues [26, 27]. There is one more mechanism that could be involved in maintaining the relative excess of lactate during cardiac surgery, an intraoperative decrease of lactate clearance. The myocardium, which is an important consumer of lactate $[24,28]$, is excluded from the circulation during most of the surgery time. The absence of any significant degree of metabolic acidosis during our study may additionally confirm a lack of anaerobic metabolism and oxygen debt during surgery and up to $18 \mathrm{~h}$ thereafter.

The analysis of data reveals the fact that the oxygen debt theory could not explain our findings. Alternatively, our data indicate that the changes in body temperature during and after surgery in the studied group of patients create the illusion of biphasic response with a reduction of oxygen delivery and consumption during surgery and an increase in the postoperative period.

\section{Conclusion}

We conclude that, in the studied group of patients, systemic oxygenation was neither impaired during CPB, nor in the first $18 \mathrm{~h}$ after surgery. Some stress of the oxygen transport system was found in the period $12-18 \mathrm{~h}$ after surgery, which is probably related to the increased body temperature and extubation of the patients.

\section{Acknowledgements}

We thank Lou Donsellaar, Clinical Chemical Laboratory of University Hospital Maastricht, and Cees Visser, Department of Extra Corporeal Circulation of University Hospital Maastricht, for their assistance and valuable comments. The authors would like to thank Dr. Chris Lawrence for reading and correcting the manuscript. 


\section{References}

1. Chiara O, Giomarelli PP, Biagioli B, Rosi R, Gattinoni L. Hypermetabolic response after hypothermic cardiopulmonary bypass. Crit Care Med 1987; 15:995-1000.

2. Shoemaker WC, Appel PL, Kram HB. Oxygen transport measurements to evaluate tissue perfusion and titrate therapy: dobutamine and dopamine effects. Crit Care Med 1991; 19:672-688.

3. Utoh J, Moriyama S, Okamoto K, Kunitomo R, Hara M, Kitamura N. The effects of cardiopulmonary bypass on postoperative oxygen metabolism. Surg Today 1999; 29:28-33.

4. Parolari A, Alamanni F, Gherli T et al. Cardiopulmonary bypass and oxygen consumption: oxygen delivery and hemodynamics. Ann Thorac Surg 1999; 67:1320-1327.

5. Waxman K, Lazrove S, Shoemaker WC. Physiologic responses to operation in high-risk surgical patients. Surgery Gynecol Obstet 1981; 152:633-638.

6. Shoemaker WC, Appel PL, Kram HB. Hemodynamic and oxygen transport responses in survivors and non-survivors of high-risk surgery. Crit Care Med 1993; 21:977-990.

7. Cavaliere F, Gennari A, Martinelli L, Zamparelli R, Schiavello R. The relationship between systemic oxygen uptake and delivery during moderate hypothermic cardiopulmonary bypass: critical values and effects of vasodilation by hydralazine. Perfusion 1995; 10:315-321.

8. Utoh J, Moriyama S, Kitamura N, Okamoto K. Recovery from metabolic impairments after hypothermic cardiopulmonary bypass: postoperative changes in arterial-venous carbon dioxide tension difference. Ann Thorac Cardiovasc Surg 1999; 5:27-30.

9. Pinsky MR, Schlichtig R. Regional oxygen delivery in oxygen supply-dependent states. Intensive Care Med 1990; 16:S169-S171.

10. Vincent JL. The relationship between oxygen demand, oxygen uptake, and oxygen supply. Intensive Care Med 1990; 16:S145-S148.

11. Komatsu T, Shibutani K, Okamoto $\mathrm{K}$ et al. Critical level of oxygen delivery after cardiopulmonary bypass. Crit Care Med 1987; 15:194-197.

12. Manthous CA, Schumacker PT, Pohlman A et al. Absence of supply dependence of oxygen consumption in patients with septic shock. J Crit Care 1993; 8:203-211.

13. Hinds C, Watson D. Manipulating hemodynamics and oxygen transport in critically ill patients. N Engl J Med 1995; 333:1074-1075.

14. Naylor-Shepherd MF, Fuhs DW, Angaran DM. Oxygen homeostasis: theory, measurement, and therapeutic implications. DICP 1990; 24:1195-1203.

15. Shoemaker WC, Appel PL, Kram HB. Measurement of tissue perfusion by oxygen transport patterns in experimental shock and in high-risk surgical patients. Intensive Care Med 1990; 16:S135-S144.

16. Waxman K, Lorene S, Nolan RN, Shoemaker W. Sequential perioperative lactate determination: physiological and clinical implications. Crit Care Med 1982; 10:96-99.

17. Mira JP, Fabre JE, Baigorri F et al. Lack of oxygen supply dependency in patients with severe sepsis. A study of oxygen delivery increased by military antishock trouser and dobutamine. Chest 1994; 106:1524-1531.

18. Myles PS, McRae R, Ryder I, Hunt IO, Buckland MR. Association between oxygen delivery and consumption in patients undergoing cardiac surgery. Is there supply dependence? Anaesth Intensive Care 1996; 24:651-657.

19. Bacher A, Mayer N, Mittlboeck M, Zadrobilek E. Anaesthesia and systemic oxygenation. Acta Anaesthesiol Scand 1996; 40:869-875.

20. Hankeln KB, Senker R, Schwarten JB. Evaluation of prognostic indices based on hemodynamic and oxygen transport variables in shock patients with ARDS. Crit Care Med 1987; 15:1-5.

21. Van der Linden $P$, Gilbart E, Engelman E, Schmartz D, Vincent J. Effects of anesthetic agents on systemic critical $\mathrm{O}_{2}$ delivery. J Appl Physiol 1991; 71:83-93. 
22. Tulla H, Takala J, Alhava E, Huttunen H, Kari A. Hypermetabolism after coronary artery bypass. J Thorac Cardiovasc Surg 1991; 101:598-600.

23. Stratton H, Feustel PJ, Newell JC. Regression of calculated variables in the presence of shared measurement error. J Appl Physiol 1987; 62:2083-2093.

24. Singarajah C, Carlson RW. A review of the role of blood lactate measurements in the ICU. J Intensive Care Med 1998; 13:218-228.

25. Landow L. Splanchnic lactate production in cardiac surgery patients. Crit Care Med 1993; 21:S84-S91.

26. Niinikoski J, Laaksonen V, Meretoja O, Jalonen J, Inberg MV. Oxygen transport to tissue under normovolemic moderate and extreme hemodilution during coronary bypass operation. Ann Thorac Surg 1981; 31:134-143.

27. Laycock GJA, Alston RP. Propofol and hypothermic cardiopulmonary bypass. Vasodilation and enhanced metabolic protection? Anaesthesia 1992; 47:382-387.

28. Pietersen $\mathrm{H}$, Langenberg CJM, Geskes $\mathrm{G}$ et al. Myocardial substrate uptake and oxidation during and after routine cardiac surgery. J Thoracic Cardiovasc Surgery 1999; 118:71-80.

29. Riley JB, Heinemann SO, Cavanaugh DS. Technique to give relevance to calculate oxygen transfer during cardiopulmonary bypass. J Extra-Corpor Technol 1983; 15:35-40.

30. Christoforides C, Hedley-Whyte J. Effect of temperature and hemoglobin concentration on solubility of $\mathrm{O}_{2}$ in blood. J Appl Physiol 1960; 27:592-596.

31. Shibutani K, Komatsu T, Kubal K, Sanchala V, Kumar V, Bizzarri DV. Critical level of oxygen delivery in anesthetized man. Crit Care Med 1983; 11:640-643.

32. Lower HJ, Ernst EA. Use of closed circuit. The quantitative practice of anesthesia. Baltimore, MD: Williams \& Wilkins, 1981, p146-147.

33. Loer SA, Scheeren TW, Tarnow J. How much oxygen does the human lung consume? Anesthesiology 1997; 86:532-537. 


\section{Appendix}

The $\mathrm{DO}_{2}$ in each case was calculated as the product of arterial oxygen content $\left(\mathrm{ConO}_{2} \mathrm{a}\right.$, $\mathrm{ml} \mathrm{O}_{2} / 100 \mathrm{ml}$ blood) multiplied by the perfusion flow $\left(\mathrm{Cl}, \mathrm{l} / \mathrm{min} / \mathrm{m}^{2}\right)$ :

$$
\mathrm{DO}_{2}\left(\mathrm{ml} / \mathrm{min} / \mathrm{m}^{2}\right)=\mathrm{ConO}_{2} \mathrm{a} \cdot \mathrm{Cl} \cdot 10
$$

The oxygen content in blood is the sum of oxygen carried by haemoglobin and dissolved in plasma:

$\mathrm{ConO}_{2}=\mathrm{Hb} \cdot \mathrm{SO}_{2} \cdot 1.32+\mathrm{PO}_{2} \cdot \mathrm{ZO}_{2}$

where: $\mathrm{Hb}$ - haemoglobin content of blood ( $\mathrm{g} \%) ; \mathrm{SO}_{2}$ - oxygen saturation of blood $(\mathrm{U})$; 1.32 - binding coefficient; $\mathrm{PO}_{2}$ - oxygen partial pressure (atm); $\mathrm{ZO}_{2}$ - solubility coefficient of oxygen at actual blood temperature ( $\mathrm{ml}$ oxygen/100 $\mathrm{ml} \mathrm{blood}$ ).

The oxygen solubility coefficient $\left(\mathrm{ZO}_{2}\right)$ was computed using the regression equation published by Riley et al. [29] in 1983. This equation gives a strong correlation with measured values published by Christoforides and Hedley-Whyte [30] in 1960:

$\mathrm{ZO}_{2}=[(4 \cdot \mathrm{Hb}+346) \cdot \mathrm{T}+(130 \cdot \mathrm{Hb}+35000)] \cdot 0.0001 / 760$

where: $\mathrm{Hb}$ - haemoglobin content of blood (g\%); $\mathrm{T}$ - blood temperature $\left({ }^{\circ} \mathrm{C}\right)$.

The critical level of oxygen delivery $\left(\mathrm{DO}_{2} \mathrm{crit}\right)$ in normothermic anaesthesized patients was determined as $300-330 \mathrm{ml} / \mathrm{min} / \mathrm{m}^{2}$ [2, 11, 31]. The hypothermia during CPB exponentially decreases the tissue metabolic rate and correspondingly the oxygen consumption rate. It is logical to assume that the critical level of oxygen delivery changes with the decrease in tissue metabolic rate. The oxygen delivery of 330 $\mathrm{ml} / \mathrm{min} / \mathrm{m}^{2}$ was taken as a value of $\mathrm{DO}_{2} \mathrm{crit}$ for anaesthesized patients at $37^{\circ} \mathrm{C}$ body temperature. The regression equation (Equation 4) was used to compute the temperature correction coefficient:

Coef $=\exp ^{[(0.08329 \cdot T+1.5234) / 100)]}$

The last equation (Equation 4) was suggested by Riley et al. [29] in 1983. The individual value of the critical level of oxygen delivery was calculated for each patient according to the body temperature. The critical area of oxygen delivery for our group of patients was defined as an area between mean+SD (upper limit) and mean-SD (lower limit) of $\mathrm{DO}_{2}$ crit computed for each patient at correspondent study point. 
The $\mathrm{VO}_{2}$ in each case was calculated as a product of arterial - venous difference multiplied by the blood flow:

$\mathrm{VO}_{2}\left(\mathrm{ml} / \mathrm{min} / \mathrm{m}^{2}\right)=\left(\mathrm{ConO}_{2} \mathrm{a}-\mathrm{ConO}_{2} \mathrm{v}\right) \cdot \mathrm{Cl} \cdot 10$

The calculation of expected oxygen consumption was based on published results of large population studies of human basal metabolic rate. In this work, the linear equations derived by Riley et al. [29] were used for males:

$\mathrm{VO}_{2} \exp \left(\mathrm{ml} / \mathrm{min} / \mathrm{m}^{2}\right)=\exp ^{(0.003907 \cdot A+5.034)}$

for females

$\mathrm{VO}_{2} \exp \left(\mathrm{ml} / \mathrm{min} / \mathrm{m}^{2}\right)=\exp ^{(0.002806 \cdot A+4.8934)}$

where: A - age (years).

The induction of anaesthesia and muscle relaxation causes a decrease in whole body oxygen consumption to $80-85 \%$ from the expected due to the lowering of functional requirement [32]. Decreasing oxygen demand during CPB is also caused by induction of hypothermia. The effect of temperature on expected oxygen consumption was shown in Equation (4).

The myocardial oxygen consumption in adults at rest, according to non-published data collected by Loer et al. [33] (University Hospital Maastricht, 1998), is $5.3 \pm 0.23$ $\mathrm{ml} / \mathrm{min} / \mathrm{m}^{2}$ and the lungs consume about $5 \%$ of the whole body oxygen uptake. Excluding the myocardium and lungs from the circulation explains up to $10 \%$ of the decrease in whole body oxygen consumption during the cross clamp time.

The final value of expected oxygen consumption during total bypass appears to be $25-30 \%$ lower than that derived using Equation (6) or Equation (7). The expected level of oxygen consumption for our group of patients was defined as an area between mean+SD (upper limit) and mean-SD (lower limit) of $\mathrm{VO}_{2}$ exp computed for each patient at the corresponding study point.

The oxygen debt was calculated from the difference between the actual measured VO2 and the individual $\mathrm{O}_{2}$ requirements corrected for both anaesthesia [32] and temperature [29]. Then, the net cumulative VO2 deficit was computed as an integrated area under the $\mathrm{VO}_{2}$ deficit-time curve [2]. 



\section{CHAPTER 4}

\section{The effect of oxygenator mechanical}

characteristics on energy transfer during clinical cardiopulmonary bypass

YM Ganushchak, KD Reesink, PW Weerwind and JG Maessen

Published in Perfusion 2011; 26:39-44. 


\section{Abstract}

The hollow-fibre oxygenator is a key component of any extracorporeal circuit used to provide cardiopulmonary bypass (CPB) during open-heart surgery. Since the oxygenator is placed downstream the pump, the energy losses over it have a direct impact on the quality of pulsatile pressure and flow waveforms. The objective of this study was to describe the effects of hydrodynamic characteristics of oxygenator on energy transfer during pulsatile, normothermic CPB.

Twenty-three adult patients scheduled for coronary bypass surgery were randomly divided in two groups using either an oxygenator (group 1) with a relatively high-resistance, low-compliance $\left(2079 \pm 148 \mathrm{dyn} \cdot \mathrm{s} \cdot \mathrm{cm}^{-5}\right.$ and $0.00348 \pm 0.00071$ $\mathrm{ml} \cdot \mathrm{mmHg}^{-1}$, respectively) or an oxygenator (group 2) with a relatively low-resistance, high-compliance $\left(884 \pm 464\right.$ dyn $\cdot \mathrm{s} \cdot \mathrm{cm}^{-5}$ and $0.01325 \pm 0.00161 \mathrm{ml} \cdot \mathrm{mmHg}^{-1}$, respectively). During perfusion, pre- and post-oxygenator pressures, radial artery pressure, and blood flow were recorded simultaneously.

A 32\% decline of mean pressure was observed in group 1 and a 16\% decline in group $2(p<0.0001)$. Another decrease by approximately $73 \%$ in mean pressure in the rest of the perfusion system was noted in both groups. The mean radial artery pressure did not differ between the groups ( $74 \pm 6 \mathrm{mmHg}$ in group 1 and $73 \pm 6 \mathrm{mmHg}$ in group 2, $p=0.608)$. Although lower total energy transfer indices were noticed through the low-resistance oxygenator (group 2), both oxygenators showed a decrease of the generated pump oscillatory energy of approximately $50 \%$.

Despite the differences in resistance and compliance of the hollow-fibre oxygenators used, both oxygenators cause a comparable loss of generated oscillatory energy. Exclusion of the oxygenator downstream the pulsatile pump would improve energy transfer during CPB. 


\section{Introduction}

The debate on pulsatile flow during cardiopulmonary bypass (CPB) has continued for more than half a century. A recent PubMed database search on the topic revealed 2,816 articles between 1967 and 2006 [1]. Although the subject has been discussed frequently during the past decades, results of the associated studies are controversial [2-5]. There are several reasons for dichotomy of results in comparative studies. The most important reason is methodological in nature. Many studies lack precise quantification of pressure and flow waveforms [3-8]. The broadly used term 'pulsatile $\mathrm{CPB}^{\prime}$ in clinical trials is most often characterized only by heart-lung machine settings or by arterial pulse pressure, not by objective quantitative measures. Moreover, the enormous variety of blood flow indices, flow dynamics, and temperature regimes used in these studies, make the results often non-comparable and incoherent. Variations due to differences in characteristics and condition of the systemic vascular bed of patients are rarely assessed and, therefore, limit comparison even more.

Another reason for the lukewarm reception and skepticism of pulsatile CPB is the limited efficiency of the pumps used. For example, a roller pump is able to produce only $12.4 \%$ pulsatile power output compared to the heart [9]. Furthermore, in clinical practice a pulsatile regime is often not employed to its best advantage [10]. The complexity of the problem is also in the obvious conflict of interests of pulsatile flow and membrane oxygenation [11], and pulsatile flow and size of the arterial cannula [12] or pulsatile flow and length of the arterial line [13]. In addition, it is possible that, considering the complex physiological effects of pulsation, not only stroke volume is important but also the flow waveform (i.e. acceleration time and peak flow).

The hollow-fibre membrane oxygenator is a key component of any extracorporeal circuit used to provide CPB during open-heart surgery. Oxygenators are placed downstream from the arterial pump so that blood is pushed through the oxygenator. As a result, its mechanical properties have a direct impact on the quality of the pulsatile pressure and flow waveforms [14-16]. Some oxygenators dampen the pulse wave to a significant extent $[11,17]$. It is generally accepted that an oxygenator with a lower pressure drop results in better flow pulsatility [16]. The aim of the present study was to describe the transmission of energy through two distinct hollow-fiber oxygenators during pulsatile, normothermic CPB.

\section{Materials and methods}

Twenty-three adult patients undergoing elective coronary bypass surgery were included in the study, and were randomly assigned to two groups. The study protocol 
was approved by the Medical Ethical Committee of the Maastricht University Medical Centre. Written informed consent was obtained from all patients included. The study was registered in the Dutch Trial Register, trial number NTR1346.

In group 1 ( $n=12)$, a high-resistant, low-compliant hollow-fibre oxygenator (Capiox SX18, Terumo Cardiovascular Systems, Tokyo, Japan) was used. Group $2(n=11)$ was assigned to a low-resistant, high-compliant hollow-fibre oxygenator (Quadrox BEHMO 2000, Maquet Cardiopulmonary AG, Hirrlingen, Germany). In all cases, the extracorporeal system consisted of a Sorin S3 heart-lung machine (Sorin, S.p.A. Milano, Italy), a Bioline coated custom tubing pack (Maquet Cardiopulmonary AG), a 1/2-inch medical grade silicone arterial pump tubing, an arterial line filter (Leukoguard-6, Pall, East Hills, NY, USA), collapsible venous reservoir (JVR 1900, Maquet Cardiopulmonary AG), and a cardiotomy reservoir (Capiox SX hard-shell reservoir, Terumo Cardiovascular Systems). Occlusion setting of the arterial roller pump was set statically against a backpressure of $260 \mathrm{mmHg}$. The occlusion setting was verified before every use. Central cannulation was applied in all cases.

The instantaneous flow at the inlet and outlet of the oxygenator was measured using ultrasonic clamp-on flow probes (H9XL, Transonic Systems Inc., Ithaca NY, USA). Pressure was measured at the inlet and outlet of the oxygenator close to the flow probes and in the radial artery, using pressure transducers (PX604, TruWave, Edwards Lifesciences, Irvine, CA 92614, USA). Electronic data were acquired with a sampling frequency of $250 \mathrm{~Hz}$, using a programmable PC-based acquisition system (MPAQ amplifier with IDEEQ software, Instrument Development Engineering \& Evaluation, Maastricht University Medical Centre, Maastricht, the Netherlands).

The perfusion system was primed with $1,500 \mathrm{ml}$ of colloidal solution. The management of normothermic perfusion was standardized by clinical practice. The mean arterial pressure was maintained around $75 \mathrm{mmHg}$ with infusion of phenylephrine, if necessary. Pulsatile perfusion was initiated after aorta clamping. Pulsatile flow was set to $5.0 \mathrm{Imin}^{-1}$ with a frequency of 72 beats per minute, a base flow of $28 \%\left(1.4 \mathrm{lmin}^{-1}\right)$, and a pulse width of $0.42 \mathrm{~s}$ ( $50 \%$ duty cycle). The pressure and flow waveform data were used to calculate quantitative parameters for the description of pulsatile perfusion. All parameters were computed and averaged over five-minute time intervals.

\section{Mechanical oxygenator characteristics}

\section{Compliance}

Compliance describes the volume buffering capacity of a distensible compartment and is expressed as the ratio of the change in volume $(\Delta \mathrm{V})$ divided by the change in pressure $(\Delta p)[18]$. 
The static compliance of oxygenators used in this study was computed from the pressure-volume relation. Pressure-volume relations were obtained in vitro after careful priming of the oxygenators. The pressure in the oxygenator was first increased from 0 to $1,000 \mathrm{mmHg}$ by injection of $0.9 \%$ sodium chloride solution in steps of $1 \mathrm{ml}$. Then the pressure was stepped down back to $0 \mathrm{mmHg}$. Compliance is calculated as:

$\mathrm{C}=\Delta \mathrm{V} / \Delta \mathrm{p}$

with $\mathrm{C}$, compliance $\left(\mathrm{ml} . \mathrm{mmHg}^{-1}\right) ; \Delta \mathrm{V}$, volume change $(\mathrm{ml}) ; \Delta \mathrm{p}$, pressure change ( $\mathrm{mmHg}$ ).

The Quadrox BEHMO 2000 oxygenator had a significantly higher static compliance than the Capiox SX 18 oxygenator $\left(0.01325 \pm 0.00161 \mathrm{ml} \cdot \mathrm{mmHg}^{-1}\right.$ versus $0.00348 \pm$ $\left.0.00071 \mathrm{ml} \cdot \mathrm{mmHg}^{-1}, \mathrm{p}<0.0001\right)$.

\section{Resistance}

Resistance is computed from the clinical data as the mean pressure drop divided by the mean flow through the oxygenator, as:

$R=79.9 \cdot\left(p_{0}-p_{1}\right) / Q$

with $\mathrm{R}$, hydrodynamic resistance $\left(\right.$ dyn $\left.\cdot \mathrm{s} \cdot \mathrm{cm}^{-5}\right) ; \mathrm{p}_{0}$, average inlet pressure $(\mathrm{mmHg}) ; \mathrm{p}_{1}$, average outlet pressure $(\mathrm{mmHg}) ; 79.9$, is the constant to convert from millimetres of mercury to dynes per square centimetres and flow from I per min to $\mathrm{ml}$ per second $(1,332 \cdot 60 / 1,000) ; Q$, average flow $\left(1 \mathrm{~min}^{-1}\right)$. The resistance of the Capiox SX 18 was significantly higher than the resistance of the Quadrox BEHMO $2000(2,079 \pm 148$ dyn $\cdot \mathrm{s} \cdot \mathrm{cm}^{-5}$ and $884 \pm 464$ dyn $\cdot \mathrm{s} \cdot \mathrm{cm}^{-5}$, respectively, $\left.\mathrm{p}<0.0001\right)$.

\section{Quantification of pulsatile perfusion}

\section{Energy Equivalent Pressure}

Shepard's energy equivalent pressure (EEP) is defined as hemodynamic energy per unit volume of fluid pumped. EEP was computed as the ratio of the area beneath the hemodynamic power curve and the pump flow curve during each pulse cycle $[3,19$ 22]:

$$
\mathrm{EEP}=\int_{0}^{t} Q(\tau) p(\tau) d \tau / \int_{0}^{t} Q(\tau) d \tau
$$


with $Q$, pump flow rate $\left(l \mathrm{~min}^{-1}\right) ; \mathrm{p}$, arterial pressure $(\mathrm{mmHg})$. The time integrals are over a single pulse cycle. EEP is expressed in $\mathrm{mmHg}$.

\section{Surplus hemodynamic energy}

Surplus hemodynamic energy (SHE) is the additional energy due to pulsatility in pressure or flow. SHE is defined as $[21,24]$ :

$\mathrm{SHE}(\mathrm{mmHg})=\left(\mathrm{EEP}-\mathrm{p}_{\text {mean }}\right)$

with EEP, energy equivalent pressure $(\mathrm{mmHg})$; $p_{\text {mean }}$, mean pressure $(\mathrm{mmHg})$. Similarly to fractional pulse pressure $[25,26]$, we computed the fractional energy excess (FEE) as the ratio of the SHE and $p_{\text {mean }}$.

\section{Pressure energy}

Pressure energy is a kind of potential energy. Potential energy per unit time is a product of the pressure and the volume rate of blood flow at any instant [27]. The total pressure energy is calculated as the area beneath the hemodynamic power curve $[3,19,28]$ :

$$
W t=\frac{1}{T} \int_{0}^{T} Q(\tau) \times p(\tau) d \tau
$$

where $\mathrm{W}_{t}$, total pressure energy $\left(\mathrm{W} \cdot \mathrm{s}^{-1}\right) ; \mathrm{T}$, the period for the numeric evaluation of the integral; $Q(t)$, the instantaneous measured flow rate $\left(l \mathrm{~min}^{-1}\right) ; \mathrm{p}(\mathrm{t})$, instantaneous pressure $(\mathrm{mmHg})$.

Two components of total pressure energy are discriminated: the steady component $W_{s}$ (the energy that would exist if there were no oscillations around the mean) and the oscillatory (pulsatile) component $W_{0}$.

$W_{s}$ is calculated by multiplying mean pressure and mean flow $[3,18,27]$ :

$W_{s}=p_{m} \cdot Q_{m}$

with $\mathrm{p}_{\mathrm{m}}$, mean pressure $(\mathrm{mmHg}) ; \mathrm{Q}_{\mathrm{m}}$, mean flow ( $\left.\mathrm{l} / \mathrm{min}\right)$.

The oscillatory pressure energy is calculated as the difference between the total pressure energy and the steady component:

$\mathrm{W}_{o}=\mathrm{W}_{t}-\mathrm{W}_{\mathrm{s}}$

with $\mathrm{W}_{o}$, oscillatory pressure energy $\left(\mathrm{W} \cdot \mathrm{s}^{-1}\right) ; \mathrm{W}_{t}$, total pressure energy $\left(\mathrm{W} \cdot \mathrm{s}^{-1}\right) ; \mathrm{W}_{\mathrm{s}}$, steady component $\left(\mathrm{W}^{-1} \mathrm{~s}^{-1}\right.$. 


\section{Statistical analysis}

The Mann-Whitney $U$ test with exact two-tailed calculation of $p$-values was used for comparison of variables between two groups (SPSS version 15.0, SPSS Inc., Chicago, IL, USA). P-values less than 0.05 were considered statistically significant. All values are expressed as mean \pm standard deviation (SD).

\section{Results}

Demographic data (Table 1) and parameters commonly monitored during the cardiopulmonary bypass procedure (Table 2 ) showed no significant difference between both groups.

Table 1: Demographics data.

\begin{tabular}{lcc}
\hline parameter & group 1 $(\mathrm{n}=12)$ & group 2 $(\mathrm{n}=11)$ \\
\hline age (years) & $68 \pm 12$ & $66 \pm 11$ \\
body surface area $\left(\mathrm{m}^{2}\right)$ & $2.0 \pm 0.1$ & $1.9 \pm 0.1$ \\
gender (male /female) & $11 / 1$ & $10 / 1$ \\
\hline
\end{tabular}

None of these variables are significantly different at the 0.05 level.

Table 2. Patient related characteristics of cardio-pulmonary bypass.

\begin{tabular}{|c|c|c|c|}
\hline parameter & group $1(n=12)$ & group $2(n=11)$ & $\mathrm{p}$-value \\
\hline flow $\left(1 \cdot \mathrm{min}^{-1}\right)$ & $4.9 \pm 0.2$ & $4.8 \pm 0.2$ & 0.28 \\
\hline $\mathrm{Ap}_{\mathrm{s}}(\mathrm{mmHg})$ & $92 \pm 9$ & $89 \pm 8$ & 0.46 \\
\hline$A p_{d}(m m H g)$ & $57 \pm 7$ & $58 \pm 6$ & 0.57 \\
\hline$A p_{m}(m m H g)$ & $74 \pm 6$ & $73 \pm 6$ & 0.61 \\
\hline pulse pressure $(\mathrm{mmHg})$ & $35 \pm 9$ & $32 \pm 8$ & 0.36 \\
\hline SVR (dyn's $\mathrm{cm}^{-5}$ ) & $1,102 \pm 91$ & $1,077 \pm 114$ & 0.36 \\
\hline $\mathrm{Ht}$ & $0.22 \pm 0.04$ & $0.23 \pm 0.03$ & 0.46 \\
\hline
\end{tabular}

$A p_{s}$, systolic arterial pressure; $A p_{d}$, diastolic arterial pressure; $A p_{m}$, mean arterial pressure; $S V R$, systemic vascular resistance; $\mathrm{Ht}$, hematocrit.

Figure 1 shows that the time difference (phase shift) between $Q_{\text {in }}$ and $Q_{\text {out }}$ for the Quadrox BEHMO 2000 oxygenator is nearly six times larger than that of the Capiox SX 18 oxygenator ( $60.6 \pm 35.9 \mathrm{~ms}$ versus $11.4 \pm 8.3 \mathrm{~ms}, \mathrm{p}=0.001)$. These data confirm the higher compliance of the Quadrox oxygenator, as measured in vitro.

Figure 2 shows the decline of pressure throughout the system downstream the pulsatile pump for both groups. Because of its higher hydraulic resistance, the Capiox SX18 oxygenator induced higher mean pre-oxygenator pressures $(393 \pm 18 \mathrm{mmHg}$ 
versus $325 \pm 28 \mathrm{mmHg}, \mathrm{p}<0.0001$ ). The $32 \%$ decline in mean pressure in group 1 and the $16 \%$ decline in group 2 both resulted in similar post-oxygenator mean pressure levels ( $269 \pm 12 \mathrm{mmHg}$ and $274 \pm 17 \mathrm{mmHg}$, respectively, $\mathrm{p}=0.96$ ). Noteworthy is, that another $73 \%$ decrease of mean pressure could be seen downstream the CPB tubing system, ending with comparable mean radial artery pressures in both groups (74 \pm 6 $\mathrm{mmHg}$ in group 1 versus $73 \pm 6 \mathrm{mmHg}$ in group $2, \mathrm{p}=0.61$ ).

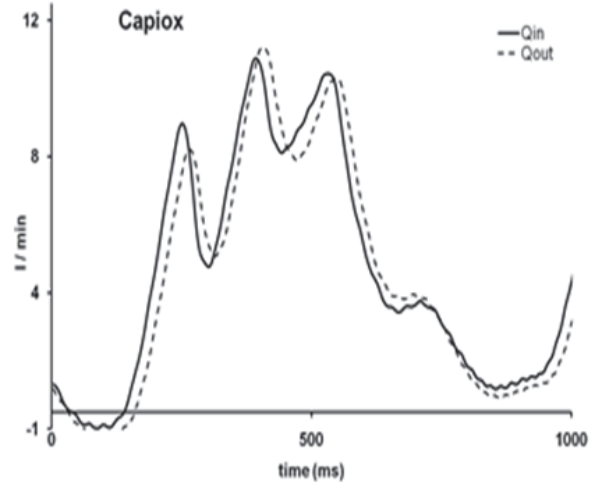

a)

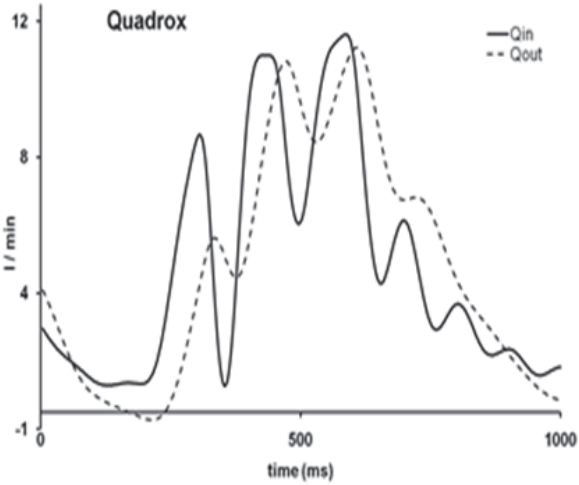

b)

Figure 1. Examples of flow before $\left(Q_{i n}\right)$ and after $\left(Q_{\text {out }}\right)$. a - Group 1 - Capiox SX 18 oxygenator; b- Group 2 Quadrox BEHMO 2000 oxygenator. The time difference between $Q_{\text {in }}$ and $Q_{\text {out }}$ (phase shift) depends from the compliance of oxygenator.

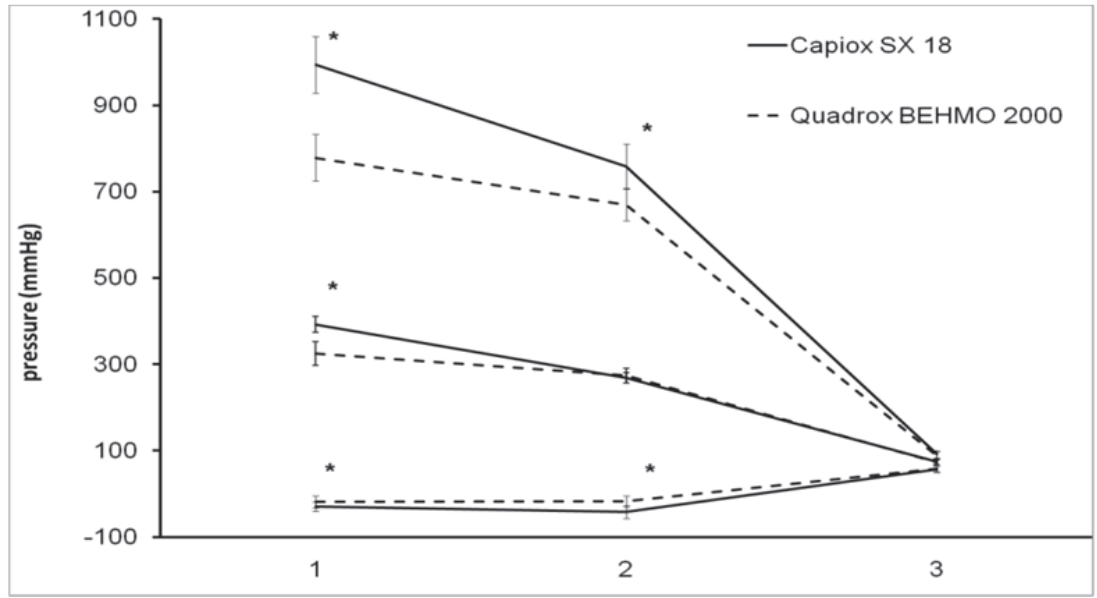

Figure 2. The maximum (upper pair of lines), mean (middle pair of lines) and minimum (lower pair of lines) pressures before (1) and after (2) the oxygenator, and in the radial artery (3). Data expressed as mean \pm SD; * difference between the groups, $\mathrm{p}<0.001$; 
The changes in flow energy in terms of EEP and SHE are presented in Table 3. Table 4 shows the dynamics of pressure energy and its components. The energy necessary to overcome the resistance of the oxygenator was significantly higher in group 1 than in group $2\left(5.7 \pm 0.5 \mathrm{~W} \mathrm{~s}^{-1}\right.$ versus $4.8 \pm 0.4 \mathrm{~W}^{-1}$, respectively, $\left.\mathrm{p}<0.0001\right)$. The reduction in EEP, $W_{t}$ and $W_{s}$ was up to two times higher when using a Capiox oxygenator. For example, in group 1 the $W_{s}$ post-oxygenator was $33 \%$ lower than the $W_{s}$ pre-oxygenator, whereas in group 2 these losses amounted to only $15 \%$. In terms of SHE and $W_{0}$, however, both groups demonstrated comparable decreases (50\% in group 1 versus $45 \%$ in group 2).

Table 3. Energy Equivalent Pressure and Surplus Hemodynamic Energy.

\begin{tabular}{llccc}
\hline & parameter & group 1 $(\mathrm{n}=12)$ & group 2 $(\mathrm{n}=11)$ & p-value \\
\hline before oxygenator & EEP $(\mathrm{mmHg})$ & $527 \pm 28$ & $452 \pm 28$ & $<0.0001$ \\
& SHE $(\mathrm{mmHg})$ & $134 \pm 12$ & $128 \pm 8$ & 0.252 \\
& FEE & $0.34 \pm 0.02$ & $0.40 \pm 0.04$ & 0.001 \\
\hline after oxygenator & EEP $(\mathrm{mmHg})$ & $337 \pm 17$ & $342 \pm 20$ & 0.691 \\
& SHE $(\mathrm{mmHg})$ & $69 \pm 6$ & $69 \pm 5$ & 1 \\
& FEE & $0.26+0.02$ & $0.25 \pm 0.02$ & 0.582 \\
\hline
\end{tabular}

EEP, energy equivalent pressure; SHE, surplus hemodynamic energy; FEE, fractional energy excess.

Table 4: The pressure energy and its components generated before and after oxygenators.

\begin{tabular}{llccc}
\hline & parameter & group 1 $(\mathrm{n}=12)$ & group 2 $(\mathrm{n}=11)$ & p-value \\
\hline before oxygenator & $\mathrm{W}_{\mathrm{t}}\left(\mathrm{W} \cdot \mathrm{s}^{-1}\right)$ & $5.7 \pm 0.5$ & $4.8 \pm 0.4$ & $<0.0001$ \\
& $\mathrm{~W}_{\mathrm{s}}\left(\mathrm{W} \mathrm{s}^{-1}\right)$ & $4.3 \pm 0.4$ & $3.5 \pm 0.3$ & $<0.0001$ \\
& $\mathrm{~W}_{\mathrm{o}}\left(\mathrm{W} \mathrm{s}^{-1}\right)$ & $1.46 \pm 0.18$ & $1.36 \pm 0.12$ & 0.207 \\
\hline after oxygenator & $\mathrm{W}_{\mathrm{t}}\left(\mathrm{W} \cdot \mathrm{s}^{-1}\right)$ & $3.6 \pm 0.3$ & $3.7 \pm 0.3$ & 0.649 \\
& $\mathrm{~W}_{\mathrm{s}}\left(\mathrm{W} \mathrm{s}^{-1}\right)$ & $2.9 \pm 0.2$ & $2.9 \pm 0.2$ & 0.608 \\
& $\mathrm{~W}_{\mathrm{o}}\left(\mathrm{W} \mathrm{s}^{-1}\right)$ & $0.73 \pm 0.09$ & $0.74 \pm 0.07$ & 0.820 \\
\hline
\end{tabular}

$W_{t}$, total pressure energy; $W_{s}$, steady component of pressure energy; $W_{0}$, oscillatory component of pressure energy.

\section{Discussion}

In the present clinical study, we evaluated the effects of two different hollow-fibre membrane oxygenators, in terms of pressure drop, pressure energy, energy equivalent pressure and surplus hemodynamic energy during normothermic CPB. Our data is in accordance with the notion that the position of the hollow-fibre oxygenator downstream of the blood pump makes the structure and hydrodynamic characteristics of 
the membrane oxygenator critically important to the quality of pulsatile flow $[14,15$, 22]. Previous studies demonstrated that the resistance of hollow-fibre oxygenators is an important property that affects the quality of pulsatility [11, 14, 15, 29]. However, despite the fact that the pressure and total energy decline was more pronounced in group 1 with a high-resistance, low-compliance oxygenator, we could not confirm previous statements that a lower pressure drop preserves pulsatility $[15,16]$. The oscillatory energy of blood flow measured downstream both oxygenators was similar in terms of SHE as well as FEE. A possible explanation for this observation can be found in earlier studies. It has been demonstrated that less compliant oxygenators allow better pulsatility in comparison to more compliant oxygenators [10, 14, 15, 17]. In our study, the static compliance of the Quadrox oxygenator was almost four times higher than that of the Capiox oxygenator. Most likely, the positive effect on pulsatility of a more than two times lower hydraulic resistance of the Quadrox compared to the Capiox is overruled by the damping effect of its four times larger compliance. Thus, despite opposite mechanical properties (low resistance and high compliance versus high resistance and low compliance), both oxygenators seem to act as comparable substantial buffers of oscillatory energy during pulsatile CPB. With almost 50\% damping of oscillatory energy by both types of oxygenator, it is difficult to disagree with the conclusion of Lim et al., who stated that gravity-flow hollow-fiber membrane oxygenators are superior for pulsatile perfusion. Such kind of oxygenators are located upstream the pulsatile pump and, therefore, do not dampen pulsatility [29].

\section{Study limitations}

The quantification of energy actually delivered to the patient's vascular bed requires recording of both flow and pressure in the aorta. In our study, however, patient hemodynamics was assessment solely by measurement of pressure in the radial artery and mean pump flow. As a result, calculation of energy delivered to the patients' vascular system was not possible. Nevertheless, a loss of $50 \%$ of oscillatory energy shows the oxygenator to be the major element in negatively affecting the quality of pulsatile flow.

\section{Conclusion}

Despite the differences in resistance and compliance of the hollow-fibre oxygenators used, both oxygenators cause a comparable loss of generated oscillatory energy. Exclusion of the oxygenator downstream the pulsatile pump would improve energy transfer during CPB. 


\section{References}

1. Likosky DS. An epidemiologist's review of the case for pulsatile flow during cardiopulmonary bypass. $J$ Extra Corpor Technol 2009; 41:30-32.

2. Grossi EA, Connolly MW, Krieger $\mathrm{KH}$, et al. Quantification of pulsatile flow during cardiopulmonary bypass to permit direct comparison of the effectiveness of various types of "pulsatile" and "nonpulsatile" flow. Surgery 1985; 98:547-554.

3. Wright G. Hemodynamic analysis could resolve the pulsatile blood flow controversy. Ann Thorac Surg 1994; 58:1199-1204.

4. Undar A. Myths and truths of pulsatile and nonpulsatile perfusion during acute and chronic cardiac support. Artif Organs 2004; 28:439-443.

5. Undar A, Rosenberg G, Myers JL. Major factors in the controversy of pulsatile versus nonpulsatile flow during acute and chronic cardiac support. ASAIO J 2005; 51:173-175.

6. Undar A, Masai T, Frazier OH, Fraser CD, Jr. Pulsatile and nonpulsatile flows can be quantified in terms of energy equivalent pressure during cardiopulmonary bypass for direct comparisons. ASAIO J 1999; 45:610-614.

7. Undar A, Eichstaedt HC, Masai T, et al. Precise quantification of pulsatility is a necessity for direct comparisons of six different pediatric heart-lung machines in a neonatal CPB model. ASAIO J 2005; 51:600-603.

8. Haines N, Wang S, Undar A, et al. Clinical outcomes of pulsatile and non-pulsatile mode of perfusion. $J$ Extra Corpor Technol 2009; 41:26-29.

9. Wright $\mathrm{G}$. The hydraulic power outputs of pulsatile and nonpulsatile cardiopulmonary bypass pumps. Perfusion 1988; 3:251-262.

10. Wright G. Factors affecting the pulsatile hydraulic power output of the Stockert roller pump. Perfusion 1989; 4:187-195.

11. Gourlay T, Taylor KM. Pulsatile flow and membrane oxygenators. Perfusion 1994; 9:189-196.

12. Rees W, Schiessler A, Schulz F, et al. Pulsatile extracorporeal circulation: fluid mechanic considerations. Perfusion 1993; 8:459-469.

13. Inzoli F, Pennati G, Mastrantonio F, Fini M. Influence of membrane oxygenators on the pulsatile flow in extracorporeal circuits: an experimental analysis. Int J Artif Organs 1997; 20:455-462.

14. Undar A, Lodge AJ, Daggett CW, et al. The type of aortic cannula and membrane oxygenator affect the pulsatile waveform morphology produced by a neonate-infant cardiopulmonary bypass system in vivo. Artif Organs 1998; 22:681-686.

15. Undar A, Koenig KM, Frazier $\mathrm{OH}$, Fraser CD, Jr. Impact of membrane oxygenators on pulsatile versus nonpulsatile perfusion in a neonatal model. Perfusion 2000; 15:111-120.

16. Wang S, Haines N, Undar A. Quantification of pressure-flow waveforms and selection of components for the pulsatile extracorporeal circuit. J Extra Corpor Technol 2009; 41:20-25.

17. Undar A, Lodge AJ, Runge TM, et al. Design and performance of a physiologic pulsatile flow neonateinfant cardiopulmonary bypass system. ASAIO J 1996; 42:M580-M583.

18. Nichols WW, O'Rourke MF. McDonald's blood flow in arteries. Theoretic, experimental and clinical principles. third ed. London: Edward Arnold.A division of Hodder \& Stoughton, 1990.

19. Shepard RB, Simpson DC, Sharp JF. Energy equivalent pressure. Arch Surg 1966; 93:730-740.

20. Undar A. Energy equivalent pressure formula is for precise quantification of different perfusion modes. Ann Thorac Surg 2003; 76:1777-1778.

21. Undar A, Ji B, Lukic B, et al. Quantification of perfusion modes in terms of surplus hemodynamic energy levels in a simulated pediatric CPB model. ASAIO J 2006; 52:712-717. 
22. Undar A, Ji B, Lukic B, et al. Comparison of hollow-fiber membrane oxygenators with different perfusion modes during normothermic and hypothermic CPB in a simulated neonatal model. Perfusion 2006; 21:381-390.

23. Lee JJ, Lim CH, Son HS, et al. In vitro evaluation of the performance of Korean pulsatile ECLS (T-PLS) using precise quantification of pressure-flow waveforms. ASAIO J 2005; 51:604-608.

24. Ji B, Ündar A. Comparison of perfusion modes on microcirculation during acute and chronic cardiac support: is there a difference? Perfusion 2007; 22:115-119.

25. Nakayama Y, Nakanishi N, Sugimachi M, et al. Characteristics of pulmonary artery pressure waveform for differential diagnosis of chronic pulmonary thromboembolism and primary pulmonary hypertension. J Am Coll Cardiol 1997; 29:1311-1316.

26. Cay S, Cagirci G, Balbay Y, et al. Effect of aortic pulse and fractional pulse pressures on early patency of sapheneous vein grafts. Coron Artery Dis 2008; 19:435-439.

27. Milnor WR, Bergel DH, Bargainer JD. Hydraulic power associated with pulmonary blood flow and its relation to heart rate. Circ Res 1966; 19:467-480.

28. Fiore GB, Redaelli A, Guadagni G, et al. Development of a new disposable pulsatile pump for cardiopulmonary bypass: computational fluid-dynamic design and in vitro tests. ASAIO J 2002; 48:260-267.

29. $\operatorname{Lim} \mathrm{CH}$, Son HS, Lee JJ, et al. Optimization of the circuit configuration of a pulsatile ECLs: an in vivo experimental study. ASAIO J 2005; 51:609-613. 


\section{CHAPTER 5}

\section{Hydrodynamic performance and heat generation by centrifugal pumps}




\section{Abstract}

For over a century, centrifugal pumps (CP) have been used in various applications, from large industrial pumps to flow pumps for aquariums. However, the use of $C P$ as blood pumps has a rather short history. Consequently, the hydraulic performance data for a blood CP are limited. The aim of our investigation was to study the hydraulic performance and the heat generation of three commercially available CP: Bio-Medicus Bio-Pump BP80 (Medtronic), Rotaflow (Jostra Medizintechnik), and DeltaStreamTM DP2 (MEDOS Medizintechnik AQ).

The study was performed using a circuit primed with a water-glycerin mixture with a dynamic viscosity of $0.00272 \mathrm{pa} / \mathrm{s}$. Pressure-flow curves were obtained by a stepwise stagnation of the pump outlet or inlet. The temperature changes were observed using ThermaCAM SC2000 (Flir Systems).

The pumps' performance in close to clinical conditions ('operating region') was analysed in this report. The 'operating region' in the case of the BP80 is positioned around the pressure-flow curve at a pump speed of $3000 \mathrm{rpm}$. In the case of the Rotaflow, the 'operating region' was between the pump pressure-flow curves at a speed of 3000 and $4000 \mathrm{rpm}$, and the DP2 was found between 7000 and $8000 \mathrm{rpm}$.

The standard deviation of mean pressure through the pump was used to characterise the stability of the pump. In experiments with outlet stagnation, the BP80 demonstrated high negative association between flow and pressure variability $(r=-$ $0.68, p<0.001)$. In experiments with the DP2, this association was positive $(r=-0.68, p$ $<0.001$ ). All pumps demonstrated significantly higher variability of pressure in experiments with inlet stagnation in comparison to the experiments with outlet stagnation.

The rise of relative temperature in the inlet of a pump was closely related to the flow rate. The heating of fluid was more pronounced in the 'zero-flow' mode, especially in experiments with inlet stagnation.

In summary, (1) the 'zero-flow' regime, which is described in the manuals of some commercially available pumps, is the use of the pump outside the allowable operating region. It is potentially dangerous and should, therefore, never be used in clinical settings. (2) Using centrifugal pumps for kinetic-assisted venous return can only be performed safely when the negative pressure at the inlet of the pump is monitored continuously. The maximum allowable negative pressure has to be defined for each type of pump, and must be based on pump performance. 


\section{Introduction}

For over a century, centrifugal pumps (CP) have been used in various applications. The exploitation of industrial pumps is regulated by the extended set of rules and instructions based on the exact knowledge of the hydrodynamic characteristics of each specific pump. However, the use of $\mathrm{CP}$ as blood pumps has a rather short history. The majority of CP used for extracorporeal circulation (ECC) are non-metallic, volute pumps [1]. These pumps are preferred for ECC because they do not have a mechanical seal, and are considered leak proof. CP have several advantages over the roller pump. It is believed that they do not produce high pressures when tubing is temporarily obstructed or kinked, do not produce spatulated emboli from compression of the tubing, and cannot pump large gas emboli. However, as everywhere in nature, the advantages are accompanied by disadvantages. The most important disadvantages are that the pump has to operate inside a narrow area of pressure-flow curve, and it has a tendency to heat the pumped fluid [2]. The aim of our study was to evaluate the hydrodynamic performance and heat generation of some commercially available $\mathrm{CP}$ (Bio-Medicus Bio-Pump BP80, Medtronic, Rotaflow, Jostra Medizintechnik, and DeltaStreamTM DP2, MEDOS Medizintechnik AQ) in the controlled experimental condition.

\section{Materials and methods}

The study was performed using a set primed with a water-glycerin mixture with a dynamic viscosity of $0.00272 \mathrm{pa} / \mathrm{s}$, which corresponds to the viscosity of blood with an Hct of $25 \%$ (Figure 1). The speed of each pump in the study was changed stepwise (by $1000 \mathrm{rpm}$ ) from $1000 \mathrm{rpm}$ to the maximum allowed by the drive console. The flow rate was changed in steps of $1 \mathrm{~L} / \mathrm{min}$ by gradual stagnation of the pump outlet or inlet3 for each pump speed. After stabilisation, the flow, and inlet and outlet pressures were recorded by Windaq software (DtaQ Instruments, Inc). A distribution of temperature in the CP was observed by infrared camera (ThermaCAM SC2000, Flir Systems). The average relative temperatures before a pump (AR01) and at the inlet of a pump (AR02, eye of an impeller) were analysed for each pump in the study (Figure 2). The relative temperature at the base of the pump (AR03) was analysed only for the DeltaStream ${ }^{\mathrm{TM}}$ DP2, because of a persistent hot area at the base of the pump, absent in other pumps included in the study. The average relative temperature at the AR01 was used for the standardisation of findings for the different pumps. All temperatures in this study are presented as a difference between the relative temperature at the AR01 and the AR02 inside the pump. 


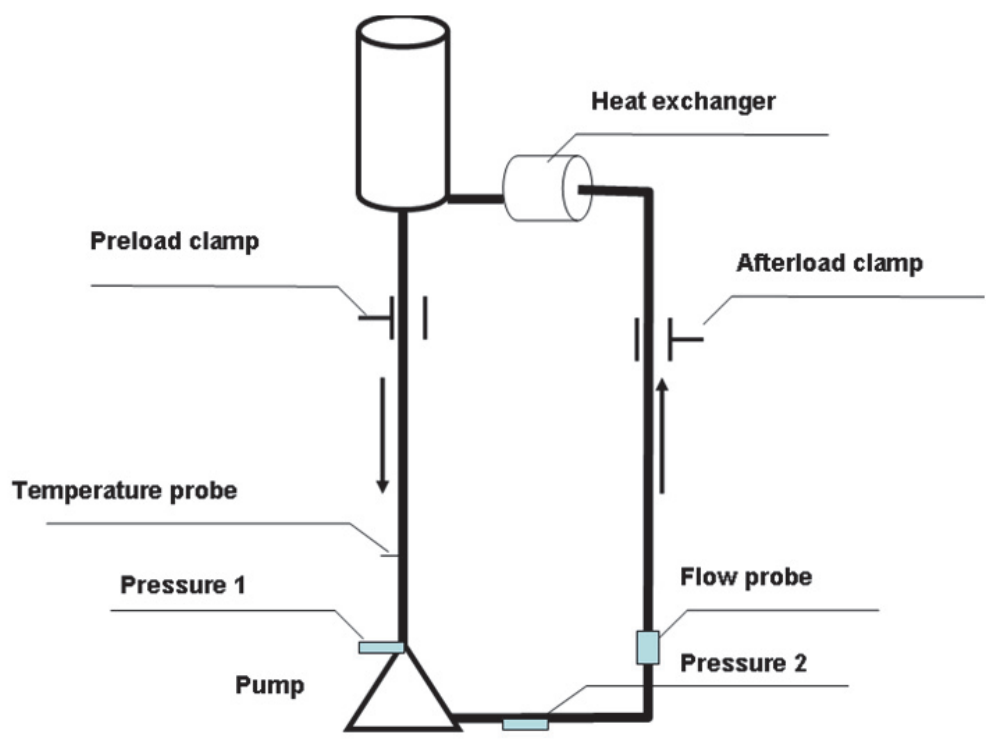

Figure 1. The circuit diagram for centrifugal pumps evaluation.
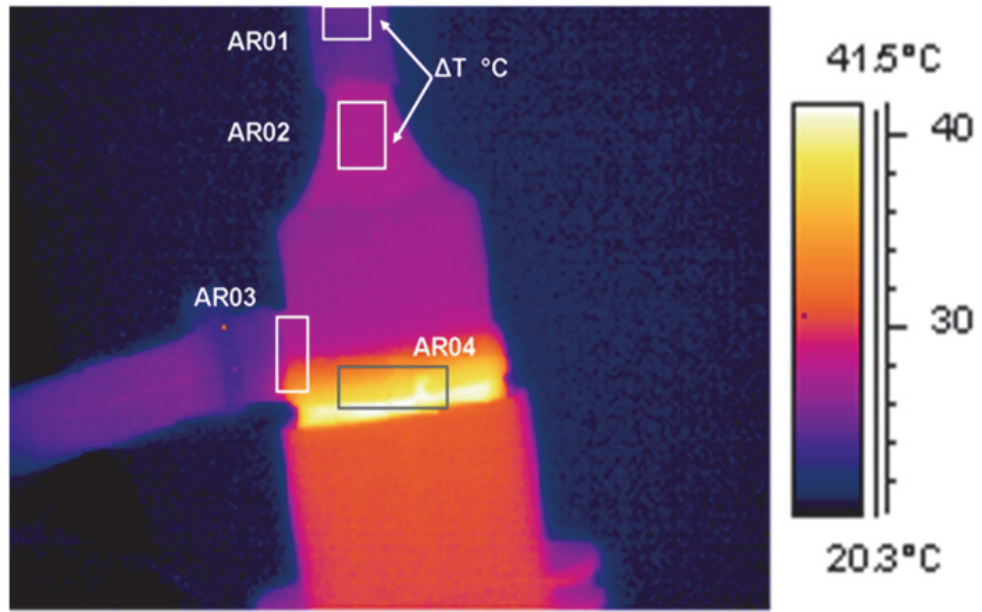

$203^{\circ} \mathrm{C}$

Figure 2. Infrared image of DeltaStream ${ }^{\mathrm{TM}} \mathrm{DP} 2$. The average relative temperatures in marked areas were taken in analysis for each pump in the study. AR01 - the area before pump. AR02 - area at the inlet of the pump (eye of an impeller). AR03 - area at the outlet of the pump. AR04 - base of the pump. ARO4 was analysed only for the DeltaStream $^{\mathrm{TM}} \mathrm{DP} 2$, because of persisted hot area at the base of the pump absent in other pumps included in the study. 


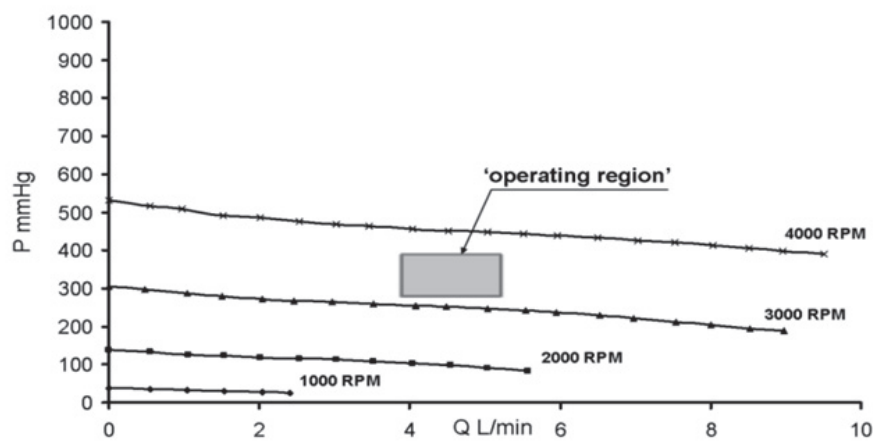

a)

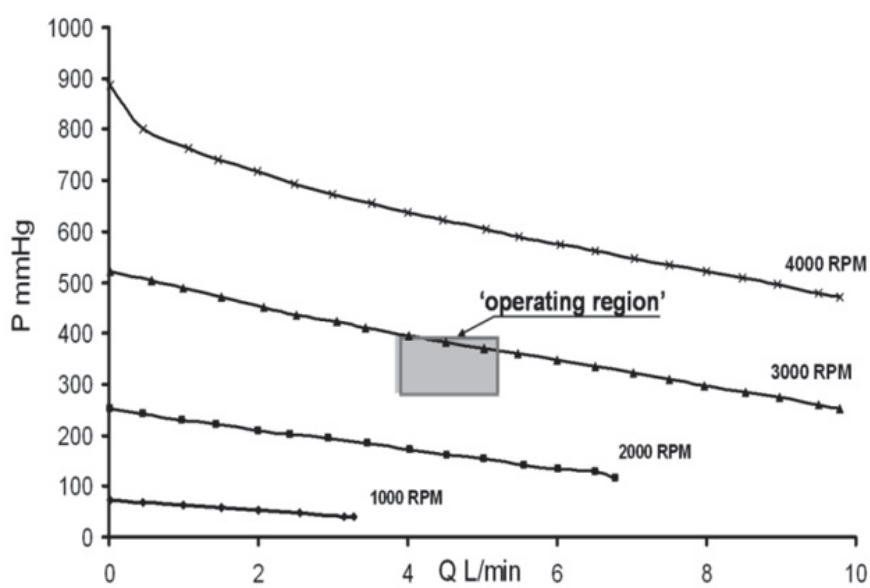

b)

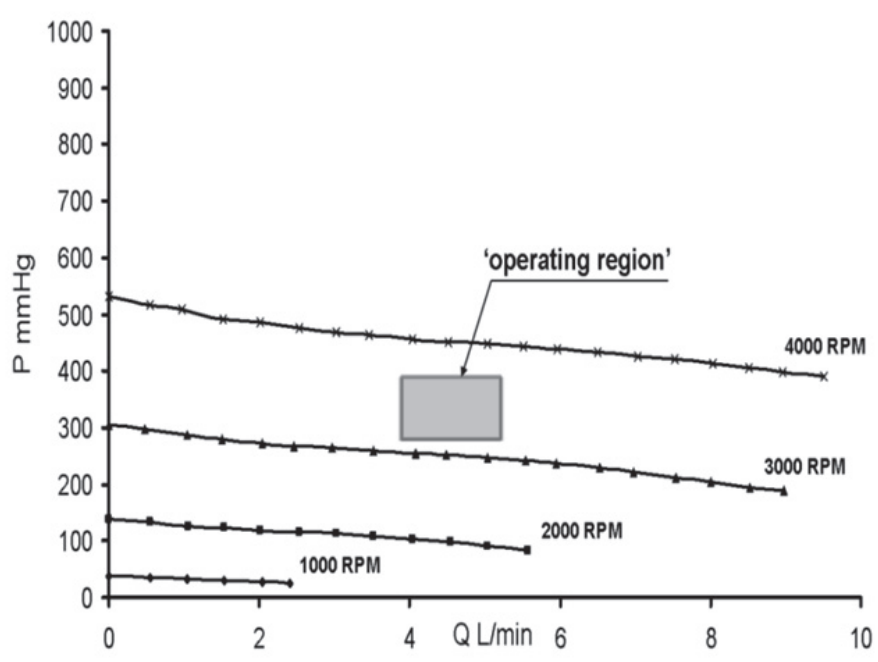

Figure 3. The pressure-flow curves and 'operating region' of centrifugal pumps. a) BioMedicus Bio-Pump BP80, Medtronic, b) Rotaflow, Jostra Medizintechnik, and c) DeltaStream $^{\text {TM }}$ DP2, MEDOS Medizintechnik AG. 
The 'operating region' was projected on the pressure flow-curves for each pump in the study. The 'operating region' was defined by the range of pre-oxygenator pressures and flows. For the set used in the University Hospital Maastricht for adult patients, the pre-oxygenator pressure was in the range of $280-390 \mathrm{mmHg}$ at flows from 3.9 to 5.2 $\mathrm{L} / \mathrm{min}$. The pumps' performance inside or close to the 'operating region' were analysed in this report. The 'operating region' in case of BP80 was positioned around the pressure-flow curve at a pump speed of $3000 \mathrm{rpm}$ (Figure 3a). In the case of a Rotaflow, the 'operating region' was between the pump pressure-flow curves at speeds of 3000 and $4000 \mathrm{rpm}$ (Figure 3b), and for DP2 it was found to be between 7000 and $8000 \mathrm{rpm}$ (Figure 3c). All data are presented as mean \pm standard deviation of the mean. One-way ANOVA procedure was used for the comparison of mean values. Pearson's correlation coefficient was used to measure an association between temperature changes and hydrodynamic data. $A \mathrm{p}$ value $\mathrm{B} / 0.05$ was considered to indicate statistical significance.

\section{Results}

The pressure-flow curves for each pump in the study are presented in Figure 3 . The shut-off pressure (i.e. pressure developed by a pump at complete outlet occlusion) for the BP80 at $3000 \mathrm{rpm}$ was $547.69 \pm 12.7 \mathrm{mmHg}$. This value was significantly higher than the shut-off pressure for the Rotaflow at $3000 \mathrm{rpm}(333.59 \pm 1.3 \mathrm{mmHg}$, $\mathrm{p}<0.001)$, and the DP2 at a pump speed of $7000 \mathrm{rpm}(360.89 \pm 2.8 \mathrm{mmHg}, \mathrm{p}<0.01)$. In experiments with inlet stagnation, the BP80, at a pump speed of $3000 \mathrm{rpm}$, the inlet pressure decreased to $-517.49 \pm 8.7 \mathrm{mmHg}$. With similar conditions, the RTF and DP2 demonstrated significantly less negative pressure at the inlet of the pump $(-284.39 \pm$ 1.9 and $266.99 \pm 109.4 \mathrm{mmHg}$, respectively, $p<0.01$ in comparison to the BP80). The standard deviation of mean pressure through the pump was used to characterise the stability of the pump (Figure 4). In the case of the BP80, at a pump speed of $3000 \mathrm{rpm}$, the mean value of the pressure standard deviation was $3.39 \pm 1.5 \mathrm{mmHg}$. The Rotaflow had a significantly more stable flow at this condition $(1.59 \pm 0.4 \mathrm{mmHg}, \mathrm{p}<0.001)$. The DP2 also demonstrated a lower variability of pressure at $7000 \mathrm{rpm}$, in comparison to the BP80 (2.39 $\pm 0.4 \mathrm{mmHg}, p<0.05)$. There was no statistically significant difference in stability of pressure between the Rotaflow and the DP2. In our experiments with flows higher than $4.0 \mathrm{~L} / \mathrm{min}$, the BP80 performance was relatively stable (the standard deviation of pressure was $2.49 \pm 0.5 \mathrm{mmHg}$ ) and only with decreasing of flow (increasing of outlet stagnation) did the pump become progressively unstable (Figure 4). Pearson's correlation coefficient yielded a high negative association of pressure variability and flow for the BP80 $(r=-0.68, p<0.001)$. DP2 pumps also demonstrated 
the dependence of the pump's stability from the flow. However, this dependence was positive $(r=0.68, p<0.001)$. If at flows $<3 \mathrm{~L} / \mathrm{min}$ the average standard deviation of the developed pressures was $1.89 \pm 0.1 \mathrm{mmHg}$, this parameter significantly rose to $2.29 \pm$ $0.1 \mathrm{mmHg}(\mathrm{p}<0.01)$ at flows $>3.5 \mathrm{~L} / \mathrm{min}$, and reached $2.79 \pm 0.3 \mathrm{mmHg}$ at flows $>4$ $\mathrm{L} / \mathrm{min}$. In the case of the Rotaflow, we failed to determine any association of pressure variability and flow ( $r=0.21, \mathrm{p}>0.05)$.

During experiments with gradual inlet stagnation, all pumps showed the same trends as in experiments with outlet stagnation (Figure 5). However, in these experiments, variability of developed pressure was significantly higher than during the outlet stagnation (Table 1).

Table 1. Variability of pressure developed by centrifugal pumps.

\begin{tabular}{lccc}
\hline \multirow{2}{*}{ Pump } & \multicolumn{2}{c}{ Pressure variability (SD) $\mathrm{mmHg}$} & $\mathrm{P}<$ \\
\cline { 2 - 3 } & Outlet stagnation & Inlet stagnation & \\
\hline BP80 at 3000 RPM & $3.3 \pm 1.5$ & $4.9 \pm 1.6$ & 0.002 \\
Rotaflow & $1.5 \pm 0.4$ & $2.1 \pm 0.8$ & 0.008 \\
DP2 & $2.3 \pm 0.4$ & $4.6 \pm 1.6$ & 0.0001 \\
\hline
\end{tabular}

All pumps demonstrated an increase of relative temperature at the inlet of the pump (Figure 6). The Rotaflow showed the highest difference in relative temperature between AR01 (before pump) and the AR02 (inlet of pump), $0.57 \pm / 0.21{ }^{\circ} \mathrm{C}$. The mean differences in relative temperature in the cases of the BP80 and the DP2 were significantly lower $\left(0.34 \pm 0.21\right.$ and $0.34 \pm 0.17{ }^{\circ} \mathrm{C}$, respectively). All pumps demonstrated a statistically significant association between the rise of relative temperature at the inlet of a pump and the flow rate (BP80 $R=-0.60, p<0.01$; Rotaflow $r=-0.59, p<0.05$; DP2 $r=-0.49, p<0.05)$. However, only in experiments with the BP80 did we find an association between the rise of relative temperature and variability of pressure through the pump $(r=0.90, p<0.0001)$.

In experiments with entire flow stagnation ('zero-flow regime'), all pumps showed rapid rising of temperature difference in 90 s on $2-4{ }^{\circ} \mathrm{C}$ (Figure $\left.7 a, b\right)$. The heating of the fluid was more pronounced in experiments with inlet stagnation (Figure $7 \mathrm{~b}$ ).

The hot area at the base of the DP2 (Figure 2) was an unexpected finding of our study. The relative temperature at the base of DP2 exceeded by $5.59 \pm 0.1{ }^{\circ} \mathrm{C}$ the temperature before the pump in experiments with gradual outlet stagnation. The difference reached was $14.69 \pm 1.2{ }^{\circ} \mathrm{C}$ in experiments with inlet stagnation. The temperature of this area was not related to the flow, but was highly associated with the pump speed $(r=0.91, p<0.0001)$. 


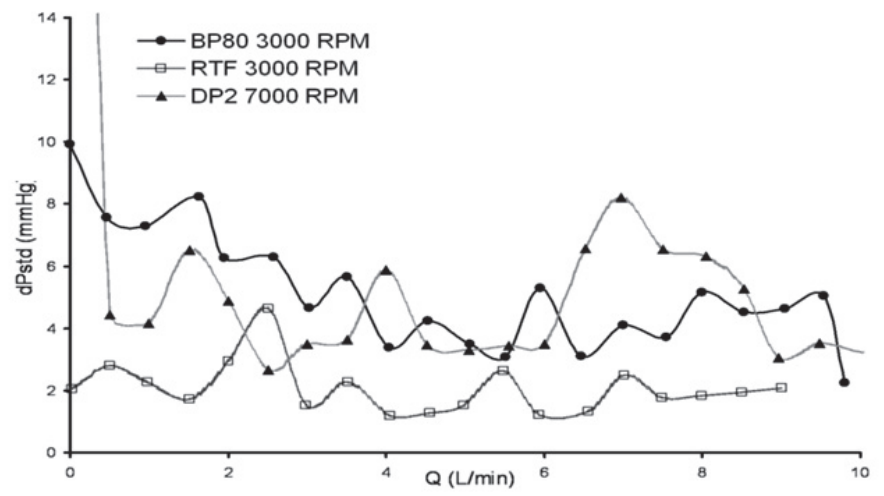

Figure 4. The standard deviation of pressure through the pumps with increasing of outlet resistance and decreasing of produced flow.

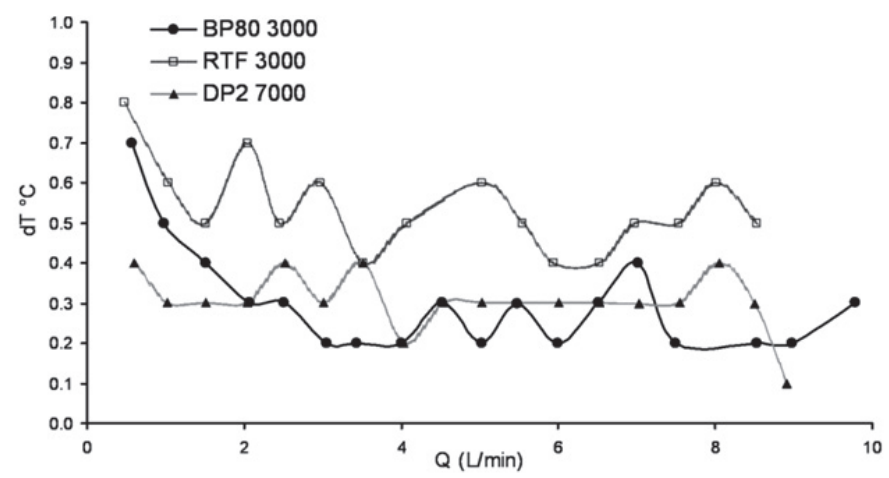

Figure 5. The standard deviation of pressure through the pumps with increasing of inlet resistance and decreasing of produced flow.

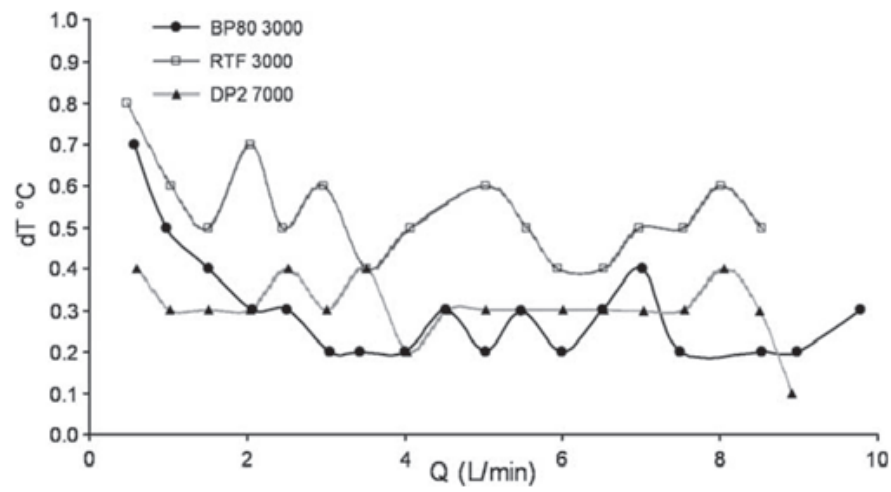

Figure 6 The difference in average of relative temperature between the AR01 (before a pump) and the AR02 (inlet of a pump) with increasing of outlet resistance and decreasing of produced flow. 
a)

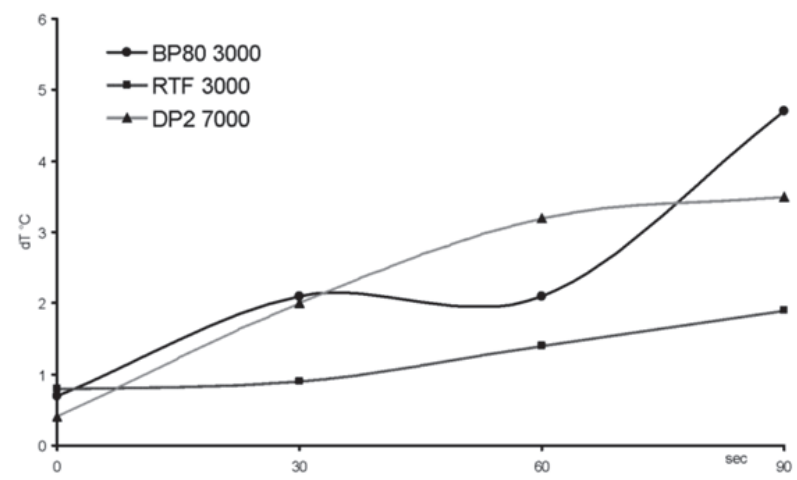

b)

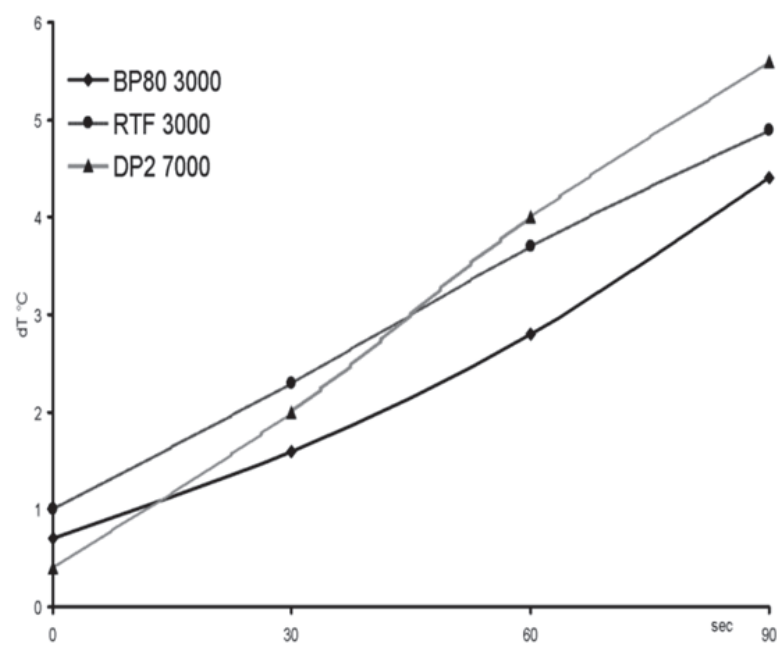

Figure 7. Average of relative temperature difference between the AR01 (before a pump) and the AR02(inlet of a pump) in 90" of a) outlet stagnation; b) inlet stagnation.

\section{Discussion}

CP were thought to be safe, harmless, and easy to operate. Apparently, this is a gross misconception. Several clinical studies are associating the use of CP with platelet destruction and hemolysis [4, 5], continuous microemboli during ECMO support [6], higher inflammatory response and neutrophil activation [5, 7]. The numerous materials dedicated to the use of industrial $\mathrm{CP}$ underline that operating of $\mathrm{CP}$ requires a great deal of knowledge and understanding of the hydrodynamics of pumps [2, 8]. Any CP has to be operated inside the so-called 'sweet zone'. 'Sweet zone' is defined as an area 
on the pump's chart where the efficiency of the pump is highest [2]. The position and size of this area depends on the pump's construction [2]. The exploitation of the pump outside the 'sweet zone' affects the pump performance. Operating the pump in the area to the right of the 'sweet zone' causes extreme turbulence and classic cavitation [2]. A positive association of pressure variability with flow $(r=0.68, p<0.001)$, and a higher variability of pressure developed by the DP2 in our experiments at flows higher than $3.5 \mathrm{~L} / \mathrm{min}$ (pump speed of $7000 \mathrm{rpm}$ ) could be explained by the shifting far to the right from the 'sweet zone'. Our data from the same experiment with the BP80 showed the opposite trend, with incensement of pressure variability with decreasing the flow rate. This fact could be explained by a shift to the left from the 'sweet zone'. If the pump operates to the left from the 'sweet zone' it is very inefficient, with excessive recirculation of fluid inside the pump and cavitation [2]. The incensement of the internal recirculation and possible cavitation could explain the positive association between the temperature rise and decreasing the flow. This process is especially pronounced in the case of the BP80, where we also found a direct relation of temperature changes with variability of pressure $(r=0.90, p<0.0001)$.

Significantly less stability of all pumps in the study, revealed in experiments with gradual inlet stagnation, could also be explained by the inherited quality of CP. With increasing the negative pressure at the inlet of pump, the situation might arise when pressure in the eye of the impeller falls lower than the vapor pressure of the liquid or saturation pressure of the gas. In this case, vaporous and gaseous cavitation can occur, and the capacity of the pump will be reduced [8]. The conditions when one or other CP starts to cavitate depend on the construction of the impeller and volute [2]. The minimum suction pressures higher than the vapor pressure are the pump's minimum requirement curve, an obligatory part of industrial pump charts. As a general guide, the pressure at the suction connection of a pump has to be at least $10 \%$ higher than indicated at the minimum requirement curve. Some experts recommend keeping suction pressure $50 \%$ higher than the minimum required to avoid incipient cavitation [2]. If, for any reason, suction pressure falls lower than the minimally required, cavitation is unavoidable. The other inherited characteristic of $C P$, especially the $C P$ we are using (volute, magnetic drive pumps), is heating up of the pumped fluid [2]. The heating of pumped fluid always takes place. During exploitation in a 'sweet zone', this rise in temperature is hardly noticeable, and a constant flow through the pump prevents over-heating. However, heat generation dramatically increases if the pump operates outside this zone. Additionally, at shut-off (zero-flow) regime, all power supplied to a CP (except for small bearing losses) goes to heating the liquid within the pump. The rate of the rise of the temperature depends on the amount of liquid contained in the casing and the power losses (shut off horsepower) of the pump. More pronounced warming of fluid in experiments with inlet occlusion could also be related 
to the extensive vapor cavitation near the eye of the impeller. The collapse of bubbles as fluid travels from the start of the impeller vane to its tip is a high-energy exothermic process. Liquid microject of collapse develops pressure $>1 \mathrm{Gpa}[2,9]$, and the temperature at the point of collapse could reach $5000 \mathrm{~K}$ [9].

We could not find an explanation for the presence of a persistent 'hot' area in the base of the DP2.

\section{Study limitations}

All temperatures in this study are presented as a difference between the relative temperature at the AR01 and AR02. The differences in thermo conductivity of materials at AR01 and AR02 could affect the values of the difference in relative temperature. However, the investigation of all pumps was carried out on the same set and at similar temperature regimes. Hence, the inherited error in deriving temperature difference(s) was the same in all experiments. That is why we believe it is correct to use these values in demonstrating the trends in warming the fluid by CP.

Our literature and experimental study demonstrated that operation of $\mathrm{CP}$ is not trouble-free and a simple process. The situation where a CP will be operated outside the allowable region could often appear during clinical perfusion. That is why the constant control of operating conditions and its comparison with a pump performance chart are absolutely necessary for the safe operation of CP.

\section{Conclusion}

(1) The 'zero-flow' regime, described in the manuals of some commercially available pumps, is the use of the pump outside the allowable operating region. It is potentially dangerous and should, therefore, never be used in clinical settings.

(2) Using CP for kinetic-assisted venous return can only be performed safely when the negative pressure at the inlet of the pump is monitored continuously. The allowable negative pressure has to be defined for each type of pump and must be based on the pump's performance.

\section{Acknowledgements}

We would like to thank WJ Smeets for help with textual processing of the manuscript. 


\section{References}

1. Leschinsky B, Itkin G, Zimin N: Centrifugal blood pumps - a brief analysis: development of new designs. Perfusion 1991; 6:115-121.

2. Bachus L, Custodio, A.: Know and Understand Centrifugal Pumps. Oxford, Elsvier, 2003.

3. Engineers ETPCotAloC: Centrifugal Pumps (Newtonian Liquids). A Guide to Performance Evaluation, Third Edition Edition Edition. New York, American Institute of Chemical Engineers, 2002.

4. Magovern GJ, Jr., Simpson KA: Extracorporeal membrane oxygenation for adult cardiac support: the Allegheny experience. Ann Thorac Surg 1999; 68:655-661.

5. Smedira NG, Moazami N, Golding CM, McCarthy PM, Apperson-Hansen C, Blackstone EH, Cosgrove DM, 3rd: Clinical experience with 202 adults receiving extracorporeal membrane oxygenation for cardiac failure: survival at five years. J Thorac Cardiovasc Surg 2001; 122:92-102.

6. Curtis JJ, Walls JT, Schmaltz RA, Demmy TL, Wagner-Mann CC, McKenney CA: Use of centrifugal pumps for postcardiotomy ventricular failure: technique and anticoagulation. Ann Thorac Surg 1996; 61:296300; discussion 311-313.

7. Baufreton $C$, Intrator $L$, Jansen $P$, te Velthuis $H$, Le Besnerais $P$, Vonk A, Farcet J, Wildevuur C, DY L: Inflammatory response to cardiopulmonary bypass using roller or centrifugal pumps. Ann Thorac Surg 1999; 67:972-977.

8. Chaurette J: Pump System Analysis and Centrifugal Pump Sizing, 5 Edition. Montreal, Fluide Design Inc., 2003.

9. Young F: Cavitation. Maidenhead, UK, McGraw-Hill Book Company, 1989. 


\section{CHAPTER 6}

\section{Can minimized cardiopulmonary bypass systems be safer?}

YM Ganushchak, EE Ševerdija, AP Simons, L van Garsse and PW Weerwind Published in Perfusion 2012 Feb; 27:176-182. 


\section{Abstract}

Although a growing body of evidence indicates superiority of minimized cardiopulmonary bypass (mCPB) systems over conventional CPB systems, limited venous return can result in severe fluctuations of venous line pressure, which can result in gaseous emboli. In this study, we investigated the influence of subatmospheric pressures and volume buffer capacity added to the venous line on the generation of gaseous emboli in the $\mathrm{MCPB}$ circuit.

Two different mCPB systems (MEC - Maquet, $n=7$ and ECC.O - Sorin, $n=8$ ) and a conventional closed cardiopulmonary bypass (cCPB) system $(n=12)$ were clinically evaluated. In search for a way to increase volume buffer capacity of mCPB systems, we additionally evaluated the 'Better Bladder' (BB) in a mock circulation by simulating repeatedly decreased venous return while measuring pressure and gaseous embolic activity.

Arterial gaseous emboli activity during clinical perfusion with a CCPB system was the lowest in comparison to the mCPB systems (312 \pm 465 versus $311 \pm 421$ with MEC and 1,966 $\pm 1,782$ with ECC.O, counts per 10 minute time interval respectively, $p=$ $0.03)$. The average volume per bubble in the arterial line was the highest in cases with cCPB $(12.5 \pm 8.3 \mathrm{~nL}$ versus $8.0 \pm 4.2 \mathrm{~nL}$ with MEC and $4.6 \pm 4.8 \mathrm{~nL}$ with ECC.O, $p=0.04$ for both). Significant cross-correlation was obtained at various time offsets from 0 to $+35 \mathrm{~s}$ between sub-atmospheric pressure in the venous line and gaseous emboli activity in both the venous and arterial line. The in vitro data showed that incorporation of the BB dampens fluctuations of venous line pressure by approximately $30 \%$ and decreases gaseous emboli by up to $85 \%$.

In conclusion, fluctuations of sub-atmospheric venous line pressure during kinetic assisted drainage are related to gaseous emboli. Volume buffer capacity added to the venous line can effectively dampen pressure fluctuations resulting from abrupt changes in venous return and, therefore, can help to increase the safety of minimized cardiopulmonary bypass by reducing gaseous microemboli formation resulting from degassing. 


\section{Introduction}

A growing body of evidence indicates the superiority of minimized cardiopulmonary bypass (mCPB) systems compared to conventional cardiopulmonary bypass (cCPB) systems, regarding inflammatory reactions and transfusion requirements. Additionally, a more complex patient population has renewed the interest in further improvement of cardiopulmonary bypass (CPB) circuits in terms of reducing priming volume and subsequent hemodilution [1-4].

Evident benefits of $\mathrm{mCPB}$ systems, however, do not come without consequences [5]. In mCPB systems, the pump flow is dependent on the venous filling [6]. The equilibrium of venous filling is a delicate one: for myocardial preservation, one needs a very limited venous filling (an empty right heart); on the other hand, for an acceptable pump flow, a certain venous filling is necessary. Moreover, venous filling is, among others, dependent on the position of the venous cannula and repositioning of the heart. So, in a mCPB system, the pump flow is directly related to the conditions of (reduced) venous return. During limited venous return, kinetic-assisted drainage, as used in these circuits, can result in severe fluctuations of venous line pressures. Some studies demonstrate that sub-atmospheric venous line pressures can cause large amounts of gaseous microemboli (GME) [7-9]. These air emboli may be sucked into the venous line at the site of cannulation. Also, there might be the introduction of GME to the circuit by degassing of blood-dissolved gasses whenever venous line pressure drops severely to sub-atmospheric levels.

Without safety mechanisms to remove or circuit modifications to handle venous air, gaseous emboli can easily travel through a mCPB system, causing a greater potential risk for continuous micro air embolization during perfusion [8, 10-14]. A bubble trap embedded in the venous line can decrease the amount of gross air entering the centrifugal pump [15-17]. Such traps are mainly intended to act as buoyancy. They prevent larger bubbles from entering the pump in which they can be milled to smaller emboli [18]. These emboli will then become suspended in the blood.

It is clear that every effort should be made to prevent air from being entrained in the venous line to decrease the risk of arterial GME. A possible way of reducing the risk of arterial GME is by reducing sub-atmospheric pressure peaks in the venous line. As described by Tamari et al., adding volume buffer capacity (i.e. 'windkessel') to the venous line by using the 'Better Bladder' can reduce pressure fluctuations at the inlet of roller or centrifugal pumps during kinetic-assisted venous drainage [19] and might, therefore, reduce patient embolic load and improve clinical neurological outcome.

The aim of this study was to investigate the influence of sub-atmospheric pressures and volume buffer capacity added to the venous line on the generation of GME in 
extracorporeal bypass circuits. The influence of sub-atmospheric pressure was perperformed clinically, whereas the effect of volume buffer capacity was tested in vitro.

\section{Materials and methods}

\section{Clinical}

Bubble counts and pressure data of patients who were routinely scheduled for elective coronary artery bypass surgery using CPB were evaluated. Perfusions were performed with three different $C P B$ circuits routinely used at our institution:

1) The first system, MEC (Figure 1), is a custom designed mCPB (Maquet Cardiopulmonary AG, Hirrlingen, Germany). This system consists of coated 3/8inch tubing (Bioline, Maquet), a centrifugal pump (Rotaflow, Maquet), and an oxygenator with integrated arterial filter (Quadrox-I BE-HM071000, Maquet). Additionally, a hard-shell venous reservoir (VHK 2001, Maquet) is connected in parallel to the venous line (Figure 1), but clamped out during perfusion. In case of an emergency, the circuit can be converted to an open system using a vacuum source. The total bypass circuit requires a priming volume of approximately 800 $\mathrm{ml}$. The needle vent is attached to the venous line and cardiotomy blood is transferred to a cell saver.

2) The Extracorporeal Circulation Optimized (ECC.O) system (Sorin Group Italia, Mirandola, Italy) is a mCPB phosphorylcholine-coated system (3/8-inch tubing) equipped with an active venous air removal device (VARD). The arterial line filter (Leukoguard-6, Pall, East Hills, NY, USA) is incorporated in the arterial line and a hard-shell venous reservoir (Dideco D970 s/v PHISIO, Sorin Group, Italy) is connected in parallel to the venous line (Figure 2), but clamped out during perfusion. As in the MEC circuit, the circuit can be converted to an open system using a vacuum source. The priming volume of this system is approximately 900 $\mathrm{ml}$. Separate roller pumps are used for the needle vent and cardiotomy suction, and blood is transferred to the cardiotomy reservoir from which it is given back to the circulation by occasionally opening the clamped reservoir outlet line.

3) The conventional closed CPB (CCPB) system (Figure 3) consists of a hollow-fibre oxygenator (Capiox SX18, Terumo Cardiovascular Systems, Tokyo, Japan), 1/2-inch venous and 3/8-inch arterial line tubing, 1/2-inch medical grade silicones arterial pump tubing, an arterial line filter (Leukoguard-6, Pall), a collapsible venous reservoir (JVR 1900, Maquet), and a cardiotomy reservoir (Capiox SX hard-shell reservoir, Terumo). This system requires approximately $1600 \mathrm{ml}$ of prime. Separate roller pumps are used for the needle vent and cardiotomy suction, and 
blood is transferred to the cardiotomy reservoir from which it is given back to the circulation.

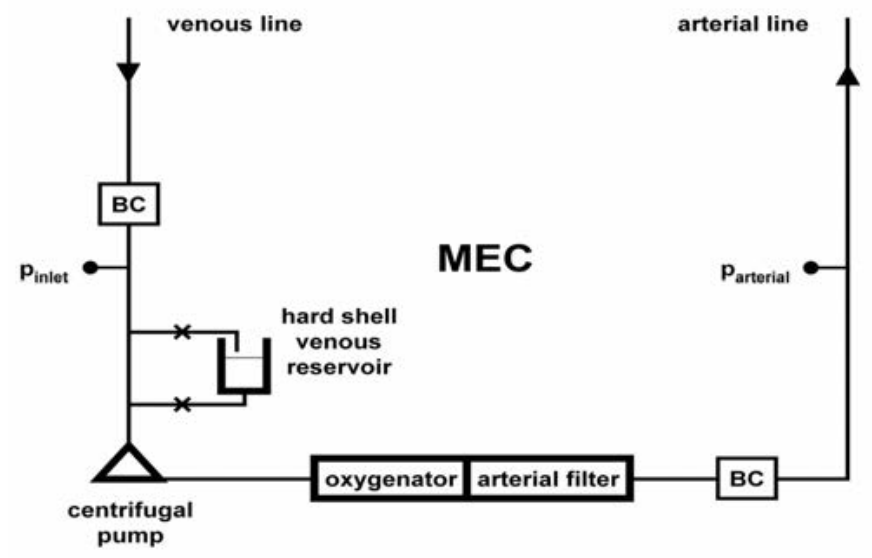

Figure 1: Minimized cardiopulmonary bypass circuit (MEC) using a centrifugal pump, oxygenator with integrated arterial filter, bubble counters (BC) and pressure measurement near the pump inlet and in the arterial line.

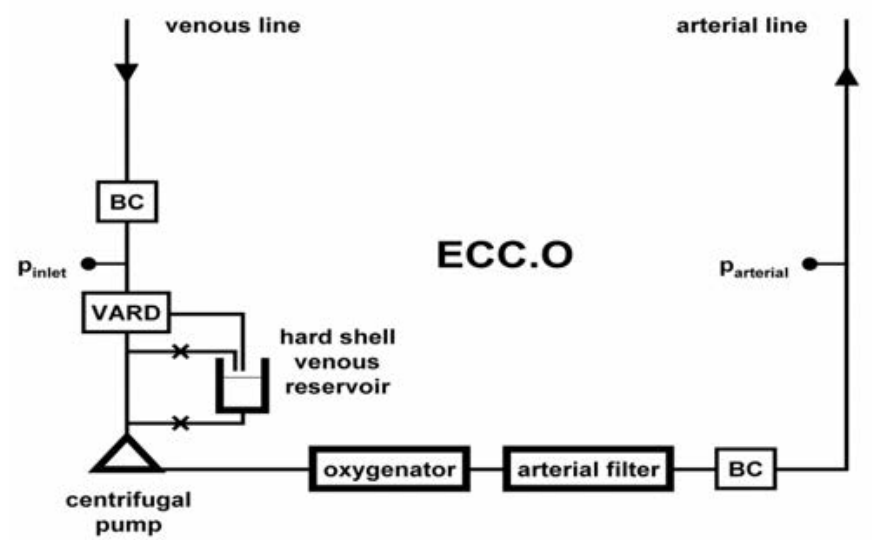

Figure 2: Minimized bypass circuit with active venous air removal device (VARD), oxygenator, arterial filter, bubble counters $(B C)$ and pressure measurement near the pump inlet and in the arterial line. 


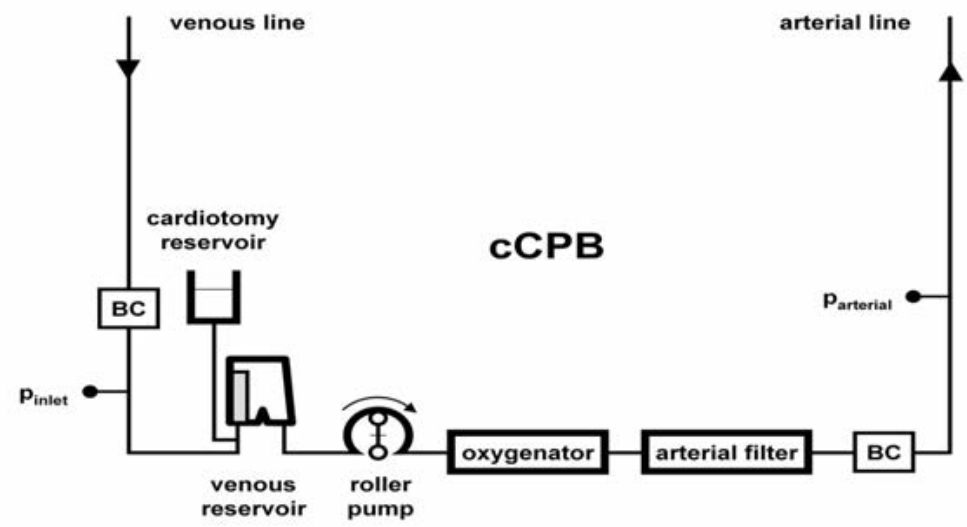

Figure 3: Conventional cardiopulmonary bypass circuit with soft-shell venous reservoir, cardiotomy reservoir, roller pump, oxygenator, arterial filter, bubble counters (BC) and pressure measurement near the inlet of the venous reservoir and in the arterial line.

A colloidal solution was used for system prime and normothermic perfusion was standardized by clinical practice. Pump flow was maintained around $2.5 \mathrm{~L} \cdot \mathrm{min} \cdot \mathrm{m}^{-2}$ to keep venous saturation in the range of $65-70 \%$. The mean arterial pressure was kept around $80 \mathrm{mmHg}$ using phenylephrine infusion, if necessary.

Microbubble activity was recorded in the venous line and in the arterial line downstream of the arterial filter at a sample frequency of $0.2 \mathrm{~Hz}$, using a bubble counting device (Bubble Counter BC200, Gampt GmbH, Zappendorf, Germany). Flow was measured at the outlet of the oxygenator using an ultrasonic clamp-on flow probe (H9XL, Transonic Systems Inc., Ithaca, NY,USA). Pressures were measured in the venous line, approximately $80 \mathrm{~cm}$ from the cannula, and at the outlet of the oxygenator, using pressure transducers (PX604, TruWave, Edwards Lifesciences, Irvine, CA, USA). Electronic data were acquired with a sampling frequency of $250 \mathrm{~Hz}$ using a programmable PC-based acquisition system (MPAQ amplifier with IDEEQ software, Instrument Development Engineering \& Evaluation, Maastricht University Medical Centre, Maastricht, the Netherlands).

\section{In vitro}

The effect of volume buffer capacity added to the venous line on the generation of sub-atmospheric pressure and GME was studied in a mock circulation of a mCPB circuit primed with $0.9 \% \mathrm{NaCl}$ solution (Figure 4). Volume buffer capacity was provided by a Better Bladder (Circulatory Technology Inc., Oyster Bay, NY, USA). The centrifugal pump flow (Rotaflow, Maquet) was set to approximately $5 \mathrm{~L} / \mathrm{min}$ with an initial 
pressure of $-80 \mathrm{mmHg}$ at the inlet side of the pump ( $\mathrm{p}_{\text {venous line }}$ ), whereas a non-occlusive single-roller roller pump (20 rpm) partially, periodically and transiently obstructed the venous line, thereby, simulating recurring short-lasting reduced venous return as it may occur in clinical minimized cardiopulmonary bypass. A hollow-fibre oxygenator was used intermittently for the elimination of gaseous bubbles from the circulation to minimize re-entering using vacuum, or to restore gaseous dissolved content in the fluid. The effect of the Better Bladder during transient reduced venous return on pressure and bubble count was evaluated by respectively opening clamp A while closing clamp B and vice versa.

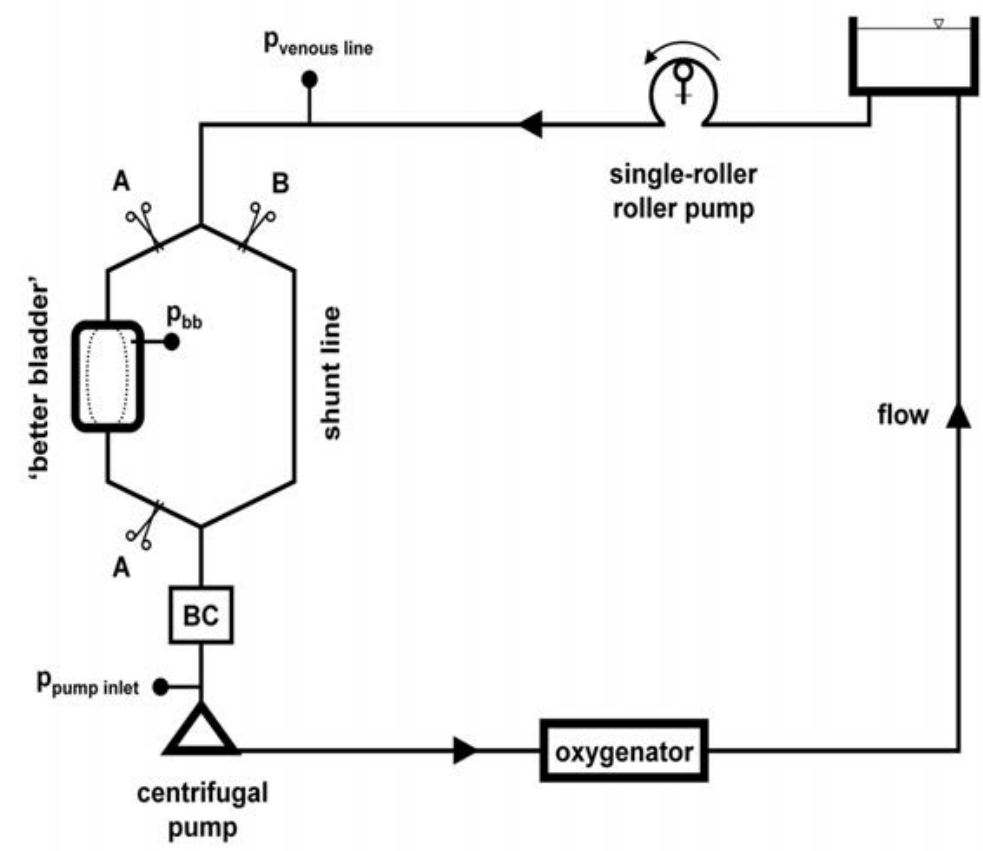

Figure 4: Mock circulation of a minimized circuit with incorporated Better Bladder, pressure measurement and bubble counters $(B C)$. The single-roller roller pump is set non-occlusive, and simulates repeatedly developing transient reduced venous return.

\section{Statistical analysis}

The ANOVA procedure was used to test the difference of mean values in groups. The relationship between venous sub-atmospheric line pressure and GME activity in both venous and arterial lines was analyzed by cross-correlation function and regression procedure (SPSS version 16.0, SPSS Inc., Chicago, IL, USA). P-values less than 0.05 were 
considered statistically significant. All values are expressed as mean \pm standard deviadeviation.

\section{Results}

\section{Clinical data}

GME activity in the arterial line during clinical perfusion with a CCPB system $(n=12)$ was the lowest in comparison to the minimized systems (312 \pm 465 with cCPB versus $311 \pm$ 421 with MEC $(n=7)$ and 1,966 $\pm 1,782$ with ECC.O $(n=8)$ cumulative counts per 10 minute time interval, respectively; $p=0.03$ ) (Figure 5). Figure 6 shows the corresponding cumulative volume of gas bubbles registered in the venous and arterial lines per $10 \mathrm{~min}$ intervals. However, the average volume per bubble in the arterial line was highest in cases with a CCPB $(12.5 \pm 8.3 \mathrm{~nL}$ versus $8.0 \pm 4.2 \mathrm{~nL}$ in MEC and $4.6 \pm 4.8$ $\mathrm{nL}$ in ECC.O; $\mathrm{p}=0.04$ for both; data not graphically displayed). Overflow bubble count, i.e. signals coming from bubbles of more than $500 \mu \mathrm{m}$ in diameter, were registered during 2 cases with MEC (28\%), 2 cases with ECC.O (25\%) and 3 cases with cCPB (25\%). In all cases, the postoperative period was uneventful.

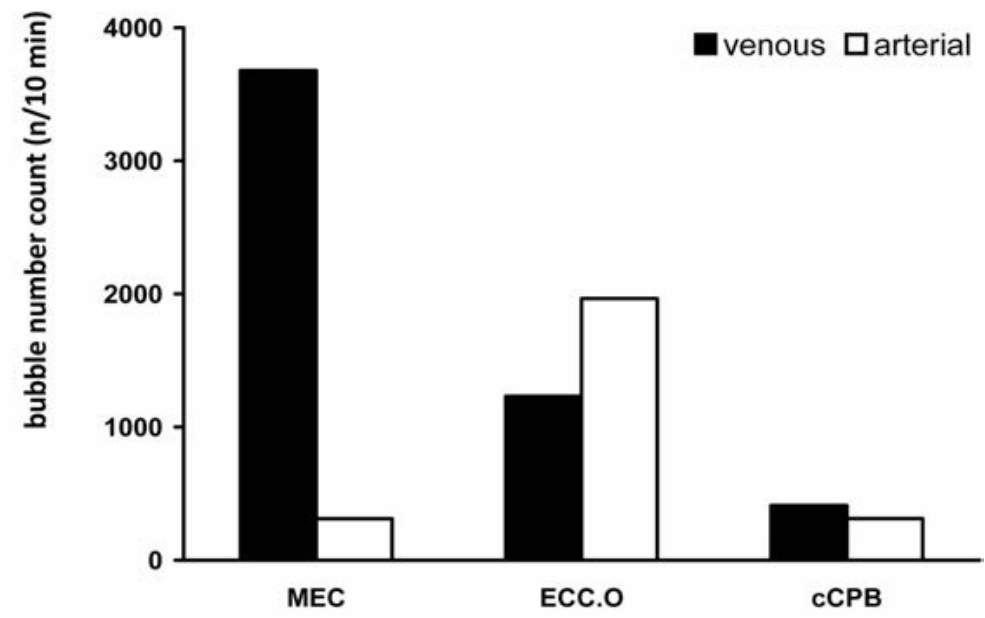

Figure 5: Cumulative number of microbubbles registered in both venous and arterial lines, per cardiopulmonary bypass circuit, per 10 minute interval. 


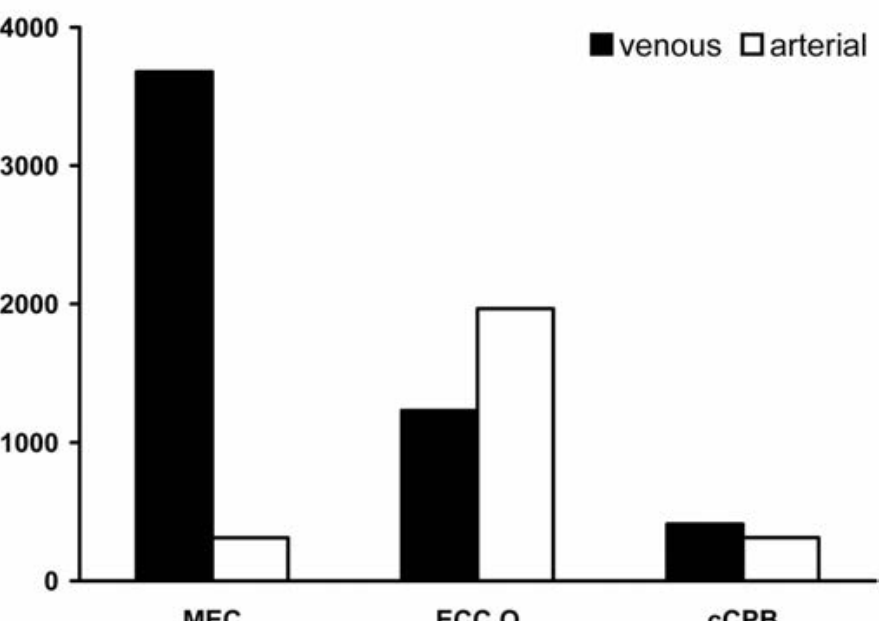

Figure 6: Cumulative volume of gas bubbles registered in venous and arterial lines, per cardiopulmonary bypass circuit, per 10 min interval.

Cross-correlation function showed a significant correlation between gas bubbles and sub-atmospheric pressure peaks in the venous line in $56 \%$ of MEC cases, in $43 \%$ of the ECC.O cases, and in one case with the CCPB system (12\%). In other words, the appearance of GME in the venous line of MEC was directly related to peaks of subatmospheric pressure. In cases with CCPB using gravity drainage, GME in the venous line cannot be explained by 'extreme' suction. The bivariate correlation procedure showed a significant correlation between sub-atmospheric pressure peaks and GME in the venous line (Pearson's correlation factor -0.35 for MEC). Much lower was this relationship in ECC.O cases (0.02) and in cases using the CCPB $(-0.06)$.

Gas bubble activity in the arterial line was significantly related to gas bubbles in the venous line (Pearson's correlation factor for $\mathrm{MEC}=0.25$; $E C C . \mathrm{O}=0.65$ ). There was no such correlation in cases of CCPB.

Table 1 shows the average venous line and venous line peak pressures during periods with and without emboli counts. Pump flow values in the three groups are comparable (Table 1). With the ECC.O system, both average venous line pressures and venous line peak pressures are higher than when using the MEC. 
Table 1: Venous line pressures and corresponding pump flows.

\begin{tabular}{lccc}
\hline & $\begin{array}{c}\text { without gas emboli } \\
\text { mean } \pm \text { SD }\end{array}$ & $\begin{array}{c}\text { with gas emboli } \\
\text { mean } \pm \text { SD }\end{array}$ & $p$ \\
\hline MEC & $\mathrm{n}=6,653$ & $\mathrm{n}=4,211$ & 0.0001 \\
venous pressure peaks (mmHg) & $-51 \pm 38$ & $-81 \pm 60$ & 0.0001 \\
venous pressure (mmHg) & $-44 \pm 33$ & $-66 \pm 48$ & 0.0001 \\
flow (L/min) & $4.0 \pm 1.4$ & $3.9 \pm 1.2$ & \\
& & & 0.0001 \\
ECC.O & $\mathrm{n}=6,977$ & $-37 \pm 48$ & 0.0001 \\
venous pressure peaks (mmHg) & $-23 \pm 46$ & $-29 \pm 42$ & 0.0001 \\
venous pressure (mmHg) & $-19 \pm 42$ & $4.3 \pm 1.0$ & \\
flow (L/min) & $4.1 \pm 1.4$ & & 0.0001 \\
cCPB system & $\mathrm{m}=1,362$ & $23 \pm 12$ & 0.0001 \\
venous pressure peaks $(\mathrm{mmHg})$ & $28 \pm 20$ & $35 \pm 10$ & 0.0001 \\
venous pressure (mmHg) & $38 \pm 19$ & $4.2 \pm 0.9$ & \\
flow (l/min) & $3.9 \pm 1.4$ & & \\
\hline
\end{tabular}

MEC, minimized cardiopulmonary bypass; ECC.O, extra corporeal circulation optimized; cCPB, conventional closed cardiopulmonary bypass; SD, standard deviation.

\section{In vitro data}

The incorporation of the BB can dampen fluctuations of the venous line pressure during transient conditions of reduced venous return in $\mathrm{mCPB}$ by approximately $30 \%$. Figure 7 shows the effect of the Better Bladder during limited venous return on venous line pressure and gaseous emboli measured in the mock circulation. By dampening, the Better Bladder decreased the number of GME by up to $85 \%$.

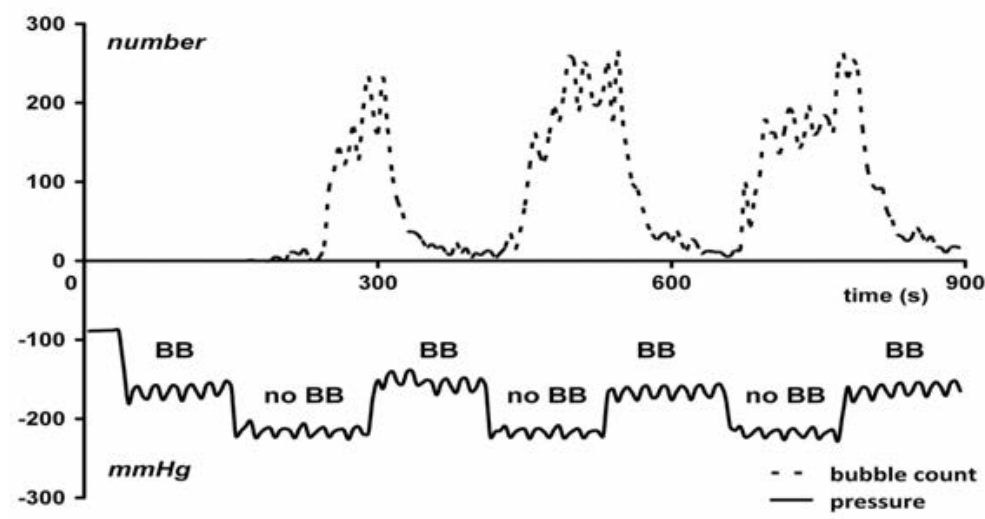

Figure 7: Venous pressure and resultant bubble count during conditions of reduced venous return with $(\mathrm{BB})$ and without (no $\mathrm{BB}$ ) Better Bladder inline the minimized bypass circuit. With the Better Bladder included, venous pressure is higher and bubble count is clearly diminished. 


\section{Discussion}

This study investigated the influence of sub-atmospheric pressures and added volume buffer capacity on the generation of gaseous microemboli (GME) in minimized cardiopulmonary bypass (mCPB) systems. Lower sub-atmospheric pressures tend to induce higher amounts of GME, whereas volume buffer capacity added to the venous line dampens fluctuations of venous line pressure and reduces GME generation.

The use of cardiopulmonary bypass (CPB) may result in the introduction of gaseous emboli into the patient's arterial circulation. These may be introduced during drug infusion via the central venous lines of the anaesthesia or via infusion into the CPB circuit itself $[20,21]$. Although decreasing venous line pressure increases the risk of air aspiration at the cannulation site, to the best of our knowledge, there is no clinical data available correlating data on GME occurrence with low venous line pressure and degassing in CPB systems. According to Henry's Law, a sudden decrease of line pressure results in gaseous bubble formation in the blood [22], as a pressure decrease disturbs the dissolved gas equilibrium. This study discusses the often underestimated, or even unknown, but present risk of bubble formation when blood is exposed to sub-atmospheric pressures.

The venous line pressures measured in the MEC group were significantly lower than to those in the ECC.O group (Table 1). This is due to the fact that the circuit and, in our cases, the pressure measurement site is located lower in relation to the patient's position when compared to the MEC system, where it is located nearly at table height. The positive pressure measured in the CCPB group can be explained by the hydrostatic column pushing on the sensor located in the venous line near the reservoir inlet. In the ECC.O group, arterial GME count and volume were higher than in the MEC and CCPB group. This can be explained by the fact that both the ECC.O and CCPB use cardiotomy suction, which can introduce bubbles into the circuit, but the CCPB features a collapsible venous reservoir that can collect bubbles. In contrast, the average arterial bubble volume was highest in the CCPB group, which can be explained by the absence of a centrifugal pump that can mill air emboli into smaller bubbles. Moreover, GME resulting from degassing are expected to be smaller, which is seen in the MEC and ECC.O groups.

GME can be quantified using bubble counting devices, commercially available for clinical application. Two common devices used are the GAMT BCC200 and the Emboli Detection and Classification quantifier (Luna Innovations, Roanoke, VA, USA) [23]. Both devices, however, show major limitations when used for studying 'worst-case' scenarios. A worst-case scenario can be a situation of embolic showers or macro air emboli conditions in which the bubble counters cannot discriminate between individual bubbles (bubble count overflow). Threshold levels, however, can vary 
between devices and results obtained by one device in a first study cannot be comcompared or exchanged with results from another device in a second study [24]. Therefore, great care should be taken when correlating measured data with neurocognitive outcome.

As mentioned before, $\mathrm{mCPB}$ systems have an increased risk of air entrainment $[25,26]$. The data in this study suggest that there is also the risk of introducing GME, even if venous blood is GME free. GME might come from degassing and could add to the explanation that some studies fail to translate the salutary effects of mCPB into clinical benefit $[5,27]$.

Bubbles found in the arterial line can have their origin in the venous line when entering the circuit at the cannulation site. With mCPB systems, some surgeons, therefore, suggest using a double purge-string suture to prevent any air from being sucked into the circulation. This double snaring, however, cannot prevent the induction of GME resulting from degassing. The degassing occurs in the venous line and inside the centrifugal pump during conditions of reduced venous return. With extreme blood loss, luxation of the heart, cannula obstruction or tube kinking, pump flow is drastically diminished and venous line pressure can transiently peak down to $-300 \mathrm{mmHg}$ or even less. Like Tamari et al., we also noticed the Better Bladder dampened pressure fluctuations (Figure 7) [19]. In addition to the reduction of sub-atmospheric peak pressures, we found a decrease in GME formation. Nevertheless, the Better Bladder remains a passive device that adds volume buffer capacity to the venous line. It does not solve the underlying mismatch of venous return and pump flow. Pump control using servo-regulation and improved venous cannula design has been proposed to optimize venous drainage [28-30]. Minimized CPB systems with Better Bladder and pump servo-regulation, combined with anti-obstructive venous cannula design, could prevent venous line pressures from peaking down to excessively low levels with concomitant GME formation, while pump speed adapts to venous drainage to maintain the maximal level of support available at that instance.

In conclusion, severe sub-atmospheric fluctuations of venous line pressure during kinetic-assisted drainage, as used in minimized cardiopulmonary bypass systems, are related to gaseous microemboli. Volume buffer capacity added to the venous line can effectively dampen pressure fluctuations resulting from abrupt changes in venous return and, therefore, can help to increase the safety of minimized cardiopulmonary bypass by reducing gaseous microemboli formation resulting from degassing.

\section{Acknowledgements}

The authors would like to acknowledge Miss Anouk A.M.A. Lindelauf for her assistance during data collection. The authors are grateful to the American Academy of 
Cardiovascular Perfusion who distinguished this work with the Best Paper Award at the 2011 Annual Academy Meeting.

\section{Funding}

This research received no specific grant from any funding agency in the public, commercial, or not-for-profit sectors.

\section{Conflict of Interest Statement}

The authors declare that there is no conflict of interest. 


\section{References}

1. Anastasiadis K, Asteriou C, Deliopoulos A, Argiriadou H, Karapanagiotidis G, Antonitsis $P$, et al. Haematological effects of minimized compared to conventional extracorporeal circulation after coronary revascularization procedures. Perfusion 2010; 25:197-203.

2. Benedetto U, Angeloni E, Refice S, Capuano F, Goracci M, Roscitano A, et al. Is minimized extracorporeal circulation effective to reduce the need for red blood cell transfusion in coronary artery bypass grafting? Meta-analysis of randomized controlled trials. J Thorac Cardiovasc Surg 2009; 138:1450-1453.

3. Vohra HA, Whistance R, Modi A, Ohri SK. The inflammatory response to miniaturised extracorporeal circulation: a review of the literature. Mediators Inflamm 2009; 2009:707042.

4. Immer FF, Ackermann A, Gygax E, Stalder M, Englberger L, Eckstein FS, et al. Minimal extracorporeal circulation is a promising technique for coronary artery bypass grafting. Ann Thorac Surg 2007; 84:1515-1520; discussion 1521.

5. Nollert G, Schwabenland I, Maktav D, Kur F, Christ F, Fraunberger P, et al. Miniaturized cardiopulmonary bypass in coronary artery bypass surgery: marginal impact on inflammation and coagulation but loss of safety margins. Ann Thorac Surg 2005; 80:2326-2332.

6. Simons AP, Reesink KD, Lance MD, van der Veen FH, de Jong DS, Weerwind PW, et al. Dynamic filling index: a novel parameter to monitor circulatory filling during minimized extracorporeal bypass. Eur $J$ Cardiothorac Surg 2009; 36:330-334.

7. Wang S, Undar A. Vacuum-assisted venous drainage and gaseous microemboli in cardiopulmonary bypass. J Extra Corpor Technol 2008; 40:249-256.

8. Lapietra A, Grossi EA, Pua BB, Esposito RA, Galloway AC, Derivaux CC, et al. Assisted venous drainage presents the risk of undetected air microembolism. J Thorac Cardiovasc Surg 2000; 120:856-862.

9. Willcox TW, Mitchell SJ, Gorman DF. Venous air in the bypass circuit: a source of arterial line emboli exacerbated by vacuum-assisted drainage. Ann Thorac Surg 1999; 68:1285-1289.

10. Norman MJ, Sistino JJ, Acsell JR. The effectiveness of low-prime cardiopulmonary bypass circuits at removing gaseous emboli. J Extra Corpor Technol 2004; 36:336-342.

11. Jones TJ, Deal DD, Vernon JC, Blackburn N, Stump DA. How effective are cardiopulmonary bypass circuits at removing gaseous microemboli? J Extra Corpor Technol 2002; 34:34-39.

12. Huybregts RM, Veerman DP, Vonk AB, Nesselaar AF, Paulus RC, Thone-Passchier DH, et al. First clinical experience with the air purge control and electrical remote-controlled tubing clamp in mini bypass. Artif Organs 2006; 30:721-724.

13. Mitsumaru A, Yozu R, Matayoshi T, Morita M, Shin H, Tsutsumi K, et al. Efficiency of an air filter at the drainage site in a closed circuit with a centrifugal blood pump: an in vitro study. ASAIO J 2001; 47:692695.

14. Morita M, Yozu R, Matayoshi T, Mitsumaru A, Shin H, Kawada S. Closed circuit cardiopulmonary bypass with centrifugal pump for open-heart surgery: new trial for air removal. Artif Organs 2000; 24:442-445.

15. Issitt RW, Mulholland JW, Oliver MD, Yarham GJ, Borra PJ, Morrison P, et al. Aortic surgery using total miniaturized cardiopulmonary bypass. Ann Thorac Surg 2008; 86:627-631.

16. Kutschka I, Schonrock U, El Essawi A, Pahari D, Anssar M, Harringer W. A new minimized perfusion circuit provides highly effective ultrasound controlled deairing. Artif Organs 2007; 31:215-220.

17. Roosenhoff TP, Stehouwer MC, De Vroege R, Butter RP, Van Boven WJ, Bruins P. Air removal efficiency of a venous bubble trap in a minimal extracorporeal circuit during coronary artery bypass grafting. Artif Organs 2010; 34:1092-1098. 
18. Rider SP, Simon LV, Rice BJ, Poulton CC. Assisted venous drainage, venous air, and gaseous microemboli transmission into the arterial line: an in-vitro study. J Extra Corpor Technol 1998; 30:160165.

19. Tamari Y, Lee-Sensiba K, Ganju R, Chan R, Hall MH. A new bladder allows kinetic venous augmentation with a roller pump. Perfusion 1999; 14:453-459.

20. Sauren L, Mooren E, Severdija E, Weerwind P, Maessen J. Emboli occurrence during coronary artery bypass surgery: the influence of a new method of perfusionist blood sampling. Perfusion 2008; 23:261-265.

21. Taylor RL, Borger MA, Weisel RD, Fedorko L, Feindel CM. Cerebral microemboli during cardiopulmonary bypass: increased emboli during perfusionist interventions. Ann Thorac Surg 1999; 68:89-93.

22. Butler BD. Gaseous Micro emboli: Concepts and Considerations. J Extra Corpor Technol 1983; 15:148155.

23. Willcox TW, Mitchell SJ. Microemboli in our bypass circuits: a contemporary audit. J Extra Corpor Technol 2009; 41:31-37.

24. De Somer FM, Vetrano MR, Van Beeck JP, Van Nooten GJ. Extracorporeal bubbles: a word of caution. Interact Cardiovasc Thorac Surg 2010; 10:995-1001.

25. Norman MJ, Sistino JJ, Acsell JR. The effectiveness of low-prime cardiopulmonary bypass circuits at removing gaseous emboli. J Extra Corpor Technol 2004; 36:336-342.

26. Murkin JM. Pulsatile versus nonpulsatile perfusion revisited. J Card Surg 2006; 21:355-356.

27. Fromes $Y$, Gaillard D, Ponzio O, Chauffert M, Gerhardt MF, Deleuze $P$, et al. Reduction of the inflammatory response following coronary bypass grafting with total minimal extracorporeal circulation. Eur J Cardiothorac Surg 2002; 22:527-533.

28. Pedersen TH, Videm V, Svennevig JL, Karlsen H, Ostbakk RW, Jensen O, et al. Extracorporeal membrane oxygenation using a centrifugal pump and a servo regulator to prevent negative inlet pressure. Ann Thorac Surg 1997; 63:1333-1339.

29. Simons AP, Reesink KD, Lance MD, van der Nagel T, van der Veen FH, Weerwind, PW, et al. Reservedriven flow control for extracorporeal life support: proof of principle. Perfusion 2010; 25:25-29.

30. Simons AP, Ganushchak Y, Wortel P, van der Nagel T, van der Veen FH, de Jong DS, et al. Laboratory performance testing of venous cannulae during inlet obstruction. Artif Organs 2008; 32:566-571. 

CHAPTER 7

General discussion 
CHAPTER 7 
This dissertation outlines the boundaries that illustrate the growth of extracorporeal life support and acknowledge frontier areas where the expertise of the clinical perfusionist is required. Because of its dual nature the nucleus of knowledge in extracorporeal technology is a synthesis of several branches of physical sciences as well as life sciences. For that, this dissertation includes examples of investigation of both sides of heart-lung machine - patient system.

Clinical studies in extracorporeal life support technology inherit not only the broad spectrum of investigation methods, but also difficulties of any clinical research. However, scientists in extracorporeal life support technology have to deal with specific obstacles, due to unique interaction between patient's body and heart-lung machine. The first obstacle in extracorporeal life support research is the selection of reference values or 'normal ranges'. Normal ranges have traditionally been defined on the basis of measurements of the "analyte" in question in a sufficiently large sample of individuals from an appropriate healthy population, in terms of age, sex, ethnicity, and other determinants [1]. Thus, perfunctory transfer of human physiology knowledge and reference values to the extracorporeal life support is erroneous simply because of mismatch of determinants.

Another obstacle is the choice of outcome measures. The choice of outcome measures is one of the most important considerations in designing clinical investigations [2]. It is recognized that clinical endpoints are the most credible characteristics used in medical studies $[2,3]$ and are the preferable outcome measures of any clinical study. In cardiovascular trials the events like death, cardiovascular death, myocardial infarction, stroke, and heart failure are natural clinical endpoints [4, 5]. However, multiple pathogenesis as well as multiple etiological nature of these complications create additional research obstacles and even can lead to a misleading conclusions.

In the study entitled "Neurological complications after coronary artery bypass grafting related to the performance of cardiopulmonary bypass" (chapter 2 ), the above named difficulties in clinical studies of extracorporeal life support were addressed. The postoperative neurological complications with clinical manifestations were chosen as an outcome measure. In other words, we sought to search for factors that solitary or in combination can be related to the early postoperative neurological disorders after an apparently normal procedure. This, as well as, understanding of the heart-lung machine-patient system as a complex of dynamically alternating relations mainly determines the method of the study. Electronic data recorded during surgery allowed to include the changes of perfusion parameters, such as pressure and flow into the analysis. Interestingly, we, as well as authors of early $[6,7]$ and more recent $[8,9]$ 
published studies, could not find the 'optimum' arterial pressure. However, defining natural groups (clusters) in the population and including the variability of perfusion parameters in the analysis made it possible to demonstrate that even apparently normal cardiopulmonary bypass (CPB) procedures affect the impact of common clinical risk factors on postoperative neurologic complications. Particularly, patients who underwent CPB procedures with large fluctuations in hemodynamic parameters showed an increased risk for the development of postoperative neurologic complications.

Despite the clear superiority of clinical endpoints as outcome measures, it is recognized that in many investigations the expected rate of clinical endpoints is low, resulting in the need for a large sample size and longitudinal follow-up to obtain adequate statistical power [5]. An alternative approach is to use indirect measures, such as biomarkers that include physical signs of disease, laboratory measures, and radiological tests, as replacement of endpoints or 'surrogates' for clinically meaningful endpoints $[2,3,10]$.

In extracorporeal life support studies, the use of surrogate endpoints is even more complicated by the absence of reference ranges for the most of adopted parameters of CPB.

One of the possible ways to get around the absence of reference ranges is used in the study presented in chapter 3 (The oxygen debt during routine cardiac surgery: illusion or reality?) of this dissertation. The aim of the study was to determine the existence and causes of oxygen debt during cardiac surgery. The challenge in study design was the absence of established values for critical oxygen delivery $\left(\mathrm{DO}_{2 \text { crit }}\right)$ during the CPB procedure, i.e. for the heart-lung machine - patient system. Furthermore, it is recognized that the value of $\mathrm{DO}_{2 \text { crit }}$ varies for different organs, clinical conditions, and pathologies [11]. Thus, it is doubtful that an universal 'good for all' $\mathrm{DO}_{2 \text { crit }}$ value can be established. The direct way of determining $\mathrm{DO}_{2 \text { crit }}$ and presence of oxygen debt is measurement of lactate and pyruvate concentration (as a biochemical substrate of anaerobic metabolism). In our study, plasma lactate and pyruvate levels did not exceed physiological ranges at rest in any patient at any study time point. In other words, using this method we failed to define the $\mathrm{DO}_{2 \text { crit }}$ value and uncover the oxygen debt during CPB in our patient population.

Another way of locating $\mathrm{DO}_{2 \text { crit }}$ in individual patients is to compare patients' actual oxygen consumption $\left(\mathrm{VO}_{2}\right)$ with their expected oxygen consumption corrected to the actual patient condition (body temperature, exclusion of heart and expends at breathing). However, this method also did not show lack of oxygen delivery during surgery and in the early postoperative period. Interestingly, by using the latter approach we revealed another than the 'oxygen debt repayment' explanation of 
'biphasic response' of reduced oxygen consumption during surgery followed by an increase of $\mathrm{VO}_{2}$ in our group of patients. A plot of actual oxygen consumption against the sample points (Figure 3 in Chapter 3) shows a 'biphasic response'. However, simple exposure of changes of body temperature and related expected oxygen consumption showed exactly the same 'biphasic' pattern. Thus, it is most likely that the 'biphasic response' is related to active cooling during CPB followed by re-warming and postoperative hyperthermia.

Our interest in $\mathrm{DO}_{2 \text { crit }}$ and $\mathrm{VO}_{2}$ as study endpoints was raised by multivariate nature of these parameters. The oxygen delivery as well as oxygen consumption represents a composite physiological function with interaction of several lower order physiological processes. These parameters can give more generalized characteristic of extracorporeal life support than hemoglobin concentration, blood flow, and oxygen content, separately. Replacing of simple, single parameters by more complex ones is becoming more popular, e.g. slowly developing changes in understanding the role of hemoglobin and/or hematocrit level in taking clinical decisions [12-15].

As a general conclusion of this part of the discussion, the opinion is confirmed of those who state that despite many advances, definitive answers and consensus on optimal practices are not realized and fundamental questions regarding the management of CPB remain unanswered $[9,16]$. However, it is clear that key attributes of optimal practice regarding management of extracorporeal life support is the careful, forthcoming balance between individual patient requirements (e.g. expected and actual oxygen consumption) and limitations in possibilities to satisfy these requirements (flow and gas exchange limitations, dilution, surgery necessities, etc.).

Presence of an artificial part in the patient-heart-lung machine system (heart-lung machine and its 'physiological block') raises more questions and problems, specific to the extracorporeal technology. There are numerous examples of such joint problems, i.e. blood-surface contact activation, systemic inflammatory response, hemolysis, anticoagulation, inhibition of fibrinolysis, microemboli and alteration of rheological characteristics of blood. Solution of these problems requires not only knowledge in respective scientific fields, but also creation of new or adaptation of previously developed methods of investigation. For instance, one of the problems and everlasting discussion can be formulated by rephrasing William Shakespeare: "to pulse, or not to pulse, that is the question". The discussion about usefulness and necessity of pulsatile flow during CPB has continued for more than half a century [17]. Noteworthy in this discussion is the fact that pulsatile CPB in clinical trials is most often characterized only by the heart-lung machine settings or by arterial pulse pressure, and not by objective quantitative measures. Lack of precise quantification of pressure and flow waveforms 
is recognized as one of the reasons for the controversy in research dealing with pulsapulsatile CPB [18-23]. Chapter 4 (The effect of oxygenator mechanical characteristics on energy transfer during clinical cardiopulmonary bypass) addresses this latter issue, using direct calculations of pressure energy (steady and oscillatory components) and related parameters (Shepard's energy equivalent pressure and surplus hemodynamic energy). These calculations allowed to precisely quantify different levels of pulsatility and energy loss through the oxygenator. Despite the difference in resistance of the evaluated oxygenators, a similar energy drop ( $\approx 50 \%)$ was observed. It is likely that further progress in search for answers in regards to necessity and feasibility of pulsatile perfusion is not only in usage of precise quantitative tags, but also in excluding the oxygenator downstream of the pulsatile device and reducing the length of the arterial line, thus integrating the circuit as much as possible.

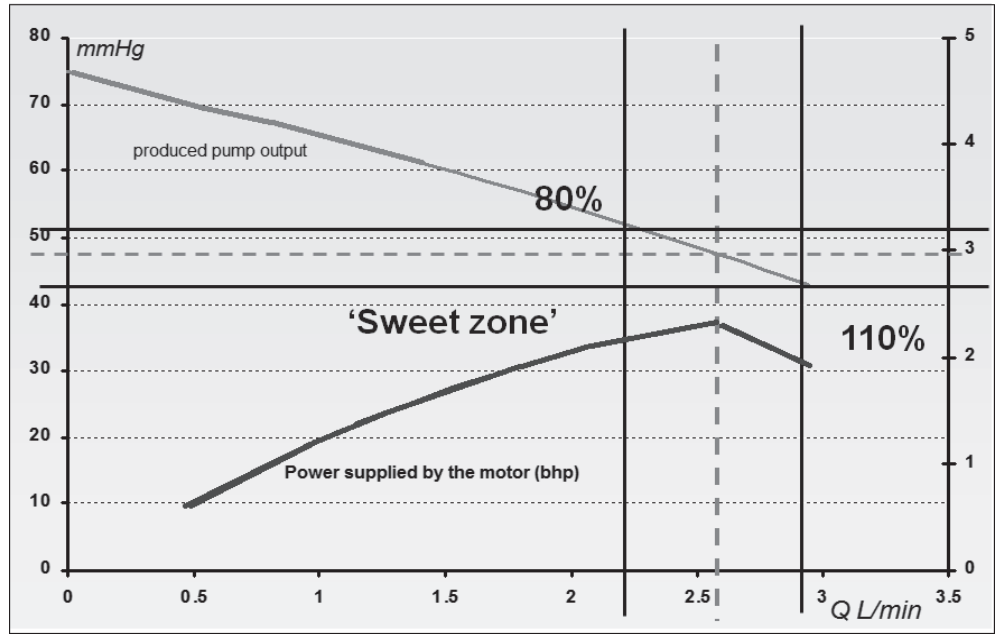

Figure 1. Best efficiency point and allowable operating region ('sweet zone') ${ }^{1}$.

Another critical part of patient-heart-lung machine system is the pump. There are two types of pumps (roller and centrifugal) independently or in combination used for CPB.

Efficiency $=\frac{\text { Useful fluid power }(P)}{\text { Power supplied by the motor }(b h p)}$

Best Efficiency Point (BEP) is the rate of flow and pressure at which the pump is most efficient. The area within $80-110 \%$ of BEP is an allowable operating region ('sweet zone') where the pump performance is optimum or close to optimum. The pump, which is operating in the zone far to the right from BEP causes extreme turbulence and classic cavitation. On the other hand, if the pump is operated far to the left from $B E P$, it is very inefficient with excessive recirculation of fluid inside the pump and cavitation. This low flow and high pressure condition causes the fluid to overheat. [Bachus, L., Custodio, A., Know and Understand Centrifugal Pumps. 2003, Oxford: Elsvier]. 
Nowadays, with development of minimized systems for CPB, usage of centrifugal pumps for routine procedures is significantly increased. Centrifugal pumps have several advantages over the roller pumps. It is believed that centrifugal pumps do not produce high pressures when tubing is temporarily obstructed or kinked, do not produce spatulated emboli from tubing compression, and cannot pump large gas emboli. Decades of usage of centrifugal pumps in combination with an open system, created a false feeling of their absolute safety and universal applicability. However, as everywhere in nature, advantages are accompanied by disadvantages. The most important but rarely realized limitations of centrifugal pumps are the narrow area of pressure-flow curve wherein the pump has to operate and its tendency to heat the pumped fluid [24]. The main goal of the study outlined in chapter 5 (Hydrodynamic performance and heat generation by centrifugal pumps) was to broaden the knowledge of concepts in regards to 'best efficiency point' and 'allowance region', or so-called 'sweet zone' (Figure 1).

Most likely that the low awareness in limitations of centrifugal pumps and their exploitation outside 'allowance region' is a cause of deleterious effects reported in the literature. Several clinical studies are associating the use of centrifugal pumps (in close systems) with platelet destruction and haemolysis [25-28], continuous microemboli[29, 30], higher inflammatory response and neutrophil activation [26, 31, 32].

Evaluation of pressure variability at diverse flow rates showed different patterns for studied pumps. The possible mechanism of pressure variability incensement is changes of flow patterns inside the pump with moving exploitation conditions to the left or right from the 'allowance region'. Suggested mechanism of pressure instability found conformation in the study by Day et al [33]. The authors reported alterations of flow pattern at both high and low flow rate conditions with appearing regions of elevated shear stress adjacent to separated or stagnant flow. In addition, dependency of power spectral density of the motor current waveform from pre- and post-load of ventricular assist devices was reported [34]. It is possible that monitoring of pressure variability could help in timely diagnostic of deviation and exploitation conditions outside the 'allowance region'. Another finding of the study presented in chapter 5, which has noteworthy clinical implications, is the significantly less stability of all pumps in experiments with gradual inlet stagnation. Increasing of the negative pressure at the pump inlet could lead to a situation where pressure in the eye of the impeller falls lower than the vapor pressure of the liquid or saturation pressure of the gas [35]. We even observed appearance of persistent gaseous microemboli downstream of the pump in these experiments [36]. Continuous monitoring of pressure at the inlet of the centrifugal pump is therefore essential for safe operating within a closed system. 
The idea of safety in exploitation of centrifugal pumps received further development in research presented in chapter 6 (Can minimized cardiopulmonary bypass systems be safer?) of this dissertation.

Development of new, smaller systems for extracorporeal life support during cardiac surgical interventions boosted a fountain of publications, in which the benefits of these systems thrust out by emphasizing one or two biomarkers. The hazard of such approach is the uncritical use of surrogate endpoints, which in history caused the needless deaths of thousands of patients [37, 38, 39]. The overenthusiasm around miniaturized systems can lead to another well-known source of bias, i.e. the selective reporting of positive and 'statistically significant' results [40]. All these create a situation in which the dangers of miniaturized systems are easily forgotten. In this unhealthy, excited atmosphere only few authors warn about hazards and loss of safety margins inherent to miniaturized systems [30, 41-44]. During limited venous return, kinetic-assisted drainage as used in these circuits can result in severe fluctuations of venous line pressures and consequently large amounts of gaseous microemboli. Without safety mechanisms to remove or circuit modification to handle venous air, gaseous emboli can easily travel through a minimized CPB system, causing a greater potential risk for continuous micro air embolization during perfusion. Results of our study are in accordance with previously reported low resistance of minimized systems to gas emboli. Gaseous emboli activity in the arterial line during clinical perfusion with a conventional CPB system was the lowest in comparison to the minimized CPB systems (Figure 5 in Chapter 6). Notable, in cases with minimized systems significant cross-correlation was obtained at various time offsets from 0 to 35 seconds between sub-atmospheric pressure in the venous line and gaseous emboli activity in both the venous and arterial line. It is clear that decreasing of pressure fluctuations in the venous line using miniaturized systems is one of the key elements in prevention of gaseous microemboli. Incorporation of a volume buffer capacity device in the venous line facilitates damping of sub-atmospheric pressure fluctuation by approximately $30 \%$ in experimental and clinical settings. Moreover, a decrease in the amount of gaseous emboli up to $85 \%$ was observed in vitro. Adding a volume buffer capacity in the venous line is an essential circuit modification, which increases stability of the CPB procedure and gas microemboli load feature for these systems.

In summary, the main subject of this interdisciplinary science can be defined as an integral heart-lung machine - patient system with unique, specific relations and reference values. Herewith optimal practice in management of extracorporeal life support is the careful, forthcoming balance between individual patient's requirements and limitations (flow and gas exchange limitations, dilution, surgery necessities, etc.). 
This statement includes two keystones of optimal practice in extracorporeal life supsupport:

- individual approach which can be formulated as "each patient is unique, each extracorporeal life support procedure must answer to dynamic changes and necessities of patient's homeostasis";

- the perfusionist must find acceptable balance between patient's requirements on the one hand and limitations during surgery, intensive therapy and resuscitation on the other hand.

With the recent success of application of extracorporeal life support in intensive therapy (H1N1 pandemic), it increasingly attracts attention and gains a more significant position in everyday clinical practice. It is very difficult to foresee how close the presented description to real structure of emerging science is, but in any case it is of the utmost importance that it is carefully preserved and passed on to the coming generation of the perfusion profession. 


\section{References}

1. Marshall WJ and Bangert SK. Clinical biochemistry: metabolic and clinical aspects. 2d ed. 2008: Elsevier Health Sciences. 984.

2. Fleming TR, Powers JH. Biomarkers and surrogate endpoints in clinical trials. Stat Med 2012; 31:29732984.

3. Biomarkers Definitions Working Group. Biomarkers and surrogate endpoints: preferred definitions and conceptual framework. Clin Pharmacol Ther 2001; 69:89-95.

4. Gheorghiade M, Adams KF Jr, Gattis WA, Teerlink JR, Orlandi C, O'Connor CM. Surrogate end points in heart failure trials. Am Heart J 2003; 145 (2 Suppl):S67-S70.

5. Domanski M, Pocock S, Bernaud C, et al. Surrogate endpoints in randomized cardiovascular clinical trials. Fundam Clin Pharmacol 2011; 25:411-413.

6. Cartwright $\mathrm{CR}$, Mangano $\mathrm{CM}$. Con: during cardiopulmonary bypass for elective coronary artery bypass grafting, perfusion pressure should not routinely be greater than $70 \mathrm{mmHg}$. J Cardiothorac Vasc Anesth 1998; 12:361-364.

7. Hartman G. Pro: during cardiopulmonary bypass for elective coronary artery bypass grafting, perfusion pressure should routinely be greater than $70 \mathrm{mmHg}$. J Cardiothorac Vasc Anesth 1998; 12:358-360.

8. Murphy GS, Hessel EA 2nd, Groom RC. Optimal perfusion during cardiopulmonary bypass: an evidence-based approach. Anesth Analg 2009; 108:1394-1417.

9. Poullis M, Palmer K, Al-Rawi O, Johson I, Ridgeway T. Pressure and oxygen debt on bypass - potential quality markers of perfusion? Perfusion 2012; 27:244-248.

10. Kawut SM, Palevsky HI. Surrogate end points for pulmonary arterial hypertension. Am Heart J 2004; 148:559-565.

11. Ranucci M. Perioperative renal failure: hypoperfusion during cardiopulmonary bypass? Semin Cardiothorac Vasc Anesth 2007; 11:265-268.

12. Spahn DR, Madjdpour C. Physiologic transfusion triggers: do we have to use (our) brain? Anesthesiology 2006; 104:905-906.

13. Ranucci M, Aronson S, Dietrich W, et al. Patient blood management during cardiac surgery: do we have enough evidence for clinical practice? J Thorac Cardiovasc Surg 2011; 142:249 e1-32.

14. Spahn DR, Shander A, Hofmann A, Berman MF. More on transfusion and adverse outcome: it's time to change. Anesthesiology 2011; 114:234-236.

15. Vretzakis G, Kleitsaki A, Aretha D, Karanikolas M. Management of intraoperative fluid balance and blood conservation techniques in adult cardiac surgery. Heart Surg Forum 2011; 14:E28-E39.

16. Oakes DA, Mangano CTM. Cardiopulmonary Bypass in 2009: Achieving and Circulating Best Practices. Anesth Analg 2009; 108:1368-1370.

17. Likosky DS. An epidemiologist's review of the case for pulsatile flow during cardiopulmonary bypass. $J$ Extra Corpor Technol 2009; 41:30-32.

18. Wright G. Hemodynamic analysis could resolve the pulsatile blood flow controversy. Ann Thorac Surg 1994; 58:1199-1204.

19. Undar A, Masai T, Frazier OH, Fraser CD Jr. Pulsatile and nonpulsatile flows can be quantified in terms of energy equivalent pressure during cardiopulmonary bypass for direct comparisons. ASAIO J 1999; 45:610-614.

20. Undar A. Myths and truths of pulsatile and nonpulsatile perfusion during acute and chronic cardiac support. Artif Organs 2004; 28:439-443. 
21. Undar A, Eichstaedt HC, Masai T, Bigley JE, Kunselman AR. Precise quantification of pulsatility is a necessity for direct comparisons of six different pediatric heart-lung machines in a neonatal CPB model. ASAIO J 2005; 51:600-603.

22. Undar A, Rosenberg G, Myers JL. Major factors in the controversy of pulsatile versus nonpulsatile flow during acute and chronic cardiac support. ASAIO J 2005; 51:173-175.

23. Haines N, Wang S, Undar A, Alkan T, Akcevin A. Clinical outcomes of pulsatile and non-pulsatile mode of perfusion. J Extra Corpor Technol 2009; 41:26-29.

24. Bachus L, Custodio A. Know and Understand Centrifugal Pumps. 2003, Oxford: Elsvier.

25. Magovern GJ Jr, Simpson KA. Extracorporeal membrane oxygenation for adult cardiac support: the Allegheny experience. Ann Thorac Surg 1999; 68:655-661.

26. Smedira NG, Moazami N, Golding CM, et al. Clinical experience with 202 adults receiving extracorporeal membrane oxygenation for cardiac failure: survival at five years. $J$ Thorac Cardiovasc Surg 2001; 122:92-102.

27. Byrnes J, McKamie W, Swearingen C, et al. Hemolysis during cardiac extracorporeal membrane oxygenation: a case-control comparison of roller pumps and centrifugal pumps in a pediatric population. ASAIO J 2011; 57:456-461.

28. Barrett CS, Jaggers JJ, Cook EF, et al. Outcomes of Neonates Undergoing Extracorporeal Membrane Oxygenation Support Using Centrifugal Versus Roller Blood Pumps. Ann Thorac Surg 2012; 94:16351641.

29. Curtis JJ, Walls JT, Schmaltz RA, Demmy TL, Wagner-Mann CC, McKenney CA. Use of centrifugal pumps for postcardiotomy ventricular failure: technique and anticoagulation. Ann Thorac Surg 1996; 61:296300; discussion 311-313.

30. Lapietra A, Grossi EA, Pua BB, et al. Assisted venous drainage presents the risk of undetected air microembolism. J Thorac Cardiovasc Surg 2000; 120:856-862.

31. Ashraf S, Butler J, Tian Y, et al. Inflammatory mediators in adults undergoing cardiopulmonary bypass: comparison of centrifugal and roller pumps. Ann Thorac Surg 1998; 65:480-484.

32. Baufreton C, Intrator L, Jansen PG, et al. Inflammatory response to cardiopulmonary bypass using roller or centrifugal pumps. Ann Thorac Surg 1999; 67:972-977.

33. Day SW, McDaniel JC. PIV measurements of flow in a centrifugal blood pump: steady flow. J Biomech Eng 2005; 127:244-253.

34. Ohuchi K, Kikugawa D, Takahashi K, et al. Control strategy for rotary blood pumps. Artif Organs 2001; 25:366-370.

35. Chaurette J. Pump System Analysis and Centrifugal Pump Sizing. 5 ed. 2003, Montreal: Fluide Design Inc. 110.

36. Ganushchak Y, van der Nagel T, de Jong DS. Hydraulic Performance and Heat Generation by Centrifugal Pumps, Proc FECECT 2005; June: p98.

37. Grimes DA, Schulz KF, Raymond EG. Surrogate end points in women's health research: science, protoscience, and pseudoscience. Fertility and Sterility 2010; 93:1731-1734.

38. Moore TJ. Deadly medicine : why tens of thousands of heart patients died in America's worst drug disaster. 1995, New York: Simon \& Schuster. p349.

39. Manns B, Owen WF Jr, Winkelmayer WC, Devereaux PJ, Tonelli M. Surrogate markers in clinical studies: problems solved or created? Am J Kidney Dis 2006; 48:159-166.

40. Boccia S, La Torre G, Persiani R, D'Ugo D, van Duijn CM, Ricciardi G. A critical appraisal of epidemiological studies comes from basic knowledge: a reader's guide to assess potential for biases. World J Emerg Surg 2007; 2:7.

41. Nollert G, Schwabenland I, Maktav D, et al. Miniaturized cardiopulmonary bypass in coronary artery bypass surgery: marginal impact on inflammation and coagulation but loss of safety margins. Ann Thorac Surg 2005; 80:2326-2332. 
42. Simons $A P$, Reesink KD, Lancé $M D$, et al. Dynamic filling index: a novel parameter to monitor circulatory filling during minimized extracorporeal bypass. Eur J Cardiothorac Surg 2009; 36:330-334.

43. Wang S, Undar A. Vacuum-assisted venous drainage and gaseous microemboli in cardiopulmonary bypass. J Extra Corpor Technol 2008; 40:249-256.

44. Norman MJ, Sistino JJ, Acsell JR. The effectiveness of low-prime cardiopulmonary bypass circuits at removing gaseous emboli. J Extra Corpor Technol 2004; 36:336-342. 


\section{Summary}

After two centuries of dormant development and relatively recent association with cardiac surgery followed by explosive technological progress, extracorporeal life support (ELS) has made a quantum leap especially during the last two decades. Scientific and technological progress in related areas, facilitate deepening and intensification of traditional as well as new methods and technics of ELS. Expanding areas of application and increasing accumulation of experience and knowledge, creates the necessity of formalizing of knowledge, thus giving birth to extracorporeal life technology as science.

The nucleus of knowledge in extracorporeal technology, because of its dual nature, is a synthesis of several branches of physical sciences as well as life sciences. As any science at the early stages of development, extracorporeal technology is re-using investigation methods of predecessors. With these, it inherits all difficulties of clinical studies and also brings in specific snags. First is the selection of reference values or 'normal ranges'. Coupling to a heart-lung machine simply disrupts or changes most of the mechanisms of homeostasis. Thus, perfunctory transfer human physiology knowledge and reference values to extracorporeal life support conditions are a dangerous mistake.

Another hitch, typical for all medical investigations, but much more pronounced in extracorporeal technologies studies is the choice of outcome measures. It is recognized that clinical endpoints are most credible in medical studies and are the preferable outcome measures of any clinical study. However, the multiple etiological nature of postoperative complications create additional research obstacles that can lead to misleading conclusions. Chapter 2 of this manuscript is an attempt to see the wood for the trees', and to bypass these obstacles. Defining natural groups (clusters) in a population of 1300 cases, made it possible to demonstrate that some patients with large fluctuations in hemodynamics during cardiopulmonary bypass procedure are at risk for the development of postoperative neurologic complications.

Despite the clear superiority of clinical endpoints as outcome measures, in many investigations the margins between various clinical endpoints is low, resulting in the need for a large sample size and longitudinal follow-up to obtain adequate statistical power. An alternative approach is to use indirect measures, such as biomarkers, as 
replacement of endpoints, so called 'surrogates' of clinically meaningful endpoints. Selecting and validating proper parameters as surrogates is subject of numerous medical studies. However, in extracorporeal life support studies, the selection of surrogate endpoints is even more complicated because of the absence of reference ranges for most of the adopted parameters of cardiopulmonary bypass. Chapter 3 of this manuscript is a demonstration of the use of individual expected oxygen consumption rates corrected to the actual patient condition as reference value for the assessment of actual oxygen consumption. This individualized approach showed that apparent 'dependence' of average oxygen consumption from average oxygen delivery is just an illusion and that modern cardiopulmonary bypass procedures are not associated with oxygen debt accumulation.

The presence of an artificial part in the patient-heart-lung machine system (the physical and 'physiological block') raises more problems, specific to extracorporeal technology. Solving these problems requires knowledge of physics and adaptation of previously developed methods of investigation in this area. Chapters 4 and 5 are examples of using methods and criteria of 'physical' sciences for investigations in extracorporeal life support technology. Furthermore, results of centrifugal pump evaluation (chapter 5 ) emphasize the necessity of related technological knowledge for safe exploitation of the heart-lung machine (centrifugal pumps as a part of the device). The issue of safety in using centrifugal pumps was further developed in chapter 6 . The invention and introduction in clinical practice allowing miniaturization of extracorporeal systems, is at least, in some situations, beneficial. However, the overenthusiasm around miniaturized systems creates a situation in which the dangers of these systems are easily forgotten. In case of limited venous return, kinetic-assisted drainage as used in these circuits can result in severe fluctuations of venous line pressures and consequently large amounts of gaseous microemboli. Without safety mechanisms or circuit modifications to handle venous air, gaseous emboli can easily travel through a minimized cardiopulmonary bypass system, causing a greater potential risk for continuous micro air embolization during perfusion. We demonstrated that incorporation of a volume buffer capacity device in the venous line facilitates damping of sub-atmospheric pressure fluctuation and decreases the gas microemboly load in experimental and clinical settings.

In summary, the main subject objective for extracorporeal life support technology as interdisciplinary science in itself, can be defined as the study of the integral heartlung machine - patient system with its unique and specific relations and reference values. Optimal practice in management of extracorporeal life support is the careful, balance between individual patient's requirements and procedural limitations (flow and gas exchange limitations, dilution, surgery necessities, etc). This statement includes two keystones for best practice in extracorporeal life support: 
- individual approach which can be formulated as "each patient is unique, each extracorporeal life support procedure must answer to dynamic changes and necessities of patient's homeostasis";

- the perfusionist must find acceptable balance between patient's requirements on the one hand and limitations during surgery, intensive therapy and resuscitation on the other hand.

It is very difficult to foresee how close the presented description is to a real emerging science, but it is in any case of the utmost importance that the keystones of best practice in extracorporeal life support are carefully preserved and passed on to the coming generation of the perfusionist. 



\section{Samenvatting}

Nadat de ontwikkeling twee eeuwen heeft stilgelegen en er pas relatief recent een relatie met de hartchirurgie is ontstaan, die is gevolgd door een explosieve technologische voortuitgang, heeft de extracorporeal life support (ELS) met name gedurende de afgelopen twintig jaar een reusachtige stap voorwaarts gemaakt. Wetenschappelijke en technologische vooruitgang op gerelateerde terreinen hebben een verdieping en verbetering van zowel traditionele als nieuwe methoden en technieken van ELS mogelijk gemaakt. Uitbreiding van de toepassingsgebieden en de toename van de ervaring en de kennis maken het noodzakelijk om deze kennis te formaliseren, waarmee de technologie van extracorporeal life support een wetenschap is geworden.

De kern van de kennis omtrent de extracorporele technologie is, gezien de duale aard daarvan, een synthese van verschillende takken van zowel de fysische wetenschappen als de levenswetenschappen. Zoals elke tak van wetenschap in de vroege fase van zijn ontwikkeling maakt de extracorporele technologie gebruik van de onderzoeksmethoden die reeds eerder zijn toegepast door zijn voorgangers. Hiermee komen alle problemen van klinische studies naar voren, terwijl er ook specifieke obstakels worden geïntroduceerd. De eerste hiervan is de selectie van de referentiewaarden of "normaalwaarden". Wanneer een mens aan een hartlongmachine wordt aangesloten worden de meeste mechanismen die zorgen voor de homeostase verstoord of veranderd. Het is daarom een gevaarlijke fout om routinematig de kennis omtrent de fysiologie van de mens en de referentiewaarden toe te passen onder omstandigheden van extracorporeal life support.

Een ander probleem, dat typisch is voor elk onderzoek op medisch gebied maar dat meer uitgesproken is in het geval van onderzoek op het gebied van extracorporele technologieën, is de keuze van de uitkomstmaten. Het is algemeen aanvaard dat bij medisch onderzoek klinische eindpunten het meest geloofwaardig zijn en dat dit de uitkomstmaten zijn waaraan tijdens ieder klinisch onderzoek de voorkeur aan wordt gegeven. Het feit dat postoperatieve complicaties multiple etiologieën hebben veroorzaakt extra obstakels voor het klinische onderzoek, waardoor de conclusies misleidend kunnen zijn. In hoofdstuk 2 van dit manuscript wordt een poging gedaan om "door de bomen het bos te zien" en deze obstakels te omzeilen. Door het definiëren van natuurlijke groepen (clusters) binnen een populatie van 1.300 patiënten 
is het mogelijk geworden aan te tonen dat sommige patiënten, bij wie tijdens een cardiopulmonary bypass-procedure grote fluctuaties in de hemodynamiek optreden, een risico lopen om postoperatief neurologische complicaties te ontwikkelen.

Ondanks de duidelijke superioriteit van klinische eindpunten als uitkomstmaten zijn tijdens veel onderzoeken de verschillen tussen de diverse klinische eindpunten gering, waardoor het noodzakelijk is om een grote onderzoekspopulatie te hebben en een longitudinale follow-up uit te voeren om statistisch adequaat verschillen te kunnen aantonen. Een alternatieve benadering is het gebruikmaken van indirecte uitkomstmaten, zoals biomarkers, in plaats van klinische eindpunten; dit zijn de zogenaamde "surrogaten" voor eindpunten die klinisch van belang zijn. Het selecteren en valideren van de juiste parameters als surrogaten is het onderwerp van vele medische onderzoeken. Bij het onderzoek naar extracorporeal life support is de selectie van surrogaat-eindpunten nog gecompliceerder omdat voor de meeste parameters die worden toegepast tijdens cardiopulmonary bypass geen referentiewaarden bestaan. In hoofdstuk 3 van dit manuscript wordt het gebruik beschreven van de individuele, verwachte zuurstofconsumptie, die wordt gecorrigeerd voor de feitelijke toestand van de patiënt, als referentiewaarde voor het feitelijke zuurstofverbruik. Deze geïndividualiseerde benadering laat zien dat de schijnbare "afhankelijkheid" van de gemiddelde zuurstofconsumptie van de gemiddelde zuurstofvoorziening een illusie is en dat moderne cardiopulmonary bypass-procedures niet gepaard gaan met het ontstaan van een zuurstoftekort.

De aanwezigheid van een kunstmatig onderdeel in het systeem van patiënt-enhartlongmachine (het fysische en "fysiologische blok") veroorzaakt meer problemen, die specifiek zijn voor de extracorporele technologie. Om deze problemen te kunnen oplossen is kennis van de fysica vereist en moeten eerder ontwikkelde methoden voor onderzoek op dit gebied worden aangepast. In hoofdstuk 4 en hoofdstuk 5 worden voorbeelden gegeven van het gebruik van methoden en criteria uit de fysische wetenschappen bij het onderzoek naar de technologie van extracorporeal life support. Bovendien maken de resultaten van onderzoek naar centrifugaalpompen (hoofdstuk 5) duidelijk dat voor een veilig gebruik van de hartlongmachine (waarvan een centrifugaalpomp een onderdeel is) technologische kennis op dit gebied noodzakelijk is. Het onderwerp van de veiligheid bij het gebruik van centrifugaalpompen komt nader aan de orde in hoofdstuk 6. De ontwikkeling en introductie in de klinische praktijk van geminiaturiseerde systemen voor extracorporele circulatie biedt, tenminste in een aantal omstandigheden, voordelen. Het overmatige enthousiasme voor geminiaturiseerde systemen creeërt echter een situatie waarin de gevaren van deze systemen gemakkelijk worden vergeten. In het geval van een beperkte veneuze terugvloed kan de actieve drainage zoals die in dergelijke circuits wordt toegepast leiden tot grote schommelingen van de druk in de veneuze lijn en daarmee tot de 
vorming van grote hoeveelheden gasvormige microembolieën. Zonder veiligheidsmeveiligheidsmechanismen of aanpassingen aan het circuit om lucht in het veneuze systeem te verwerken kunnen gasvormige embolieën gemakkelijk een geminimaliseerd systeem voor cardiopulmonary bypass passeren, met als gevolg een toename van het risico voor continue embolisatie van microscopische luchtbelletjes tijdens de perfusie. Wij hebben aangetoond dat het inbouwen van een apparaat voor volumebuffering in de veneuze lijn het dempen van de subatmosferische drukfluctuaties vereenvoudigt en zowel onder experimentele omstandigheden als in klinische situaties leidt tot een afname van de hoeveelheid gasvormige microembolieën.

Samengevat kan het belangrijkste doel van de extracorporeal life supporttechnologie als zelfstandige interdisciplinaire wetenschap worden gedefinieerd als het bestuderen van het integrale systeem van hartlongmachine plus patiënt met zijn unieke en specifieke relaties en referentiewaarden. Het optimale management van de extracorporeal life support vereist het handhaven van een zorgvuldige balans tussen de behoeften van de individuele patiënt en de beperkingen van de procedure (beperkingen in de stroom en uitwisseling van gassen, verdunning, eisen die samenhangen met de chirurgische procedure). Deze stelling omvat twee kernpunten van de "best practice" in extracorporeal life support:

- $\quad$ een individuele benadering, die kan worden worden omschreven als: elke patiënt is uniek, en elke extracorporeal life support-procedure moet rekening houden met dynamische veranderingen en de eisen die worden gesteld door de homeostase van de patiënt;

- de perfusionist moet een acceptabel evenwicht vinden tussen enerzijds de vereisten van de patiënt en anderzijds de beperkingen van de chirurgische procedure, de intensieve behandeling en een reanimatie.

Het is bijzonder moeilijk om te voorspellen hoe dicht de gegeven beschrijving bij een echte, zich ontwikkelende wetenschap ligt, maar het is in elk geval van het grootste belang dat het fundament van de "best practice" in extracorporeal life support zorgvuldig bewaard blijft en wordt overgedragen op de volgende generaties perfusionisten. 



\section{Резюме}

Після двох століть прихованого розвитку і відносно недавнього поєднання 3 сердцевосудинною хірургією та подальшого вибухового технічного прогресу, екстракорпоральна підтримка життя, особливо протягом останніх двох десятиліть, перетерпіла значні якісні зміни. Науково-технічний прогрес в суміжних галузях, сприяли поглибленню та інтенсифікації традиційних, та нових методів екстракорпоральної підтримки життя. Розширення областей застосування i збільшення накопичення досвіду і знань, створює необхідність формалізації знань, тобто народження технології екстракорпорального життя, як науки.

Ядро знань в екстракорпоральних технологій, в силу своєї подвійної природи, являє собою синтез декількох розділів фізичної науки, та наук про життя. Як і будь-яка наука на ранніх стадіях розвитку, екстракорпоральна технологія повторно використовує методи дослідження попередників. 3 цим, вона успадковує всі труднощі клінічних досліджень, а також привносить специфічні перешкоди. По-перше, це вибір еталонних або «нормальних» значень. Приєднання до апарату штучного кровообігу просто руйнує або змінює більшість механізмів гомеостазу. Таким чином, поверхневе використання знань фізіології людини і контрольних величин в умовах штучного кровообігу $є$ небезпечною помилкою.

Інша проблема, характерна для всіх медичних досліджень, але набагато більш виражена при дослідженнях в умовах штучного кровообігу є вибір критеріїв оцінки результату. Признається, що кінцеві клінічні результати є найбільш надійні в медичних дослідженнях і $є$ переважне мірило результатів будь-якого клінічного дослідження. Тим не менше, багатоетіологічниї характер післяопераційних ускладнень створює додаткові перешкоди досліджень, та може призвести до помилкових висновків. Глава 2 цього рукопису являє собою спробу «побачити ліс за деревами», і обійти ці перешкоди. Визначення природних груп (кластерів ) у популяції з 1300 випадків дозволило продемонструвати, що деякі пацієнти 3 великими коливаннями в гемодинаміки під час штучного кровообігу, мають підвищений ризик розвитку післяопераційних неврологічних ускладнень.

Незважаючи на явну перевагу кінцевих клінічних результатів, у багатьох дослідженнях різниця між кінцевими клінічними результатами низька, що призводить до необхідності великого розміру вибірки і подальшого поздовжнього 
спостереження до отримання адекватної статистичної потужності. Альтернативним підходом $€$ використання непрямих показників, таких як біомаркери, замість кінцевих клінічних результатів, так звані «сурогатів» клінічно значущих результатів. Вибір і перевірка відповідних параметрів в якості сурогатів $€$ предметом численних медичних досліджень. Тим не менш, в дослідженнях в сфері екстракорпоральної підтримки життя, вибір сурогатних параметрів $є$ ще більш складним завданням через відсутність загальновизнанних діапазонів для більшості параметрів кровообігу. Глава 3 цього рукопису $\epsilon$ демонстрацією використання індівідуальних очікуваних значень споживання кисню скоректованих з урахуванням фактичного стану пацієнта в якості базової величини для оцінки фактичного споживання кисню. Цей індивідуальний підхід показав, що очевидна «залежність» середнього рівня споживання кисню від середнього доставку кисню це всього лише ілюзія, та що сучасні процедури штучного кровообігу не пов'язані з накопичення кисневого боргу.

Присутність штучної частини в системі апарат штучного кровообігу-пацієнт (“фізіологічний блок”) привносить ще більше проблем, характерних для екстракорпоральної технології. Вирішення цих проблем вимагає знань з фізики та адаптацію раніше розроблених методів дослідження в цій області. В главах 4 і 5 наведені приклади використання методів і критеріїв «фізичної» науки для досліджень в екстракорпоральних технологій життєзабезпечення. Крім того, результати дослідження відцентрового насоса (глава 5) підкреслюють необхідність відповідних технологічних знань для безпечної експлуатації апарату штучного кровообігу (відцентрові насоси як складова частина пристрою). Питання про безпеку при використованні відцентрових насосів отримала подальший розвиток у главі 6. Винахід і впровадження в клінічну практику мініатюризації екстракорпоральної системи, принаймні, в деяких ситуаціях вигідно. Тим не менш, надмірне захоплення мініатюрними системами створює ситуацію, в якій небезпеки цих систем легко забуваються. У разі обмеження венозного повернення, кінетичний допоміжний дренаж що використовувається в цих системах може призвести до серйозних коливань венозного тиску в шлангу, отже, винекненню великі кількості газових мікроемболів. Без механізмів безпеки або модифікації схеми для попередження венозного повітря, газові емболи можуть легко проходити через мінімізовані системи штучного кровообігу, в результаті чого більше потенційний ризик безперервної повітряної мікроемболіі під час перфузії. Ми показали, що включення ємність об'ємного буфера в венозну лінію сприяє загасанню коливаннь нижче атмосферного тиску і зменшує навантаження газовими мікроемболами в експериментальних і клінічних умовах.

Таким чином, основна мета предмету екстракорпоральних технологій життєзабезпечення як міждисциплінарної науки, може бути визначена як 
вивчення інтегральної апарат штучного кровообігу - пацієнт системи 3 ї̈ унікальними та специфічні відносинами і еталонним значеннями. Найліпшою практикою в управлінні екстракорпоральної підтримки життя є ретельний, баланс між індивідуальним вимогам пацієнта і процедурних обмежень (обмеження кровотоку та газообміну, розбавлення, вимоги операції, і т.д.). Ця заява містить у собі дві наріжних вимоги практики екстракорпоральної підтримки життя:

- Індивідуальний підхід, який може бути сформульований як «кожен пацієнт унікальний, кожна процедура екстракорпорального забезпечення життя повинна відповідати на динамічні зміни і потреби гомеостазу пацієнта» ;

- Перфузіолог повинен знайти підходящий баланс між вимогами пацієнта 3 одного боку та обмеженнями операції, інтенсивної терапії або реанімації, 3 іншого боку.

Дуже важко передбачати, як близько намальована картина до розвитку науки, але що в жодному разі вкрай важливо, це щоб наріжні вимоги екстракорпоральної підтримки життя були ретельно збережені та передані майбутнім поколінням перфузіологів. 



\section{Acknowledgments}

'The book is finished' a cliché which was used by hundreds PhD candidates as a mark of an end of the past phase, but mostly as a note at the milestone in front of a new beginning, new horizons, endless possibilities and hopes. However, for me as a person in the last decade of his career, this manuscript was an opportunity to summarize experience, bring some structure in perception of profession and describe its possible future. Therefore, this part of the dissertation called for recollection of events and people who played a key role at the turning points of my life. There are: my father, Mikhail Ganushchak, physician, doctor of medicine, thoracic surgeon whose example of dedication, art and ability to see a person in any patient mostly formed me as a physician (and human being as such); another person, whose order more than 30 years ago made me a perfusiologist, is professor Nikolay Amosov, physician, cardiac surgeon, doctor of medicine, academic founder and then director of Institute of Cardio-vascular surgery in Kiev (Ukraine). His words "this is for you ... only $1 \%$ percent mortality, but for the family of a patient this is always $100 \%$ ", were and still are the main force of non-stop search for perfection in my profession. The next person is Dick de Jong, perfusionist, former head of the Department of Extracorporeal Technology at the University Medical Centre Maastricht. His invitation brought me to the Netherlands, gave me the possibility to work at the edge of progress in profession and gain the unique experience. Professor Jos Maessen, physician, doctor of medicine, cardiothoracic surgeon and head of the Department of Cardiothoracic Surgery at the University Medical Centre Maastricht. His patience, support and readiness to listen and discuss the most 'crazy' ideas and will to answer at 'one more question' always helped to stay with both feet on the floor, even in the most difficult situations, and continuously stimulate search for solutions and answers (as well as search for questions). Patrick Weerwind, perfusionist (perfusiologist), doctor of medicine, head of the Department of Extracorporeal Technology at the University Medical Centre Maastricht. His constant search for new methods, technologies, ability to combine experimental and clinical work and investigations, his ability to find the right people and form the team gave a tremendous boost to the motivation and climate at the department. Jos Maessen and Patrick Weerwind are the initiators of the enquiry, which resulted in this manuscript. They put enormous efforts in correction, discussion, and keeping me in frame of this thesis. It would never be finalized without interest and 
approval by the members of the approval commission, Prof. dr. W.F.F.A. Buhre, Prof. dr. J. Bělohlávek, Prof. dr. W.H. Mess, and Prof. dr. P.M.H.T. Roekaerts. Another person who helped a lot in finalizing book and organization around promotion is Lysette Liégeois-Bouvrie, secretary to Prof. dr. J.G. Maessen.

The surgeons, the people whose requirements are rather often "destabilization" factors during cardiopulmonary bypass, but this what forces to stay sharp and dynamic, forces to keep searching for the different solutions during every case. Professor Michael Jacobs, physician, doctor of medicine, vascular surgeon, director of Heart Vascular Centre at the University Medical Centre Maastricht is one of the few non-cardiothoracic surgeons who are operating with cardiopulmonary bypass. His challenging operations always require detail discussion, rigorous thinking and adaptation of heart-lung machine, extracorporeal system and perfusion technique. Gijs Geskes physician, cardio-thoracic surgeon is one of the few surgeons on my way with an artistic (master) technique of operation. The attempt to answer at his question about the effects of knowledge and experience of perfusionists at the outcome of surgery resulted in investigation which is presented as a chapter of this manuscript. Professor Bas Mochtar, physician, doctor of medicine, cardio-thoracic surgeon. The many, very interesting discussions at "philosophical" themes with professor Mochtar revitalized my interest to philosophy and thereby stimulated the appearing of this manuscript.

I cannot not forget my colleagues with whom I am spending most of the day time, (Ervin Ševerdija, Nicole Caberg, Diana van Dijk, Yvonne Bosh, Erik Körver, Nico Pijnappel, Antoine Simons, Anouk Lindelauf, Rik Hendrix).

Last but not least, my closest family, my wife Ludmila with whom I celebrated our $40^{\text {th }}$ anniversary of marriage a few months ago, and my daughter, Lesja, whose achievements made us very proud.

All these people and many others with whom I have worked, met, discussed different topics on some way determine my being, have formed the views, and helped in finalizing this dissertation.

My deepest thanks to all of you! 


\section{Curriculum vitae}

\section{Yuri Michailovich Ganushchak}

Date of birth: 19/11/1953.

\section{Education}

\section{Secondary school}

Mathematics, biology, physics, chemistry, Russin, Oekrainian, English languages and literature.

Crimean Medical Institute

Anatomy, histology, phisiology, farmacology, gynaecology and obstet, internal diseases, etc.

Kiev Institute of Physicians

Specialization in general surgery.

Kiev Institute of Thoracic Surgery and Tuberculosis

Specialization in thoracic surgery

Continuation courses etc.

Kiev Institute of Cardiovascular Surgery.

Specialization in perfusiology.

Moskow Institute of Cardiovascular Surgery

Specialization in pediatric perfusiology.

Kiev Institute of Cardiovascular Surgery

Thesis writing for Degree in Medical Science. 


\section{Employers}

Emergency Aid Hospital, Nikolaev

General surgeon

Kiev Institute of Thoracic Surgery and Tuberculosis

Specialization in thoracic surgery

Kiev Institute of Cardiovascular Surgery

Specialization in perfusiology

Kiev Institute of Cardiovascular Surgery

Physician-perfusiologist

Academisch Ziekenhuis Maastricht

Senior clinical perfusionist 


\section{Publications}

1. Amosov NM, Ganushchak lu M, Maksimenko VB, Nastenko EA, Vadnev AA. [Gas embolism in operations with artificial circulation]. Grudn Khir 1988; 1:32-36.

2. Maksimenko VB, Ganushchak lu M, Korol EA, Nastenko EA. [Gas microembolism caused by equipment for artificial circulation. Its significance, causes and prevention]. Anesteziol Reanimatol 1988; 4:9-11.

3. Knyshov GV, Shestunov AE, Ganushchak lu M, Ivasiuk VP, lakubiuk SA, Onishchenko VF. [Gas embolism of cerebral vessels in surgery with extracorporeal circulation (clinical and pathophysiological aspects)]. Grud Serdechnososudistaia Khir 1991; 5:33-35.

4. Ganushchak lu M, Jakovenko IG, Afanas'eva VD, Roitman EM. [The effect of the partial pressure of $\mathrm{O} 2$ in arterial blood on $\mathrm{O} 2$ consumption by patients during artificial circulation]. Anesteziol Reanimatol 1992; 3:14-15.

5. Knyshov G, Nastenco E, Ganuschak Y, Bazilevich R, Fapkov Y. Training programsimulator for the process of artificial circulation during open-heart operations. Revue Europeenne de technologie biomedicale 1993; 15:227.

6. Ganuschak Y. A computer program that implements a physiological model for studying the pressure-flow relation during cardiopulmonary bypass. NeSECC Journaal 1997; Aug (1):12-18.

7. Fransen EJ, Saers S, Ganushchak Y, Buurman WA, Maessen JG. Inflammatory response and myocardial tissue injury following assisted beating heart coronary artery bypass. Netherlands Heart Journal 2002; 10 (suppl 1):23.

8. Ganushchak YM, Maessen JG, de Jong DS. The oxygen debt during routine cardiac surgery: illusion or reality? Perfusion 2002; 17:167-173.

9. Jungschleger JGM, Hulst van der FF, Beekman HDM, Ganushchak YM, Maessen JG, Bakker de JM, et al. No dominant role for re-entry in the perpetuation of drug induced Torsade de Pointes arrythmias. PACE 2002; 25:627.

10. Reesink K, Dekker AL, Nagel van der T, Veen van der F, Ommen van GVA, Ganushchak $Y$, et al. New Impella intracardiac minipump supports the left heart significantly better than aortic balloon pumping. Netherlands Heart Journal 2002; 10:485.

11. Ganushchak YM, Fransen EJ, Visser C, De Jong DS, Maessen JG. Neurological complications after coronary artery bypass grafting related to the performance of cardiopulmonary bypass. Chest 2004; 125:2196-2205.

12. Fransen EJ, Ganushchak YM, Vijay V, de Jong DS, Buurman WA, Maessen JG. Evaluation of a new condensed extra-corporeal circuit for cardiac surgery: a prospective randomized clinical pilot study. Perfusion 2005; 20:91-99. 
13. Bosch YP, Ganushchak YM, de Jong DS. Comparison of ACT point-of-care measurements: repeatability and agreement. Perfusion 2006; 21:27-31.

14. Simons AP, Ganushchak $Y$, Wortel $P$, van der Nagel $T$, van der Veen FH, de Jong DS, et al. Laboratory performance testing of venous cannulae during inlet obstruction. Artif Organs 2008; 32:566-571.

15. Simons AP, Groenenberg I, Ganushchak YM, Weerwind PW. "Water leakage" in an oxygenator; a suspected unexpected phenomenon. Perfusion 2010; 25:107-108.

16. Ganushchak YM, Reesink KD, Weerwind PW, Maessen JG. The effect of oxygenator mechanical characteristics on energy transfer during clinical cardiopulmonary bypass. Perfusion 2011; 26:39-44.

17. Ganushchak YM, Severdija EE, Simons AP, van Garsse L, Weerwind PW. Can minimized cardiopulmonary bypass systems be safer? Perfusion 2012; 27:176-182.

18. Ganushchak Y, Weerwind PW, Maessen JG. A glance to the future. Perfusion 2012; 27:95-96.

19. Korver EP, Ganushchak YM, Simons AP, Donker DW, Maessen JG, Weerwind PW. Quantification of recirculation as an adjuvant to transthoracic echocardiography for optimization of dual-lumen extracorporeal life support. Intensive Care Med 2012; 38:906-909.

20. Simons AP, Ganushchak YM, Teerenstra S, Bergmans DC, Maessen JG, Weerwind PW. Hypovolemia in extracorporeal life support can lead to arterial gaseous microemboli. Artif Organs 2013; 37:276-282.

21 Simons AP, Lindelauf AAMA, Ganushchak YM, Maessen JG, Weerwind PW. Efficacy and safety of strategies to preserve stable extracorporeal life support flow during simulated hypovolemia. Perfusion 2013 In press .

\section{Patents}

Ganushchak-Y. The instrument for biopsy of soft tissues. USSR patent N 1228.838; 0801-1986.

Ganuschak-Y. The method of gas embolism prophylactic during cardiac operations with artificial circulation. USSR. Patent N 14914.63; 08-03-1989.

Ganuschak-Y. A method of treating gas embolism. USSR. Patent N 4728820/14; 26-06-89. 